\title{
DEVELOPMENT AND ENGINEERING PLAN FOR GRAPHITE SPENT FUELS CONDITIONING PROGRAM
}

\author{
C. L Bendixsen, Editor \\ D. L Fillmore \\ R. J. Kirkham \\ D. L Lord \\ M. B. Phillips \\ A. P. Pinto \\ M. D. Staiger
}

September 1993

\section{Westinghouse Idaho Nuclear Company, Inc.}

PREPARED FOR THE

DEPARTMENT OF ENERGY

IDAHO OPERATIONS OFFICE

UNDER CONTRACT DE-AC07-84ID12435

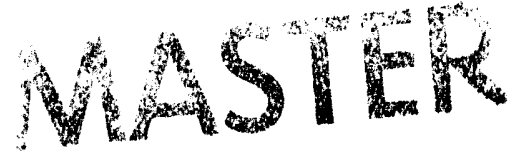


CONTENTS

ABSTRACT

iii

SUMMARY • . • . . . . . . . . . . . . . . . . . . . iv

ACRONYMS . . . . . . . . . . . . . . . . . . . V

1. OBJECTIVE . . . . . . . . . . . . . . . . 1

2. COMPARISON OF GRAPHITE FUELS . . • . . . . . . . . 6

3. OPTIONS FOR CONDITIONING FUELS . • . • • • . . . • . 11

4. DEVELOPMENT AND ENGINEERING PROGRAM . . . . . . . . . 14

4.1 DIRECT FUEL DISPOSAL • . . . . . . . . . . . . 14

4.2 MECHANICAL DISASSEMBLY . . . . . . . . . . 17

4.2.1 FUEL ELEMENT DISASSEMBLY . . . . . . . . 17

4.2.2 EMPTY BLOCK DISPOSAL . . . . . . . . 19

4.2.3 ROD DISPOSAL . . . . . . . . . . . . 24

4.3 FUEL EXAMINATION . . . . . . . . . . . . . 27

4.4 FUEL PROCESSING . . . . . . . . . . . . . 28

4.4.1 SIZE REDUCTION . . . . . . . . . . . 28

4.4.2 GRAPHITE BURNING . . . . . . . . . . . 31

4.4.3 BURNER OFF-GAS TREATMENT . . . . . . . . 37

4.4.4 ASH PACKAGING \& ACCOUNTABILITY . . . . . 39

4.4.5 RADIOACTIVE SOLIDS TRANSPORT AND HANDLING 41

4.5 PILOT PLANT TESTING OF EQUIPMENT AND PROCESS

SYSTEMS . . . . . . . . . . . . . . . . . . . . 44 4

4.6 SYSTEMS EVALUATIONS . . . . . . . . . . . . . 47

4.7 PROGRAM CONTROL . . . . . . . . . . . . . 48

4.8 PROCESSING FACILITIES . . . . . . . . . . . 49 
APPENDIX . . . . . . . . . . . . . . . . . 51

GRAPHITE SPENT FUELS CONDITIONING PROGRAM

WBS RESOURCE APPLICATION TABLES

FIGURES

1.1 Spent Graphite Fuel Treatment Block Diagram of

options . . . . • . . . . . . • . . . . . . . 2

1.2 Spent Graphite Fuel Conditioning . . . . . . . . 4

2.1 FSV Standard Fuel Element . . . . . . . . . . 7

2.2 Peach Bottom Unit 1 , Core 1 Fuel Element . . . 8

3.1 FSV Spent Fuel Disposal Research and

Development Schematic Presentation of options . . 13

4.1 Direct Fuel Disposal . . . . . . . . . . 16

4.2.1 Mechanical Fuel Disassembly . . . . . . . . . 20

4.2.2 Empty Block Disposal . . . . . . . . . . . . 23

4.2.3 Spent Fuel Rod Disposal . . . . . . . . . 26

4.3 Spent Fuel Inspection/Examination . . . . . . . 29

4.4.1 Fuel size Reduction . . . . . . . . . . . . 32

4.4.2 Graphite Burner \& Off-Gis Treatment . . . . . . . 36

4.4.4 Ash Packaging \& Solids Transport . . . . . . . . 42

4.5 Pilot Plant Modules . . . . . . . . . . 46

TABLES

2.1 Comparison of Fort st. Vrain and Peach Bottom

Fuels . . . . . . . . . . . . . . . . 9 


\section{ABSTRACT}

Irradiated (or spent) graphite fuel stored at the Idaho chemical Processing Plant (ICPP) includes Fort st. Vrain (FSV) reactor and Peach Bottom reactor spent fuels. Conditioning and disposal of spent graphite fuels presently includes three broad alternatives: 1) direct disposal with minimum fuel packaging or conditioning, 2) mechanical disassembly of spent fuel into high-level waste and low-level waste portions to minimize geologic repository requirements, and 3) waste volume reduction via burning of bulk graphite and other spent fuel chemical processing of the spent fuel. A multi-year program for the engineering development and demonstration of conditioning processes is described. Program costs, schedules, and facility requirements are estimated. 


\section{SUMMARY}

Irradiated (or spent) graphite fuel stored at the Idaho chemical Processing plant (ICPP) includes mainly fort st. Vrain (FSV) reactor and Peach Bottom reactor spent fuels, with much smaller quantities of unirradiated (PARKA and LANL fuels) Rover type fuel. The presently stored FSV fuel comprises three segments $(744$ blocks) from the reactor, with an additional six segments ( 1500 blocks) contractually planned for receipt and interim storage. All ICPP graphite fuels are in dry storage either in the Irradiated Fuel storage Facility (IFSF) or in underground silos.

Disposal of these graphite fuels has become a technical and political need. The Graphite Fuels conditioning program will evaluate alternatives for graphite fuel conditioning and dispositioning in a safe and efficient manner, while meeting the Environmental Protection Agency (EPA), Nuclear Regulatory Commission (NRC), and other environmental constraints or criteria. Upon selection of acceptable alternative conditioning means or processes, each will be developed through successive steps of laboratory process verification, component/subsystem sistem, full-scale or near-full-scale system testing, and integrated system testing prior to construction of a graphite fuels treatment facility. Conceptual design and cost estimate of the disposal facility will be developed.

Conditioning and dispositioning of spent graphite fuels presently includes three broad alternatives: 1) direct disposal with minimum fuel packaging or conditioning, mechanical disassembly of spent fuel into high-level waste and low-level waste portions to minimize geologic repository requirements, and 3 ) waste volume reduction via burning of bulk graphite and chemical processing of spent fuel.

A multi-year program for the engineering development and demonstration of conditioning processes has been developed. The program plan summarizes the justification for the overall program and describes the graphite fuel types to be considered. Each major alternative is described as well as the program steps required therein. A schedule of activities and identification of key milestones is provided. 


\section{OBJECTIVE}

The objective of this program is to establish disposal criteria, and to perform development, engineering, and demonstration of spent fuel conditioning methods for Fort St. Vrain (FSV) and other spent graphite fuels.

\section{$1.1 \quad$ Current Status}

Graphite fuels previously have not been thoroughly evaluated for direct disposal. An expert-opinion evaluation was recently documented by 0 ak Ridge National Laboratory (ORNL), and it strongly encouraged further evaluation of the direct geologic disposal option. Some evaluations and some development applicable to disposal have been completed regarding handling and disassembly of the fuel. Much more extensive development has been made on processing of FSV spent fuel for purposes of recycling the recoverable fissionable material, and some of the processing techniques may be applicable to fuel disposal.

\subsection{Establish Criteria}

This program will evaluate the waste-repository interaction, interpret regulatory requirements, and assess the impacts of the public review and licensing process as they relate to preliminary, established criteria for disposal technologies. Technical data resulting from the development programi will be input to DOE-RW, EM, and NE to assure adequate criteria are developed.

\subsection{Evaluate Candidate Technologies}

Present concepts for direct geologic disposal of graphite fuels include 1) direct packaging of graphite elements in a standard repository canister, and 2) other concepts involving some processing of the elements to decrease volume (e.g., remove excess carbon material) and to condition the remaining material for acceptable disposal. (See Figure 1.1) A thorough review of scientific and nuclear literature will be made to identify additional concepts for direct disposal. A feasibility study will be performed on each candidate process and will include: 1) comparison with established criteria and objectives, 2) preparation of conceptual flowsheets where possible, 3) evaluation of technical feasibility and risk, 4) analyses relative to reliability, operability, and environmental impact, and 5) comparative system cost of candidates. An overall comparative examination of the candidate processes will be made to select the best options for further development. 

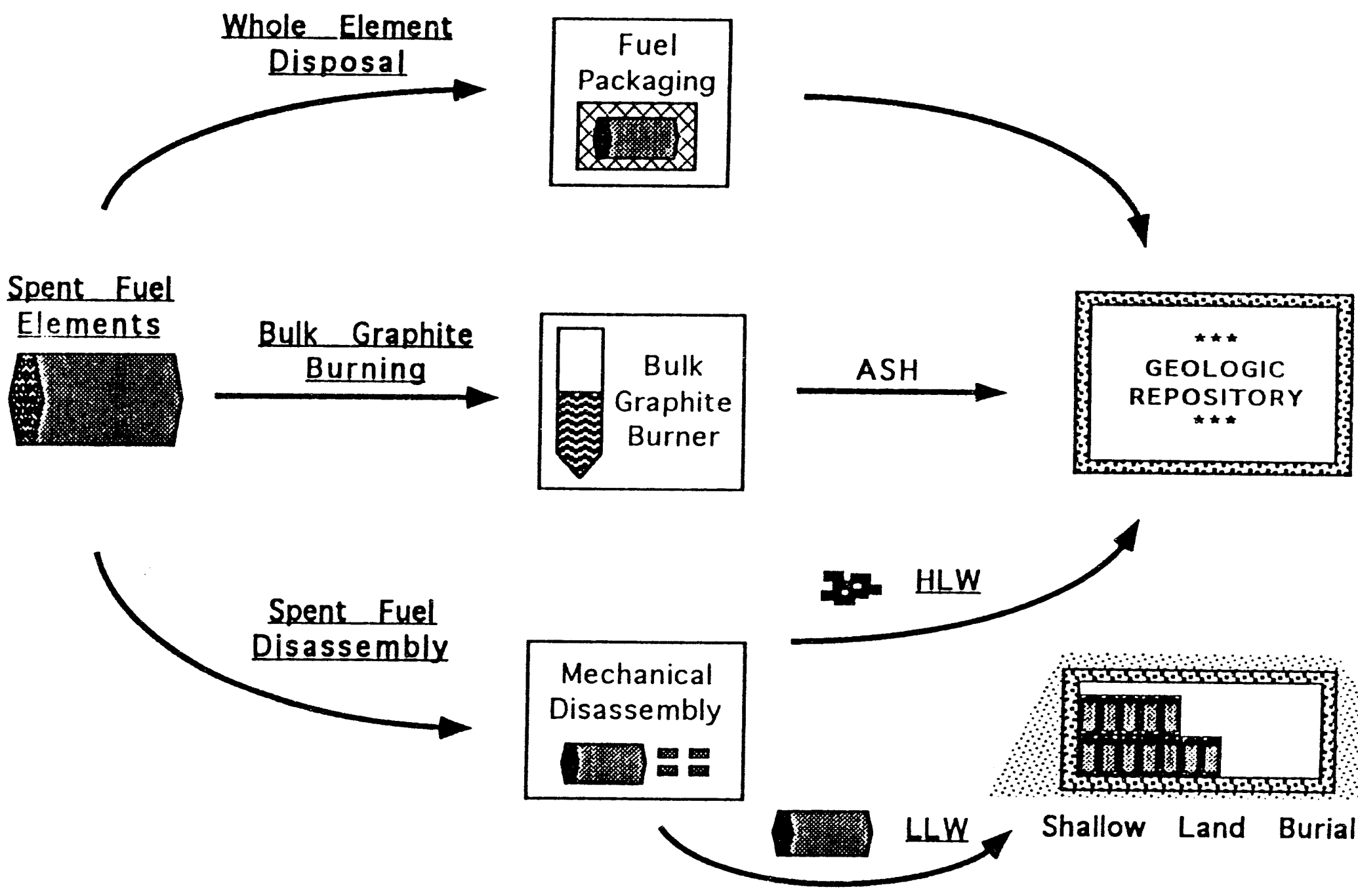

Figure 1.1 SPENT GRAPHITE FUEL TREATMENT BLOCK DIAGRAM OF OPTIONS 


\subsection{Laboratory Testing}

Laboratory testing will be performed on key portions of selected conditioning options to determine fundamental process and physical phenomena required for further process and equipment development. These tests will determine chemical reactivity and long-term stability within the process or repository environment, leachability rates, handling characteristics of fuel blocks, response to accident and abnormal conditions, heat transfer rates in proposed canisters, and repository canister corrosion rates.

\subsection{Component and Subsystem Testing}

Unirradiated and representative dummy fuel blocks and fuel rods (compacts) will be obtained for testing with remote mechanical handling equipment. Equipment will be assembled and tested for mechanical separation of fuel rods from the fuel block. Individual fuel components (e.g., FSV fuel rods) will be examined and tested. Loading tests of dummy fuel components into test canisters will be performed.

\subsection{Demonstration Testing}

Full or near-full-scale testing of the dispositioning equipment and processes will be conducted as a verification or proof of concept. Each process step and equipment item will be thoroughly tested to assure its ability to meet design criteria. Data will be obtained on operability, reliability, and maintainability. With completion of individual tests, integrated system and component tests will be performed.

\subsection{Schedule and Milestones}

An overall program and milestones schedule is depicted in Figure 1.2.

The program will follow sequentially, with alternatives identification and evaluation, laboratory and component testing, component sub-system support, pilot plant scale testing, and hot pilot plant testing of selected equipment. Preliminary geologic disposal criteria will be established early as a key guide to later engineering development and demonstration. (The disposal criteria will be upgraded and revised as needed.) A key milestone will be the selection of preferred spent fuel conditioning method by the end of FY 1994. The engineering schedule will be planned to prepare for a FY 2000 project for graphite fuels conditioning. 


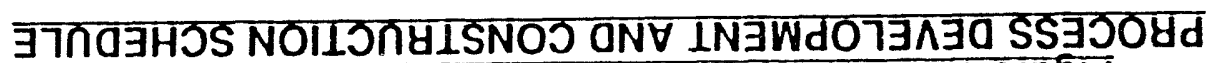

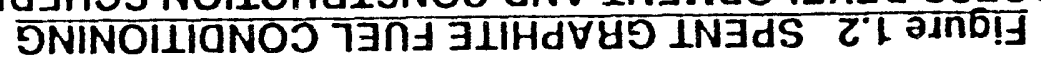

26/8-payวs рала0 ASt

$26 / 8 / 6 \cdot 873$

S $\forall \forall \wedge N I \exists W I$

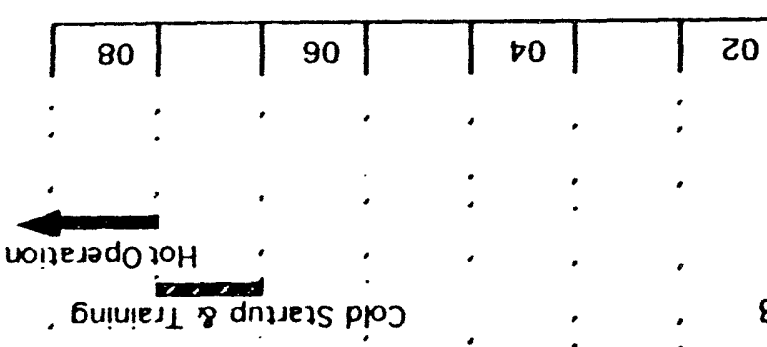

bululed 8 dnjeas ppo

. volpondzsuoj \& juaurañodd

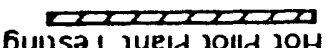

Guijsa 1 jueld jolld ppo

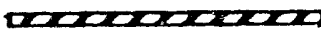
juauasnjosd dịbz 1521 dd Joddns waisKsqns juavoduros 6u!nsal fuavoduoj 8 qe? sassajoid dit jen\}

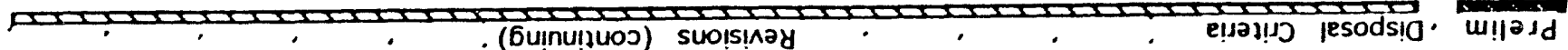

\section{6}

NOIIVINJWกDOO

NOIIYZ3dO $10 \mathrm{H}$

SNINIVY 8 dRIQYIS 070J

NOIIJTH ISNOJ

8 IN3WJanjoyd

N91530 3741

NIISZO THIIDJNOJ

तIIIJण IRIROIIONOJ

जाIII उIHdष्षु

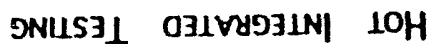

ONISIL O3LVOSINI OTOS

INJWJYOTOYd

INJWAINOZ INGI 107ld

INISISI

WJISASBIS/INANOAWOJ

SNISIL A8OLV8OQ77

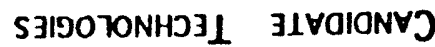

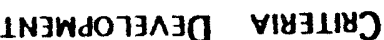

INIWगण

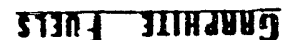




\subsection{References}

1. Allotts, et.al., Options for Treating High-Temperature Gas-Cooled Reactor Fuel for Repository Disposal, ORNL/TM-12027 (February 1992)

2. C. L. Bendixsen, et.al., Preliminary Development and Engineering Plan for Processing Fort St. Vrain Fuel, WIN-300 (January 1990)

3. Consolidated Fuel Reprocessing Program: Summary Deposit for the Period January 1, 1974 to November 30, 1983, GA-A17341 (November 1983) 


\section{COMPARISON OF GRAPHITE FUELS}

Spent graphite fuels at the Idaho Chemical Processing Plant (ICPP) are primarily High Temperature, Gas-Cooled Reactor (HTGR) and Peach Bottom fuels. Additional HTGR graphite fuels are stored at the Fort St. Vrain reactor in Colorado. A typical HTGR fuel element (or block) is shown in Figure 2.1. A typical Peach Bottom fuel element is shown in Figure 2.2. A third type of graphite fuel, PARKA, is also stored at ICPP but is unirradiated. The disposal of the unirradiated PARKA fuel is not a direct part of this program, but some of the process development here in may affect how this fuel is stored, processed, and managed.

Data on FSV and Peach Bottom fuels are detailed on Table 2.1. Data shown are for a "typical" fuel element. Differences batween fuel elements within a single reactor are to be expected (e.g., FSV core 1 had 3 fuel block designs and 84 different fuel block loadings).

At shutdown, The FSV reactor had produced 2,242 fuel blocks requiring storage and disposal. At this time, 744 blocks are stored in the Irradiated Fuel Storage Facility (IFSF) at the ICPP. The remaining irradiated blocks are stored in a facility owned and operated by the FSV reactor operator, Public Services of Colorado (PSC).

The Peach Bottom spent fuel at the ICPP consists of 1603 elements stored either in the IFSF or in ICPP dry wells underground. The ICPP spent fuel contains an estimated $332 \mathrm{~kg}$ uranium $(67.2 \% \mathrm{U}-235)$. Additional Peach Bottom fuel (364 $\mathrm{kg}$ uranium) are stored at Test Area North (TAN) on the Idaho National Engineering Laboratory (INEL), but the uranium enrichment is much lower $(<1.5 \%)$. 


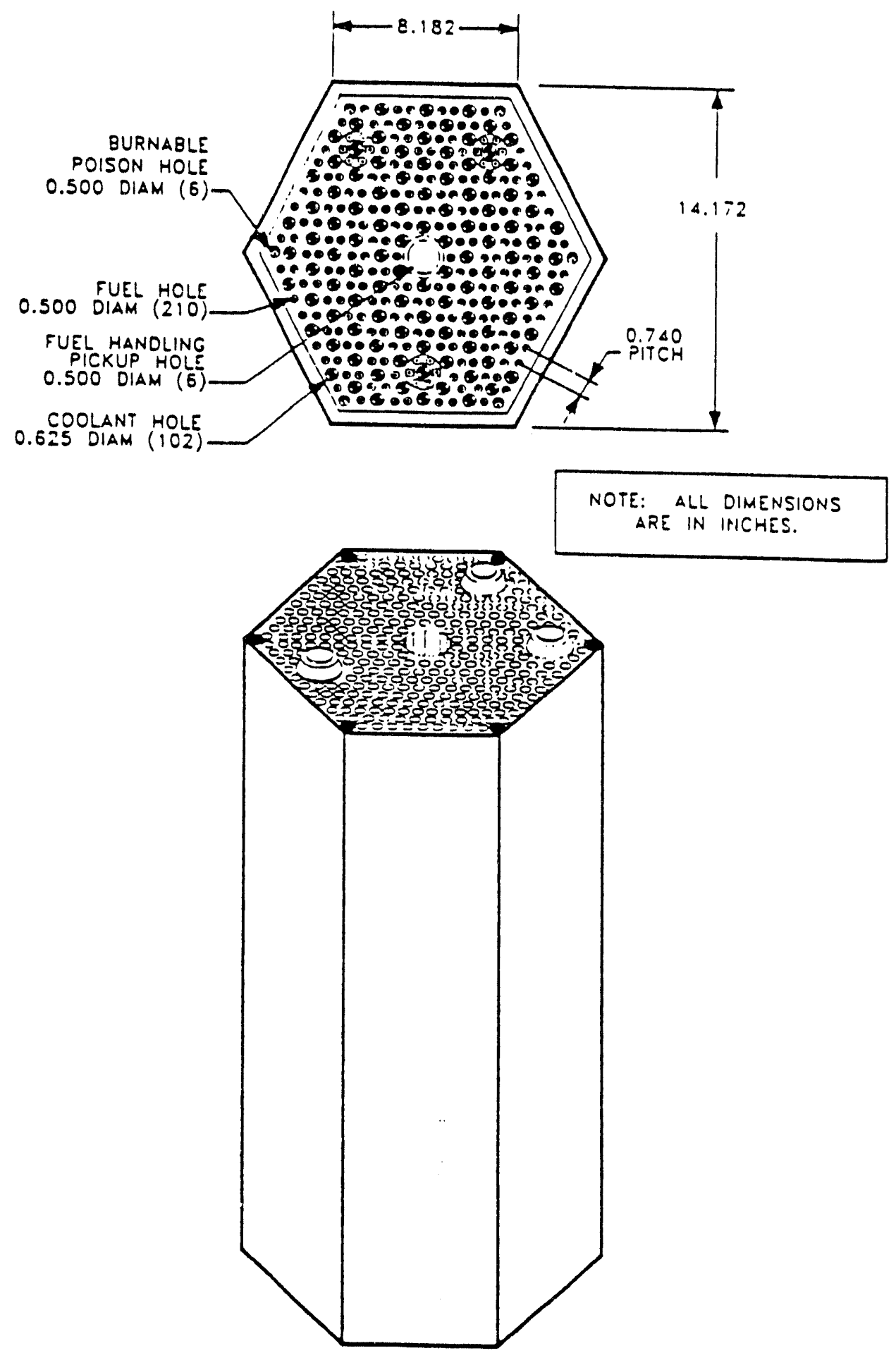

Figure 2-1 FSV STANDARD FUEL ELEMENT 


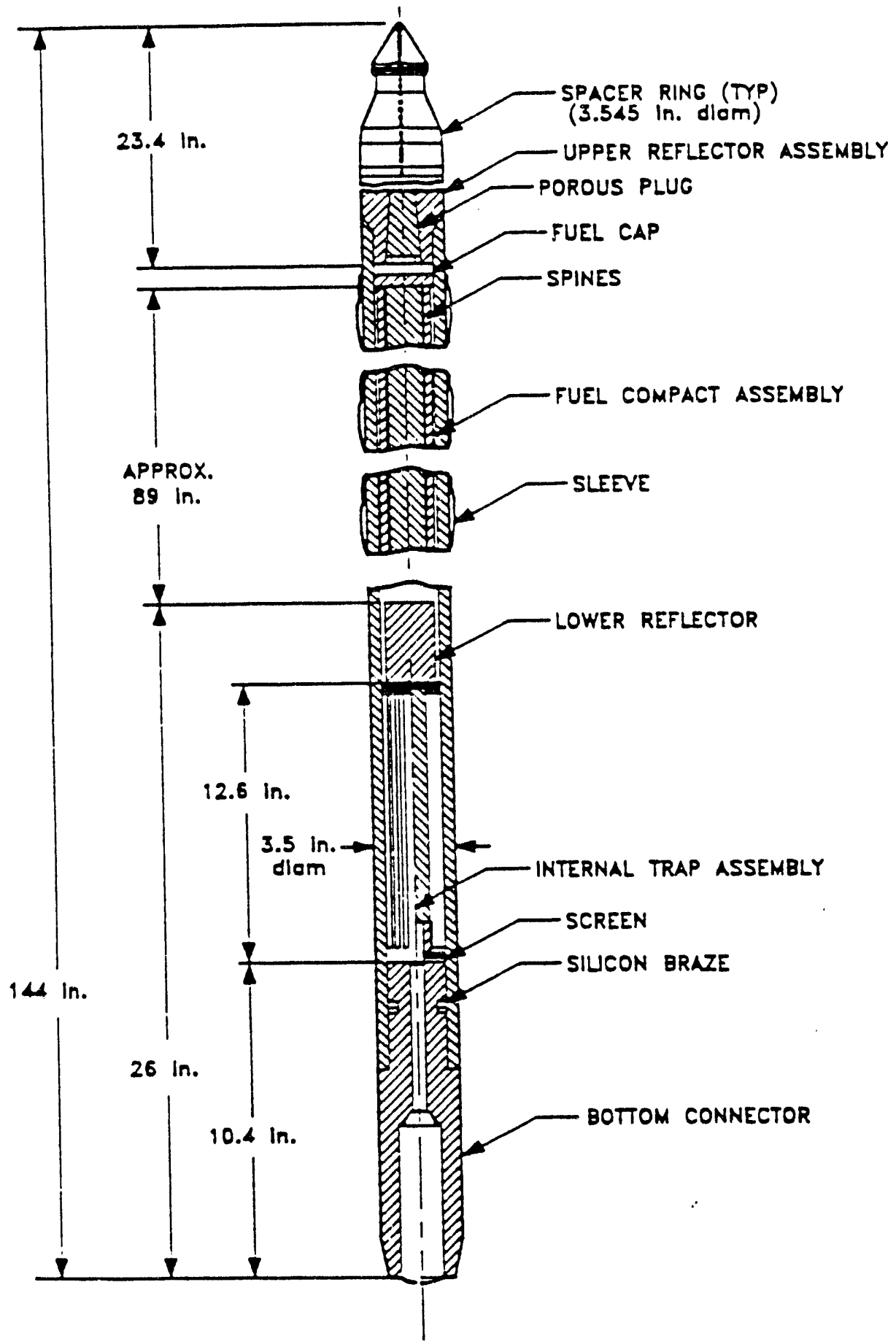

Figure 2-2 PEACH BOTTOM UNIT 1, CORE I FUEL ELEMENT 
Table 2.1

COMPARISON OF FORT ST. VRAIN AND PEACH BOTTOM FUELS

\section{CHRACTERISTIC}

Dimensions

Radius to Side $(\mathrm{mm})$

Radius to Vertex ( $\mathrm{mm}$ )

Height
ESV-HTGR

Fuel Channels

Number

Diameter $\quad(\mathrm{mm})$

Fueled Length $(\mathrm{mm})$

Coolant Channels

Number

Diameter

$(\mathrm{mm})$

Target/Poison Channels

Number

Diameter

Fuel

Diameter $\quad(\mathrm{mm})$

Length ( $\mathrm{mm}$ )

No. Rods/Fuel Element (FE)

Fuel Particles

Fissile

$$
\text { Type }
$$

Kernal Composition

Enrichment

(\% U-235)

Expected Bumup ( $\%$ FIMA)

Kermal Diameter ( $(\mu \mathrm{m})$

Buffer Thickness $(\mu \mathrm{m})$

IPyC Thickness ( $\mu \mathrm{m})$

SiC Thickness $(\mu \mathrm{m})$

OPyC Thickness $(\mu \mathrm{m})$

Total Diameter

$(\mu \mathrm{m})$

Fertile

Type

Kernal Composition

Kernal Diameter

Buffer Thickness

IPyC Thickness

SiC Thickness

OPyC Thickness

Total Diameter

$(\mu \mathrm{m})$

$(\mu \mathrm{m})$

$(\mu \mathrm{m})$

$(\mu \mathrm{m})$

$(\mu \mathrm{m})$

$(\mu \mathrm{m})$

Burnup, MWD/MTIHM
180

208

793

210

12.7

749

108

n a

n a

Rods

12.7

49

3132

Core 1 Core 2

TRISO

(U,Th) $\mathrm{C}_{2}$

93.1

22.4

225

50

20

20

40

485

$\mathrm{UC}_{2}$
93.1

93.1

120

$55 \pm 10$

44.5

n a

Bottom

.

Annulus

n a

n a

n a

230

BISO

$\mathrm{UC}_{2}$

93.1

-

120

$55 \pm 10$

$55 \pm 10$

n a

n a

340

\begin{tabular}{ccc} 
TRISO & \multicolumn{1}{c}{ BISO } \\
$\mathrm{ThC}_{2}$ & $\mathrm{ThC}_{2}$ & $\mathrm{ThC}_{2}$ \\
525 & 485 & 410 \\
50 & $55 \pm 10$ & $55 \pm 10$ \\
20 & $\mathrm{n} \mathrm{a}$ & $55 \pm 10$ \\
20 & $\mathrm{n} \mathrm{a}$ & $\mathrm{na}$ \\
50 & $\mathrm{n} \mathrm{a}$ & $\mathrm{na}$ \\
805 & 595 & 630 \\
$<50,000$ & 35,000 & 73.000
\end{tabular}


Table 2.1, cont'd

COMPARISON OF FORT ST. VRAIN AND PEACH BOTTOM FUELS

\section{CHRACTERISTIC}

$\begin{array}{ll}\begin{array}{c}\text { Component Masses (Fresh } \\ \text { Fuel Element Total }\end{array} & \begin{array}{l}\text { F } \\ \text { M g })\end{array} \\ \text { Matrix Carbon } & (\mathrm{kg} / \mathrm{FE}) \\ \text { Fuel Rod Carbon } & (\mathrm{kg} / \mathrm{FE}) \\ \begin{array}{l}\text { Coating Carbon } \\ \text { Silicon Carbide }\end{array} & (\mathrm{kg} / \mathrm{FE}) \\ & (\mathrm{kg} / \mathrm{FE}) \\ & \\ \text { Total Thorium } & (\mathrm{kg} / \mathrm{FE}) \\ \text { Total Uranium } & (\mathrm{kg} / \mathrm{FE}) \\ & \\ \text { Major Transuranics } & (\mathrm{at}) \text { Discharge) } \\ \text { Uranium-238 } & (\mathrm{g} / \mathrm{FE}) \\ \text { Uranium-235 } & (\mathrm{g} / \mathrm{FE}) \\ \text { Uranium-233 } & (\mathrm{g} / \mathrm{FE}) \\ \text { Uranium-236 } & (\mathrm{g} / \mathrm{FE}) \\ \text { Uranium-232 } & (\mathrm{ppm}) \\ \text { Thorium-232 } & (\mathrm{g} / \mathrm{FE}) \\ \text { Plutonium-238 } & (\mathrm{g} / \mathrm{FE}) \\ \text { Plutonium-239 } & (\mathrm{g} / \mathrm{FE}) \\ \text { Mixed Fission Products } & (\mathrm{g} / \mathrm{FE})\end{array}$

ESV-HTGR Peach Bottem

$\begin{array}{cc}128 & 41 \\ 86 & - \\ 4.08 & - \\ 20.04 & - \\ 4.1 & 0 \\ 13.154 & \sim 1.5 \\ 0.626 & \sim 300 \\ & \\ 32 & \\ 177 & -20 \\ 237 & 139 \\ 70 & 29 \\ 220 & -20 \\ 2720 & - \\ 0.9 & - \\ 0.7 & - \\ 870 & 0.5\end{array}$

Notes for Table 2.1:

1. Information concerning configuration and composition of fuels is composed of typical or average values selected to provide a representative design basis for processing technology development.

\section{SOURCES FOR INFORMATION IN TABLE 1-1}

1. Chracteristics of Spent Fuel High-Level Waste, and Other Radioactive Wastes Which May Require Long-Term Isolation DOE/RW-0184, Vol. 7 of 8 (June 1988)

2. Commercial MHTGR fuel element configuration and dimensions come from: "Seminar on MHTGR Technology," by Paul Kasten, January 17-19. 1989. Idaho Falls, ID.

3. FSVR fuel element composition comes from: "FSAR for For St. Vrain," Revision 6, July 22, 1988

4. FSVR transuranic and fission product information is for a six year irradiated, Segment 4 element at discharge as given in: GA-A-13886, HTGB Spene Fuel Composition and Euel Element Block Elow, Hamilton, C. J., et al., July $1,1976$.

5. R. N. Drake, Development and Engineering for the Graphile fuels Pilot Plant Facility (GFPP), Drake Engineering Incorporated, Helena, MT 59601 


\section{OPTIONS FOR CONDITIONING FUELS}

With the Department of Energy (DOE) decision to no longer reprocess spent fuel for fissile element recovery, identification and development efforts into alternative methods for spent fuel management, conditioning, and dispositioning are being expanded. A schematic of the fuel conditioning options for spent graphite fuels is shown on Figure 3.1.

As indicated earlier, options for waste management and disposal of spent graphite fuels comprise three primary areas:

- Direct Disposal -. disposal of spent graphite fuel elements (blocks or assemblies) directly into a geologic repository with minimal modification of the spent fuel or block element.

- Rod/Block Separation -- mechanical disassembly of fuel elements into:
a) low-level waste (LLW) comprised of bulk graphite pieces, and
b) high-level waste (HLW) comprised of fuel pieces container, the heavy metals (uranium, plutonium, etc.) and fission products

- Fuel Conditioning -- processing (graphite burning, off-gas cleanup, etc.,) of spent fuel assemblies and elements to reduce HLW volume requiring geologic disposal.

Based on early evaluations, direct disposal of "inert graphite" fuel elements into a geologic repository appears to be highly desirable. Thus, an early and primary effort will be made to identify the disposal criteria and evaluate the spent graphite fuel against that criteria. Direct disposal has the distinct advantage of apparent simplicity with an attendant reduction in handling and processing of radioactive spent fuel. As depicted in Figure 3.1 , direct disposal may require additional packaging to restrict movement of radioactive materials and heavy metals over the first 10,000 years storage. Necessary facilities will be evaluated for interim storage of spent fuel before the geologic repository is available.

Since storage space in a geologic repository is estimated to be very costly (estimates range from $\$ 400,000$ to $\$ 1,000,000$ per storage canister), there is considerable impetus to reduce the final volume of HLW which would be transferred to the repository. A volume reduction alternative would be disassembly of the spent fuel into HLW and LLW portions. For the FSV-HTGR this might be done through mechanical removal of the fuel rods (or compacts), containing the heavy metals and fission products, from the graphite fuel block (See Figure 3.1). The empty block would be further decontaminated (if necessary), encased as needed to encapsulate residual 
radioactive contamination (probably neutron activated isotopes such as carbon-14), and then transferred to a permanent site for shallow land burial. The HLW fuel rods (or compacts) would be encapsulated, stored for an interim period, and transferred to the geologic repository when available.

A third alternative would be chemical processing (or conditioning) of the spent fuel. This alternative (see Figure 3.1) would involve combustion of the spent fuel element (whole or crushed) to remove the bulk carbon, leaving a much smaller volume of spent fuel particles (burner ash) for encapsulation, interim storage, and transfer. In this alternative the burner off-gas would be filtered, washed, and otherwise treated to maintain environmental contamination below regulatory limits. The processing technology relative to this alternative is the best known of the three disposal alternatives. However, some technical questions remain, and demonstration of an integrated process for the FSV and the Peach Bottom spent fuels has yet to be completed. 


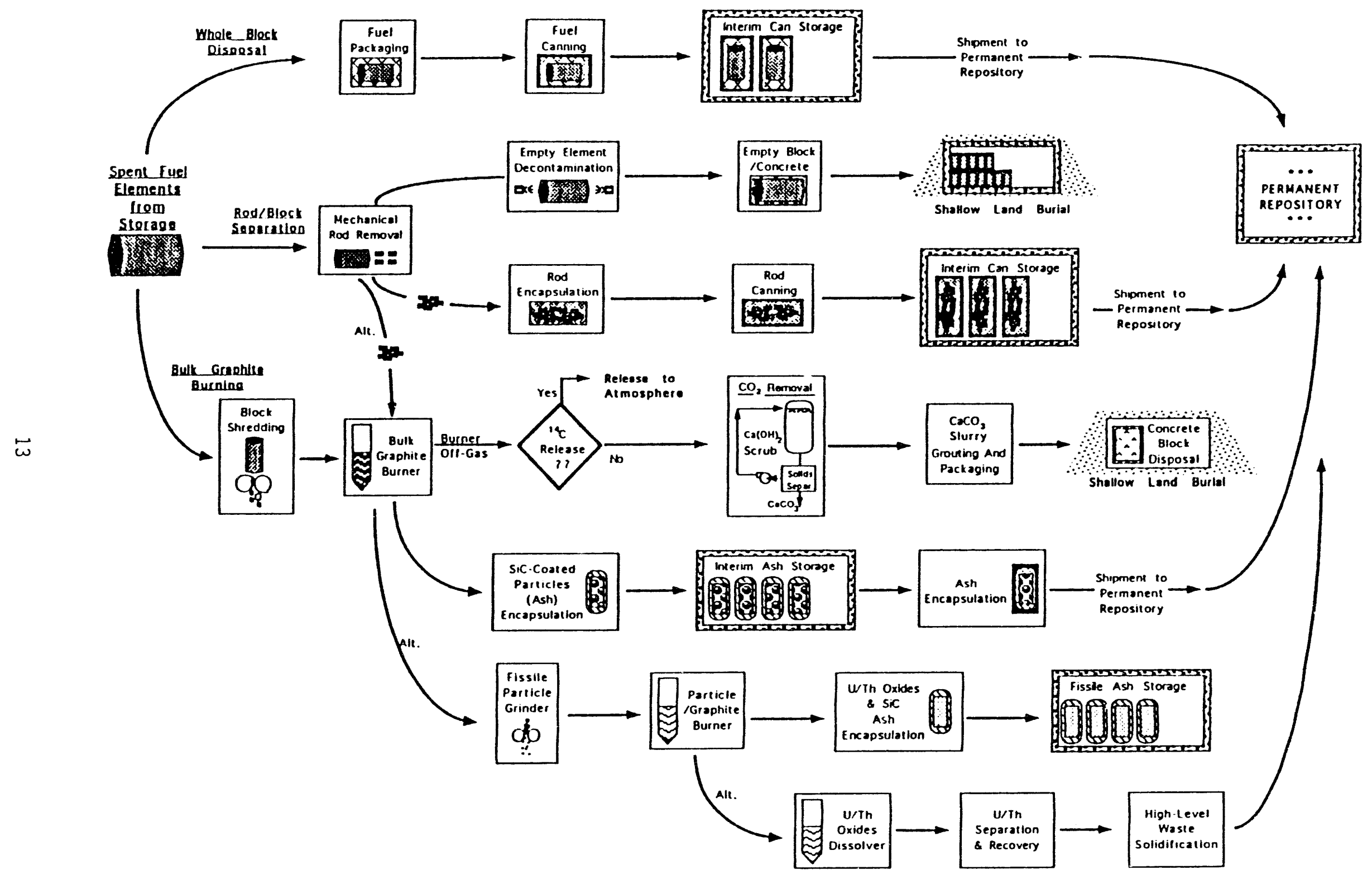

Figure 3.1 FSV SPENT FUEL DISPOSAL RESEARCH \& DEVELOPMENT SCHEMATIC PRESENTATION OF OPTIONS 


\section{DEVELOPMENT AND ENGINEERING PROGRAM}

Completion of engineering development and demonstration of spent graphite fuel conditioning will be a multi-faceted task requiring several years. Each of the major tasks is described in the section following. For each task, the objectives and functional description will be summarized, followed by sub-sections on prior development, existing technical needs and risks, development of testing facilities to be needed, and the development schedule. For each task, the funding and resource requirements have been estimated and are contained in the Appendix.

\subsection{DIRECT FUEL DISPOSAL}

(M. D. Staiger, D. L. Lord)

\subsubsection{Objective}

The disposal of spent graphite fuel as an unconditioned placement of the fuel directly either in the repository or in a handling and transportation barrier and contamination containment package is to be developed, including: evaluation of alternatives, development of spent fuel repository package, and demonstration of fuel handling needs.

Development Priority: High

\subsubsection{Functional Description}

Graphite fuels will be "embalmed" and packaged prior to disposal in the repository. This conditioning will be performed to assure that all fuels will meet repository criteria for long-term geologic disposal. Modeling activities need to be completed which quantify geologic repository confinement of spent fuel radioactive and hazardous species inventories. Evaluations need to be performed which identify fuel handling criteria. Fuel handling, transportation, and emplacement requirements need to be established which assure the safe handling of spent graphite fuels. The response of spent fuel to the repository environment needs to be demonstrated.

\subsubsection{Prior Development}

Direct disposal of graphite based fuel has been studied but no tests leading to demonstration have been performed. Limited evaluation by Oak Ridge National Laboratory (ORNL) of the Fort St. Vrain fuel direct disposal has been done but no development activities have been initiated for Fort St. Vrain or other graphite based fuels. Germany has evaluated and approved disposal of their specific graphite fuel types for storage in a salt dome repository. 


\subsubsection{Technical Needs Summary}

The primary requirement for the direct disposal is the establishment of criteria for the disposal package. Waste acceptance criteria for presently planned geologic repositories have not considered disposal of graphite based fuels. Therefore, the current disposal criteria must be examined carefully to understand their implications to graphite fuels. A primary companion need is an engineering scale demonstration of a suitabile waste form and its package for geologic disposal.

\subsubsection{Major Development Risks}

The major development risk is that the disposal criteria will not be accurately defined for graphite based spent fuels. If the criteria art inadequate, the fuel conditioning development activity may only partially meet geologic fuel disposal needs. Additional development then would have to be done which would adversely delay startup of the spent fuel disposal activities.

\subsubsection{Recommended Development Facilities}

Fuel Element and Scrap Pretreatment - Once a dispositioning technique is selected from laboratory tests, a pilot plant facility incorporating all operations will need to be built to demonstrate the concept operational aspects and to provide criteria for design and operation of a full scale facility.

Conditioned Fuel Canning - A pilot plant facility will be needed to demonstrate unproven technologies being used to package conditioned fuel.

Fuel Handling Mock-up - Special handling and interchangability requirements will need to be demonstrated for the different graphite fuel types.

\subsubsection{Development Schedule}

During FY 1993, the first tasks will be identification and evaluation of al ternative methods and concerns for direct disposal of spent graphite fuels (see Fig. 4.1). Since some effort has been previously performed, it is expected that early progress towards laboratory tests supporting selected methods may begin by mid-year. Evaluation and lab testing should be sufficiently complete by mid-Fy 1994 that a preferred direct disposal alternative may be selected for comparison with other alternatives for spent graphite fuel conditioning and disposal. Should direct disposal be the final disposal alternative, further laboratory testing and pilot plant testing will follow as indicated in Figure 4.1. The funding and resource requirements for this estimated in the Appendix, WBS \#3.0.

\subsubsection{Integration with Other Tasks}

This task will interface with both fuel inspection and systems evaluation tasks (Sections 4.3 and 4.6, respectively). Direct disposal may be successfully demonstrated and approved only with a thorough characterization of the spent graphite fuel types, accomplished after hot cell inspection and examination. A systems analyses of the direct disposal alternative(s) will be performed to assist in selection of optimum alternative. 


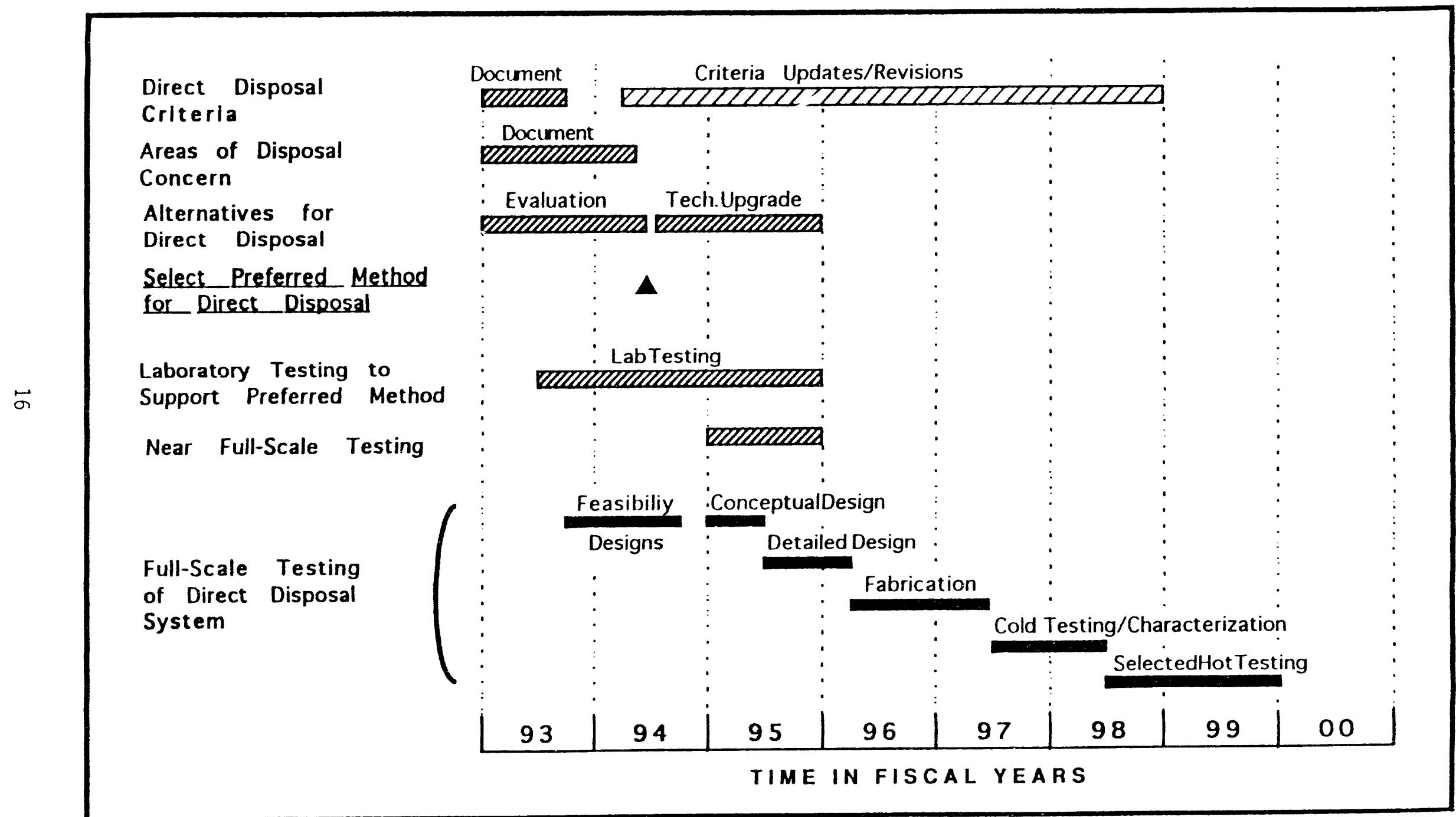

Figure 4.1 DIRECT FUEL DISPOSAL

CLB- $9 / 22 / 92$ DEVELOPMENT \& ENGINEERING SCHEDULE -- SPENT GRAPHITE FUEL CONDITIONING 


\subsubsection{References}

1. Characteristics of Spent Fuel, High-Level Waste, and Other Radioactive Waste Which May Require Long-Term I solation, DOE/RW0184, Vol. 7 of 8 (June 1988)

2. A. L. Lotts, et al., Options for Treating High-Temperature GasCooled Reactor Fuel for Repository Disposal, ORNL/TM-12027 (February 1992)

\subsection{MECHANICAL DISASSEMBLY}

Mechanical disassembly of spent graphite fuels has a significant potential for reducing the quantity and volume of high-level waste to be sent to a geologic repository. The program effort will be in three parts: fuel element disassembly (rod and block separation), empty block disposal, and rod disposal.

\subsubsection{FUEL ELEMENT DISASSEMBLY}

(D. L. Lord)

\subsubsection{Objective}

Demonstrate reliable FSV fuel element (FE) disassembly and rod removal at production rates of not less than three fuel elements per day.

Development Priority: High

\subsubsection{Functional Description}

Fuel elements will be transferred to a rod removal station and secured in place. Top and bottom end caps of fuel channels will be drilled (punched) out. Fuel rods will be punched out. Stuck fuel rods will be detected. Align blocked channel(s) with oversize core drill and drill out stuck fuel rods. Dust contamination will be controlled and collected. The final step will be to collect, inventory, and store the fuel rods.

\subsubsection{Prior Development}

Previous HTGR development programs have focused on whole element crushing and burning. Consequently, very little previous development data is available to support this disassembly task. A limited number of rods has been successfully removed from irradiated FSV fuel elements in hot cell facilities at GA Technologies. Following end cap removal and bottom drilling, rods were removed from one fuel channel at a time using a small pneumatic ram. The operation was labor intensive and slow, requiring up to an hour per fuel channel. Fuel rod removal was performed to supply a small number of irradiated fuel rods for testing in the Federal Repubiic of Germany (FRG) under the US/FRG Umbrella 
Agreement for Gas Cooled Reactor Development. Consequently, operational parameters helpful in assessing the feasibility of large scale and high-throughput rod removal were not obtained. Removal of fuel rods for post-irradiation examination of FSVR fuels was accomplished using a 6 -hole coring jig, which was positioned and aligned using the coolant channels.

\subsubsection{Technical Needs Summary}

Development activities for this task should address the following technical issues:

1) Determine the range of ram forces required to push fuel rods from properly prepared irradiated fuel elements.

2) Establish criteria for designating and detecting stuck rods to prevent excessive particle breakage, clamp failure, element failure, or collateral equipment damage from excessive ram forces.

3) Obtain sufficient data to allow probability prediction of encountering stuck rods as a function of fuel element design and irradiation history.

4) Obtain data to allow correlation of ram force and velocity with fuel particle breakage, fuel rod breakage, fuel element residual contamination, and fuel element failure.

5) Develop, design, and test a "ganged" element drilling and ram system to provide simultaneous and rapid rod removal from several fuel channels.

6) Obtain sufficient physical and mechanical property data to permit design of appropriate transfer, handling, and drilling equipment for irradiated fuel elements.

\subsubsection{Major Development Risks}

Element disassembly and rod removal are key steps in the overall processing flowsheet for all considered fuels. These steps must be accomplished reliably and successfully for all fuel types, configurations, compositions, and irradiation histories. The initial FSVR core loading contained 3 major types of fuel elements. If element disassembly and rod removal characteristics differ significantly and unpredictably as a function of element type and history, a significant risk will exist that the technical issues might not be resolved without excessive hot testing. In the worst case, development efforts may show that rod removal is not a feasible unit operation for processing of all fuel types. Therefore, bulk graphite burning (impacting burner and burner off-gas system design) will be mandatory. The penalty for this option may be that all oxides of carbon in the burner off-gas must be removed and converted to solid waste in order to prevent release of excessive carbon-14. Major costs would result. 


\subsubsection{Recommended Development Facilities}

Both cold and hot engineering scale pilot plant facilities will be required to accomplish this development task. Cold facilities may be used to develop designs and to test the mechanical components for element transfer, disassembly, and rod removal. Hot cell facilities will be required to demonstrate operations and to gather quantitative parametric data for behavior of irradiated fuel elements.

\subsubsection{Development Schedule}

Although some concepts for disassembly equipment have been made, a literature search and evaluation will be made early in FY-1993. Included in the search will be the identification of commercial manufacturers of desired mechanical equipment. Identification of a candidate or prototypical device will be made by March 1993, followed by procurement activities to be completed by September 1993. Testing of the prototype will follow immediately with the device having been installed either at ICPP or at remote mechanical test facilities at TRA.

With successful operation of the prototype, design and procurement of an improved version will follow as per the schedule shown in Figure 4.2.1. The funding and resource requirements for this task are estimated in the Appendix, WBS \#4.1 and 4.2.

\subsubsection{Integration with Other Tasks}

Fuel disassembly and rod removal are the first operations in the headend processing flow sheet. Failure to demonstrate the feasibility of these operations will have major impacts on virtually all subsequent unit operations. This development task should have a high priority and should be started early. Feasibility of rod removal must be established prior to prototype burner design and procurement.

\subsubsection{References}

1. Spent Fuel Processing in Support of the New Production Reactor, RHORE-EV-47, Section 5, Rockwell International, Hanford Operations, August 1984.

2. J. J. Saurwein, et al., Postirradiation Examination and Evaluation of Fort St. Vrain Fuel Element 1-0743, GA-A-16258, General Atomics Company, May 1981.

\subsubsection{BLOCK DISPOSAL}

(D. L. Lord)

\subsubsection{Objective}

Demonstrate techniques and equipment required for decontamination, monitoring, packaging, and loadout of empty fuel elements (blocks) in preparation for disposal.

Development Priority: High 


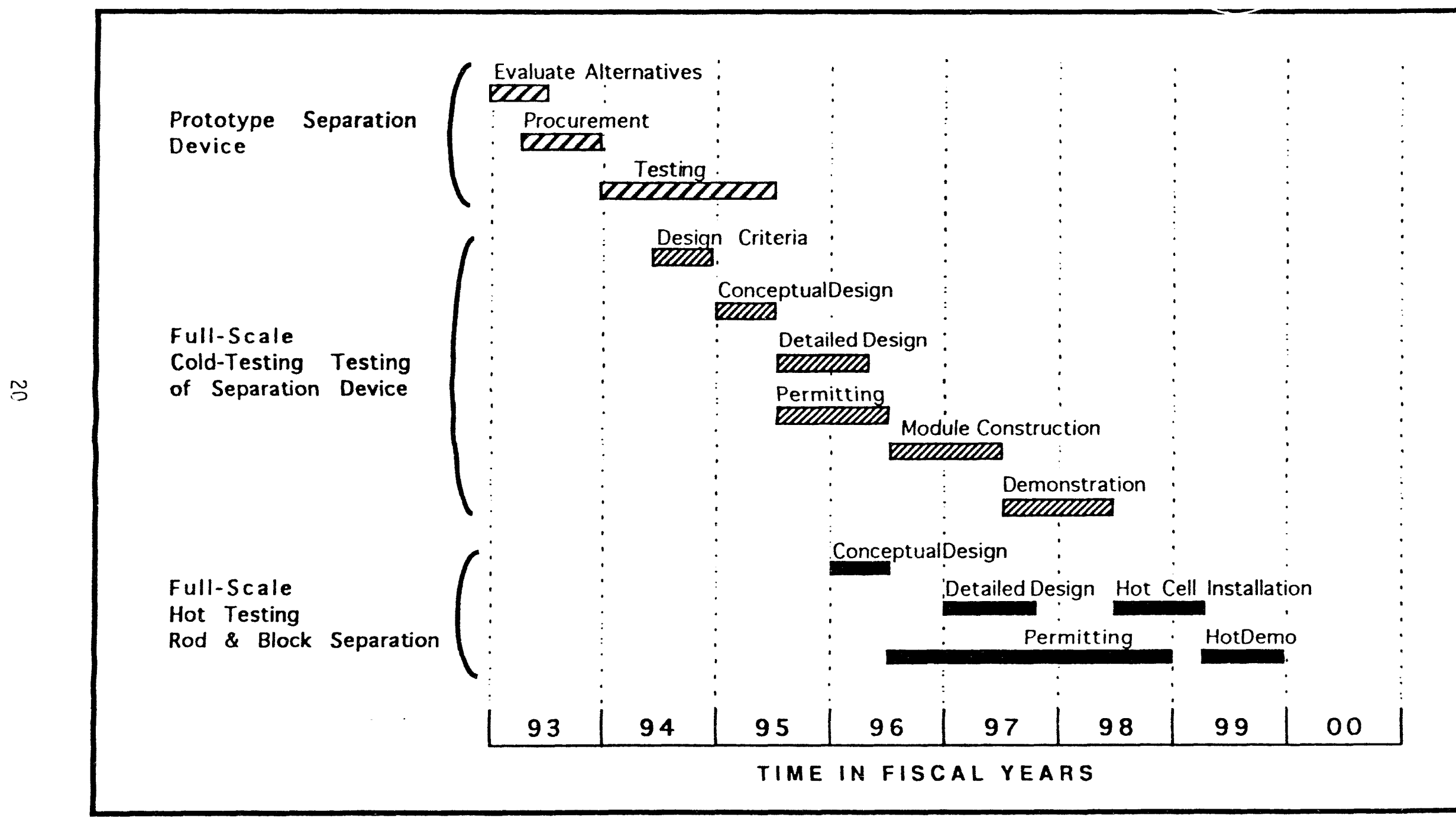

Figure 4.2.1 MECHANICAL FUEL DISASSEMBLY

CLB- $9 / 22 / 92$ DEVELOPMENT \& ENGINEERING SCHEDULE - SPENT GRAPHITE FUEL CONDITIONING 


\subsubsection{Functional Description}

Structural defects in empty fuel elements (EFE) will be sought and detected. Heavy metal and fission product contamination of EFEs will be located and quantified. The EFE will be decontaminated, with decontamination wastes treated and disposed. The clean EFE will be packaged for interim storage or transfer to long-term repository.

\subsubsection{Prior Development}

Previous HTGR processing flowsheets were based on burning all graphite from fuel element components. As a result, virtually no development has been done to support disposal of EFE. Although some measurements have been made which indicate that EFE satisfy regulatory criteria for lowlevel solid waste (LSW), the data is insufficient to support the corresponding EFE or LSW disposal flowsheets.

\subsubsection{Technical Needs Summary}

Development activities for this task should address the following technical issues:

1) Develop criteria for EFE disposal based on dimensional tolerances, presence of defects, and residual heavy metal and fission product contamination.

2) Develop hot cell analytical and measurement equipment necessary to determine if EFE satisfies disposal criteria.

3) Develop hot cell equipment to decontaminate EFE and to treat and dispose of decontamination wastes.

4) Develop equipment for packaging and loadout of decontaminated EFE.

Development and verification of decontamination and monitoring techniques will require both laboratory and engineering scale investigations, utilizing both irradiated and unirradiated materials. Hot prototype demonstration of decontamination and monitoring operations likely will be required prior to processing facility design.

\subsubsection{Major Development Risks}

If extensive decontamination is required for a large fraciion of the EFE, it is likely that the potential benefits of empty element disposal would be lost. Decontamination will probably require a mechanical procedure such as wire brushing, reaming, or frit blasting, with resulting dusts transferred to a rod or particle burner for disposal. The decision to decontaminate and dispose of EFE as a low level waste will depend on a 
comparative study of EFE decontamination and disposal costs versus increased costs for other systems and equipment. These include a larger rod burner, burner off-gas treatment, and carbonate grout disposal systems, which would be required to dispose of the additional graphite by burning.

\subsubsection{Recommended Development Facilities}

Cold pilot plant and hot cell facilities will be required to complete this development task. Engineering scale mechanical decontamination equipment will be developed in the cold pilot plant prior to hot demonstration. EFE measurement techniques and equipment may be developed in the cold pilot plant, but element monitoring techniques must be verified using irradiated material.

\subsubsection{Development Schedule}

Alternative methods for EFE disposal will be identified and evaluated during FY-1993 (see Figure 4.2.2). Some laboratory testing related to a preferred alternative will begin after mid-FY-1993. It is expected that sufficient technical data will be available during FY-1994, and that conceptual design may begin on a preferred method for demonstration disposal. The funding and resource requirements for this task are estimated in the Appendix WBS \#4.3.

\subsubsection{Integration with Other Tasks}

This development task is closely linked to the Fuel Element Disassembly and Rod Removal tasks (Sections 4.2 .1 and 4.2 .3 , respectively) in both technology and priority. Failure to demonstrate adequate decontamination of EFEs will require major flowsheet changes and will adversely affect the economics of fuel processing. This task should be given a high priority and should be started early. Feasibility of element decontamination must be established prior to burner and burner off-gas treatment system designs.

\subsubsection{References}

1. T. Dunn, J. Cordito, J. Cunliffe, Perspectives of Modular High Temperature Gas-Cooled Reactor on Effluent Management and Siting, GA-A-19702, GA Technologies Inc., San Diego, CA, July 1989. 


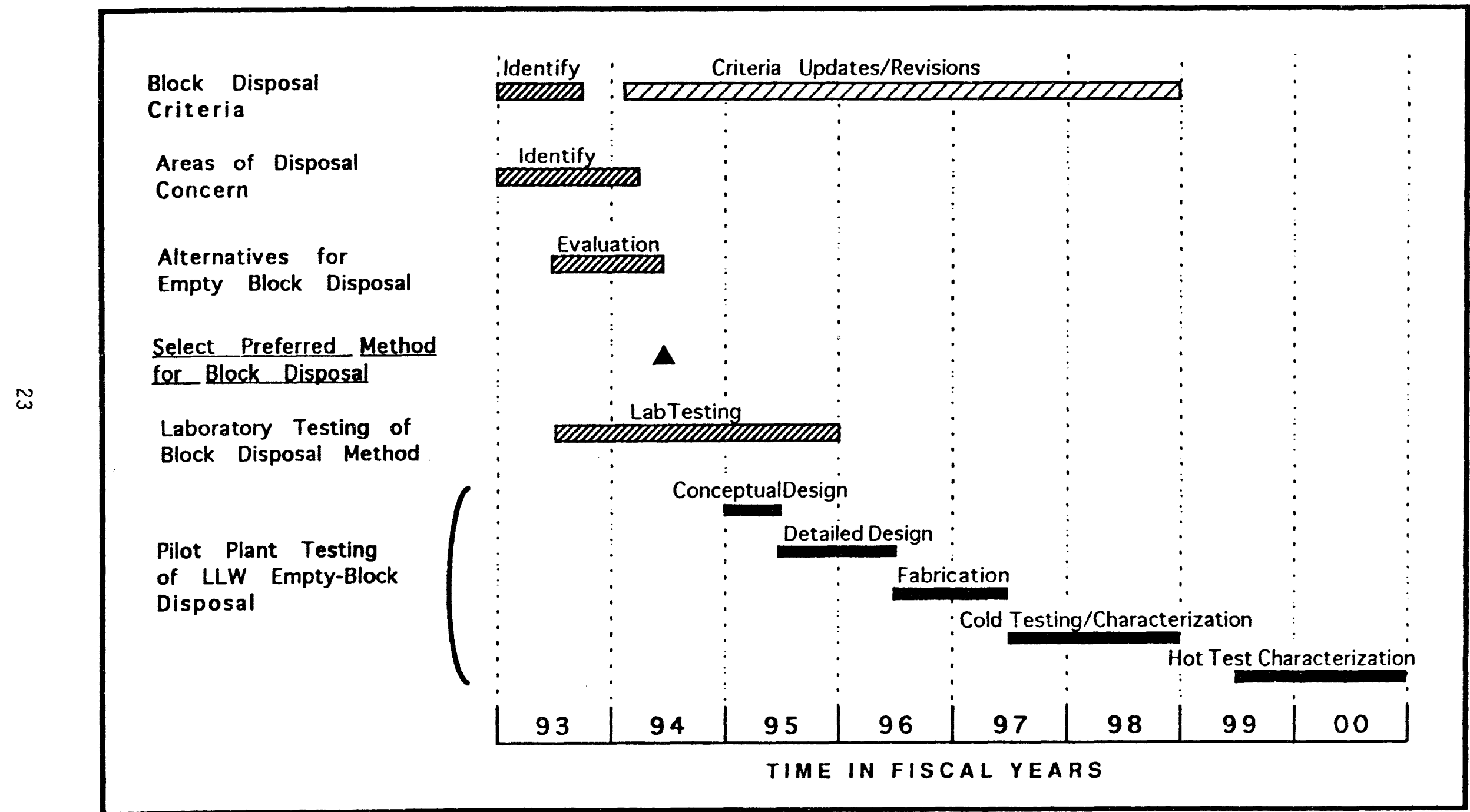

Figure 4.2.2 EMPTY BLOCK DISPOSAL DEVELOPMENT \& ENGINEERING SCHEDULE -- SPENT GRAPHITE FUEL CONDITIONING 


\subsubsection{ROD DISPOSAL}

\subsubsection{Objective}

(D. L. Lord)

Develop design data, techniques, and equipment for direct fuel rod disposal for FSVR, Peach Bottom, and PARKA.

Development Priority: High

\subsubsection{Functional Description}

The separated fuel rods are to be stored in a critically safe container. As with direct disposal of spent fuel, the separated rods are to be conditioned or packaged as per repository criteria. Fissile material will be fully accounted and characterized. Finally, the fuel canister will be shipped from interim storage to permanent repository.

\subsubsection{Prior Development}

Handling and transfer of fuel rods has not been addressed previously. Research and development work will be required.

\subsubsection{Technical Needs Summary}

Development activities for this task should address the following technical issues:

1) Determine encapsulation and canning requirements ensuring criticality safety.

2) Determine interim storage requirements.

3) Determine shipping and permanent repository requirements.

4) Evaluate change from "waste" to "resource" designation of fuel rods for possible future extraction from permanent repository.

\subsubsection{Major Development Risks}

This development task involves adaptation, improvement, and optimization of demonstrated technology. With one exception, no major development risks are associated with this task. The major concern will be the relative increase in criticality risk form whole blocks to separated rods.

\subsubsection{Recommended Development Facilities}

Cold engineering scale component development will be required to accomplish this task. No irradiated materials testing is anticipated.

\subsubsection{Development Schedule}

It is expected that the schedule herein will proceed similarly to that described in Section 4.2.2.7 (see Figure 4.2.3). The funding and resource requirements for this task are estimated in the Appendix, WBS \#4.4. 


\subsubsection{Integration with Other Tasks}

This is a low risk development task with only minor flowsheet and process feasibility impacts. However, this task must be coordinated with other component development work for element disassembly and rod removal, fuel rod and particle crushing, fuel burning, ash handling, and radioactive solids transport and handiing.

\subsubsection{References}

None to date. 


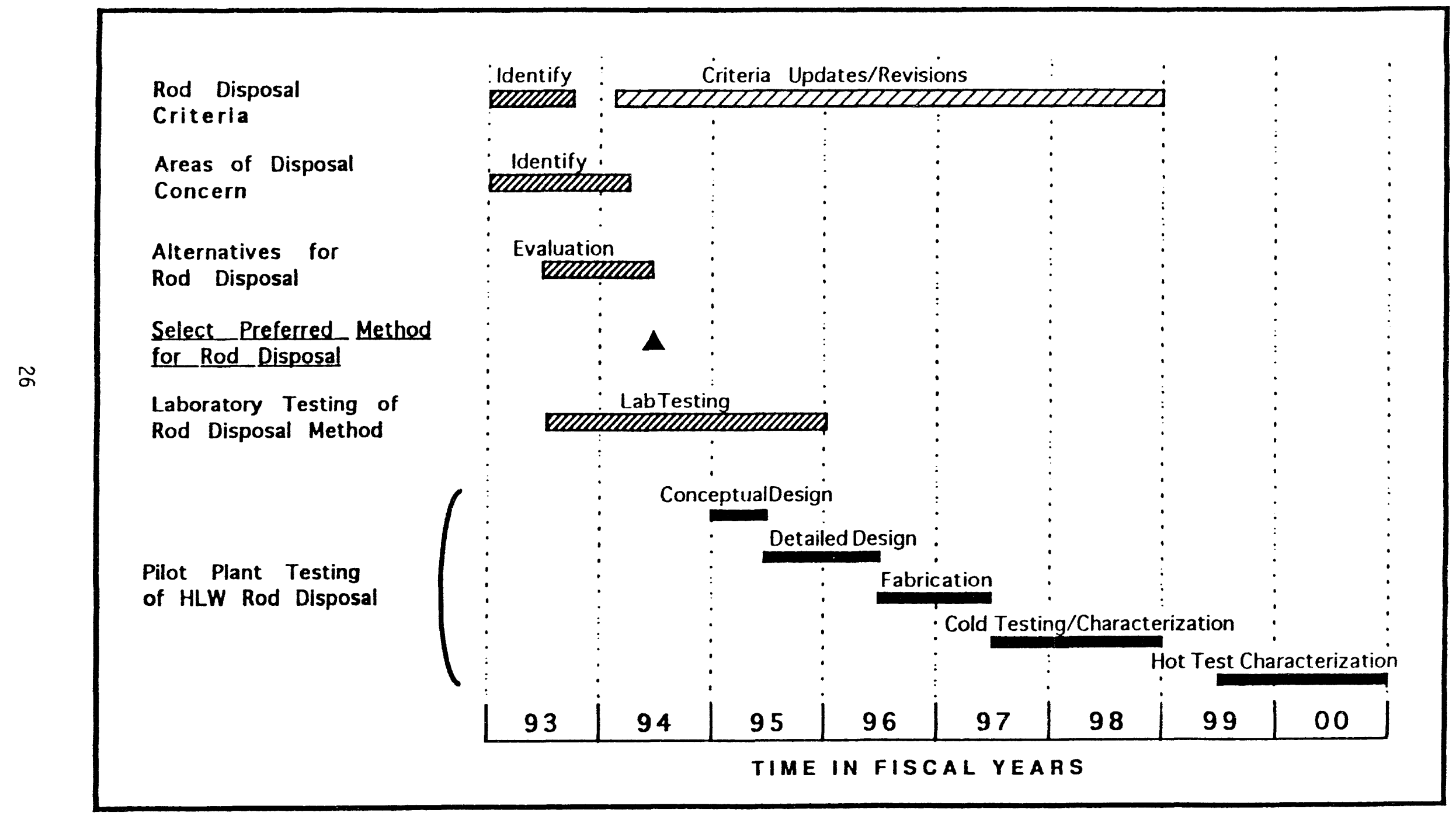

Figure 4.2.3 SPENT FUEL ROD DISPOSAL CLB-9/22/92 DEVELOPMENT \& ENGINEERING SCHEDULE - SPENT GRAPHITE FUEL CONDITIONING 


\subsection{FUEL EXAMINATION}

(C. L. Bendixsen)

\subsubsection{Objective}

Perform examination of spent graphite fuels and determine fuel characteristics, e.g., fuel dimensions, structural performance, chemical forms, fission product distributions, etc.

Development Priority: High

\subsubsection{Functional Description}

Fuel characterization requirements are to be documented. The quantity and number of spent fuel elements to be examined is to be defined. Identify and upgrade/modify the fuel examination facilities as needed. Facility permitting requirements will be completed. Required spent fuel for the examination will be packaged and transferred to the appropriate facility. The fuel will be examined both destructively and nondestructively, and the characterization results documented.

\subsubsection{Prior Development}

Storage data has been assembled on spent graphite fuels at ICPP. Additional data from appropriate reactor operations is being sought. The General Atomics Corp. has examined and documented one spent flel graphite fuel block from the FSVR.

\subsubsection{Technical Needs Summary}

Preliminary evaluation has ident ified the Test Area North (TAN) hot shops (presently operated by EG\&G) as a desirable fuel examination facility. However, the TAN hot shops will require some modification and upgrade, plus some new equipment for handling the spent graphite fuels. A new safety analysis evaluation and report will need to be prepared. Other safety and environmental permitting must also be obtained. An a)ternate facility to the TAN hot shops may be at the EBR-II site Hot Fuel Examination Facility (HFEF). Hot cells located at the Test Reactor Area (TRA) also will be used to examine pieces some fuel.

\subsubsection{Major Development Risks}

The EG\&G presently has funding to prepare a detailed proposal for FSR spent graphite fuel examination. This examination would be in support of DOE-NE MHTGR commercialization efforts. Per direction from DOE-ID, WINCO is to input specific needs for fuel conditioning and repository characterization into the EG\&G proposal. A significant risk to this program is potential that the EG\&G proposed program would neither be funded adequately nor meet the schedule needed by this program. Should this lack of funding occur, additional funding would be needed within this program and would need to be identified. 


\subsubsection{Recommended Development Facilities}

It is assumed that the TAN hot shops may be upgraded and modified for the examination of spent graphite fuels.

\subsubsection{Development Schedule}

The schedule (see Figure 4.3) for this task is in very early stages as the EG\&G examinations proposal is in very early stages. The program proposal is to be completed during FY 1993. Two to three years of facility preparation followed by at two year fuel examination period are anticipated. Funding and rescurce requirements for this task are in the Appendix, WBS \#6.0. However, the WBS is only for WINCO support to the EG\&G proposal. The EG\&G proposed costs are expected to be much higher.

\subsubsection{Integration with Other Tasks}

The spent fuel characterization is an important precursor to detailed design of spent fuel conditioning process, equipment, and facility. Equipment and process needs can on y be considered as assumptions until fuel examination has accurately defined spent fuel characteristics. Data from fuel examinations could be useful as early as FY 1995, but will be required by FY 1997.

\subsubsection{References}

None

\subsection{FUEL PROCESSING}

Processing of spent graphite fuels may prove a desirable alternative because of the potential for significant reductions in HLW being sent to a geologic repository. Major processing alternatives are described in the following sections: fuel size reduction (block crushing or shredding), bulk graphite burning, burner off-gas treatmient, burner ash accountability, and solids transport and handling.

\subsubsection{SIZE REDUCTION}

(M. B. Phillips)

\subsubsection{Objectives}

Develop and demonstrate remote techniques, materials, and equipment to accomplish fuel size reduction (block shredding), handling, and storage. 
Decument Examination

Requirements

Update and Identify

Special Examination

Requirements

Detailed Examination

Prearam Plan

Preparation of

Examination Facilities

Prepare Fuel Handling

Tools \& Equipment

NEPA \& State Permitting

Obtain Req'd Fuel

Assemblies

FSVR-HTGR and

Peach Bottom

Fuel Examination

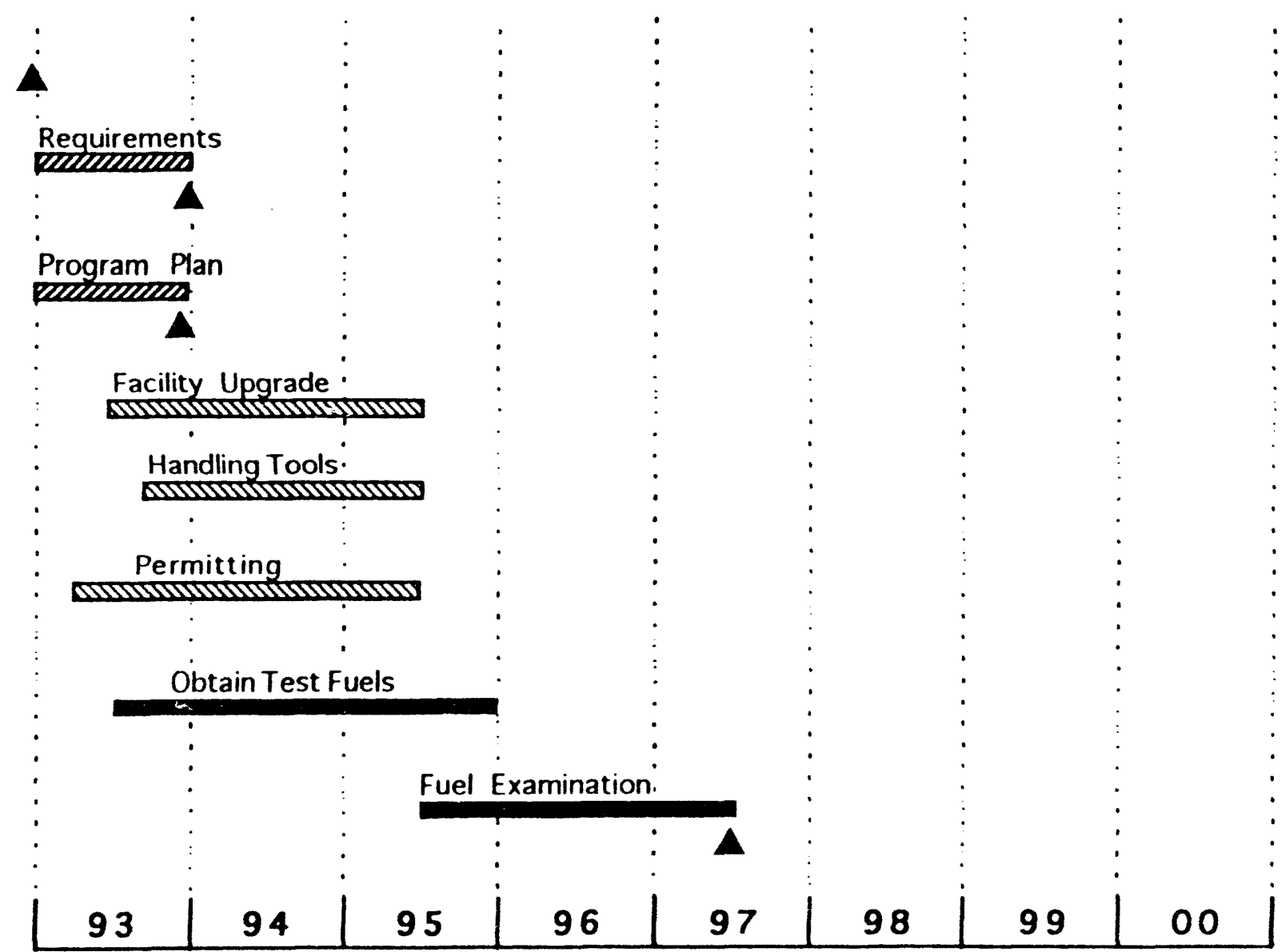

TIME IN FISCAL YEARS

Figure 4.3 SPENT FUEL INSPECTION/EXAMINATION

CLB-9/22/92 DEVELOPMENT \& ENGINEERING SCHEDULE -- SPENT GRAPHITE FUEL CONDITIONING 


\subsubsection{Functional Description}

A shipping cask will be moved into cell and the fuel removed. The fuel block will be loaded into the shredder. The shredder will remotely reduce the fuel size, and either collect shredded material in temporary hopper or feed directly into graphite burner. Storage and transfer of shredded material needs to be developed.

\subsubsection{Prior Development}

A variety of commercial shredding machinery is available, with different methods used to shred a variety of materials into myriad sizes and shapes. Shredders have been developed and tested for hot cell operations in nuclear facilities. Shredding of unirradiated or spent graphite fuel blocks has not been done.

\subsubsection{Technical Needs Summary}

Development activities for this task should address the following technical issues:

1. A shredder must be identified and either purchased or developed in-house. Equipment must be reliable and provide controlled-rate feeding of blocks and discharge of graphite and fuel particles.

2. Develop remote techniques to operate and maintain shredder. Remote maintenance is a high priority requirement. Jaming of the shredder should be anticipated, and preventive actions planned and tested in advance.

3. Develop a remote inspection capability to use in trouble-shooting of shredder. Otherwise, time-consuming decontamination will slow production severely. Remote replacement is to be preferred over in-place maintenance efforts.

4. Develop methods and procure equipment to handle spent blocks prior to shredding and to handle shredded material prior to the next operation.

\subsubsection{Major Development Risks}

Long-term reliability of operation of mechanical equipment in a hot cell is a high risk concern. Remote maintainability in a hot-cell is a design requirement. Questions on locating shredder gearboxes and drive motors either in the hot cell or outside must be addressed. Additionally, since shredders generally are not available in criticality safe configurations, operational parameters and procedures must address this risk. 


\subsubsection{Recommended Development Facilities}

Cold pilot plant facilities at the ICPP will be used. Hot cell facilities exist at TAN or at EBR-II may be available for use in this development effort. The cell must be large enough to contain the shredder and arranged in such a way that maintenance is as simple as possible. Cask unloading, shredder feeding, and handling of material after shredding will be addressed.

\subsubsection{Development Schedule}

Proof-of-concept testing by a commercial shredder manufacturer (Shred Pax Corp.) began during September 1992, and will be completed by March 1993. Based on success and results of these tests, design criteria for a full scale, remotely operated shredder will be prepared. Conceptual and procurement of this shredder for a second phase of full scale tests will begin, and follow the schedule in Figure 4.4.1. Funding and resource requirements for this task are estimated in the Appendix, WBS \#5.1.

\subsubsection{Integration With Other Tasks}

This task must be coordinated with other component development work for either graphite burning or direct disposal of shredded particles.

\subsubsection{References}

None.

\subsubsection{GRAPHITE BURNING}

(A. P. Pinto)

\subsubsection{Objective}

Develop and demonstrate the techniques and equipment for burning graphite from spent graphite fuel elements.

Development Priority: High

\subsubsection{Functional Description}

The two primary alternatives for graphite burning are the fluidized bed burner and the shaft furnace. An evaluation of alternative burning methods will be studied, e.g., burning of uncrushed fuel elements, partial burning to facilitate mechanical disassembly, and selective burning of only the fuel rod matrix. Graphite will be burned at elevated temperatures $\left(>700^{\circ} \mathrm{C}\right)$, after preheating to ignition temperature. The inlet combustion gas will be assumed to be either pure oxygen or enriched atmospheric air. Fuel and fertile particles will be recovered in the ash. The equipment will be critically favorable by geometry. 


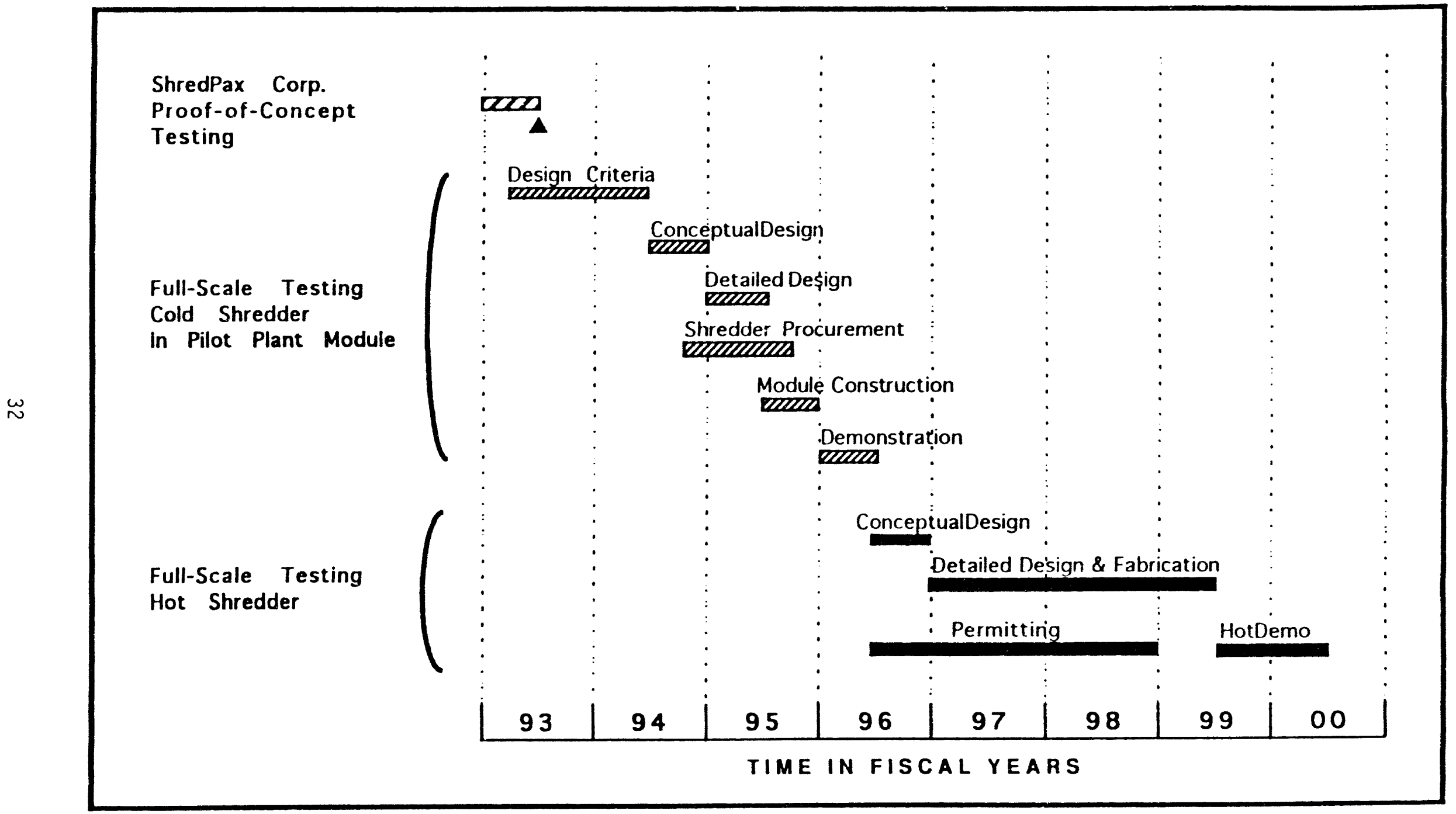

Figure 4.4.1 FUEL SIZE REDUCTION

CLB- $9 / 22 / 92$ DEVELOPMENT \& ENGINEERING SCHEDULE - SPENT GRAPHITE FUEL CONDITIONING 


\subsubsection{Prior Development}

Extensive information is available concerning combustion of graphite-based nuclear fuel components. Successful combustion of irradiated graphite fuels has been demonstrated for Rover fuels at the INEL, and for AVR pebble bed fuel in FRG's JUPITER hot prototype facility. Extensive cold component development work for HTGR spent fuel reprocessing was performed in pilot plant facilities at General Atomics Company in during the $1970 \mathrm{~s}$ and early 1980s. Work at these facilities demonstrated crushed, whole element burning followed by crushed particle burning in a separate secondary burner. Successful burning of uncrushed fuel elements and selective burning of only desired portions of fuel elements has not been demonstrated.

\subsubsection{Technical Needs Summary}

Development activities for this task should address the following technical issues:

1) Size of equipment needed to give required throughput and to meet criticality safety requirements.

2) Develop techniques and designs to extend burner life and reduce burner failures from thermal cycling, corrosion, and erosion.

3) Develop and improve methods to provide and augment thermal energy during startup and "tail burning".

4) Investigate feasibility of using ceramic components to enhance burner safety, reliability, and lifetime.

5) Develop improved combustion monitoring and control systems to allow effective "feed-forward" control of burner operations.

6) Develop and demonstrate capability for continuous steady-state combustion of fuel materials containing high fractions of graphite and heavy metal fines.

7) Develop and demonstrate equipment and techniques for remote operation, maintenance, repair, and replacement of complex burner systems and components. 


\subsubsection{Major Development Risks}

Research and development to date has shown that fluidized bed combustion of irradiated graphite based fuels is feasible. Major questions remain, however, concerning safety, reliability, and life of these burner systems. Remaining development requires numerous and extensive engineering and comparative studies, each having little development risk. Failure to perform these studies, however, may result in system designs that are capable of meeting production requirements, but are burdened with excessive safety, licensing, and economic penalties.

The main advantage of the fluidized bed furnace is its high level of technology development and demonstration within the nuclear industry. The turbulence in the fluidized bed will serve to disperse the heat generated from the graphite combustion, i.e., eliminates hot spots within the burner. One disadvantage is the need for equipment such as the fluidizing air blowers and additional instrumentation associated with monitoring the fluidizing bed.

The shaft furnace also has a high level of commercial technology, but not within the spent fuel processing industry. The off-gas can be used to preheat the graphite to be successively burned. This concept may be simpler and may require less equipment than the fluidized bed burner concept. However, specially designed and strategically placed combustion gas inlet nozzles will be required. The combustion gas would have to be introduced in such a fashion that it would preciude bridging of the graphite around the burning zone and hot spots near the vessel walls.

An evaluation of other alternatives will examine partial burning to facilitate mechanical disassembly, burning of whole uncrushed fuel elements, selective burning of only the fuel rod matrix, and other combustion gases besides oxygen. Based on the results of the evaluation, tasks to be performed later may be modified.

\subsubsection{Recommended Development Facilities}

Most of this task requires cold component development which may be accomplished in pilot plant facilities. Studies of the generation, transport, and fate of semivolatile fission products are included in section 4.4 .3 . However, radioactive studies will require a burner off-gas source which implies development of a semi-scale hot cell burner.

Also included in the pilot facilities may be a shaft furnace for investigating the burning of uncrushed fuel elements. Initial testing could be done on half scale graphite blocks used to simulate fuel elements. Since a fluidized bed furnace method has already been demonstrated, it remains the primary choice unless another technology soon becomes superior. 


\subsubsection{Development Schedule}

A summary schedule for this task is shown in Figure 4.4.2. Identification and evaluation of alternatives for burning of bulk graphite will be completed during FY 1993. Significant effort will be made on the two primary burning alternatives, a fluidized bed burning and a shaft furnace.

A commercial contract proposal for pilot plant scale construction and testing will be prepared and issued for bid, with bid acceptance scheduled for mid-FY 1993. Design of the shaft furnace will follow promptly, with completion of construction by mid-FY 1994. Adequate testing should be completed to permit a selection of preferred burner designs by the end of FY 1994.

The fluidized bed burner has received much further development with in the nuclear industry. A detailed conceptual design will be prepared during FY 1993 for comparison with the shaft furnace technology.

With selection of a preferred burner design and technology, a full-scale pilot plant will be sought. As shown in Figure 4.4.2, a three year period is scheduled for conceptual design, detailed design and permitting, and construction. Demonstration testing by FY 1998 is desired to support hot scale demonstration of selected graphite fuel conditioning process components in FY 1999. Funding and resource requirements for this task and off-gas cleanup (Section 4.4.3) are estimated in the Appendix, WBS $\# 5.2$.

\subsubsection{Integration with Other Tasks}

The graphite burning task has to be integrated with the mechanical disassembly tasks. Also, regulatory requirements will impact the development of the graphite burning task. An evaluation will be made to determine whether the carbon dioxide from the burning will be capable of being discharged to the atmosphere or will it have to be converted to calcium carbonate and disposed in a waste burial area.

\subsubsection{References}

1. Rickman, W. S., Process Development Report - 0.20-m Primary Burner System, GAA-A-15088, General Atomics Company, September 1978.

2. Young, D. T., Process Development Report: 0.40-m Primary Burner System, GA-A-14816, General Atomics Company, Apri1 1978

3. Rickman, W. S. Process Development Report - 0.20-m Secondary Burner System, GA-A-14542, General Atomics Company, September 1977. 


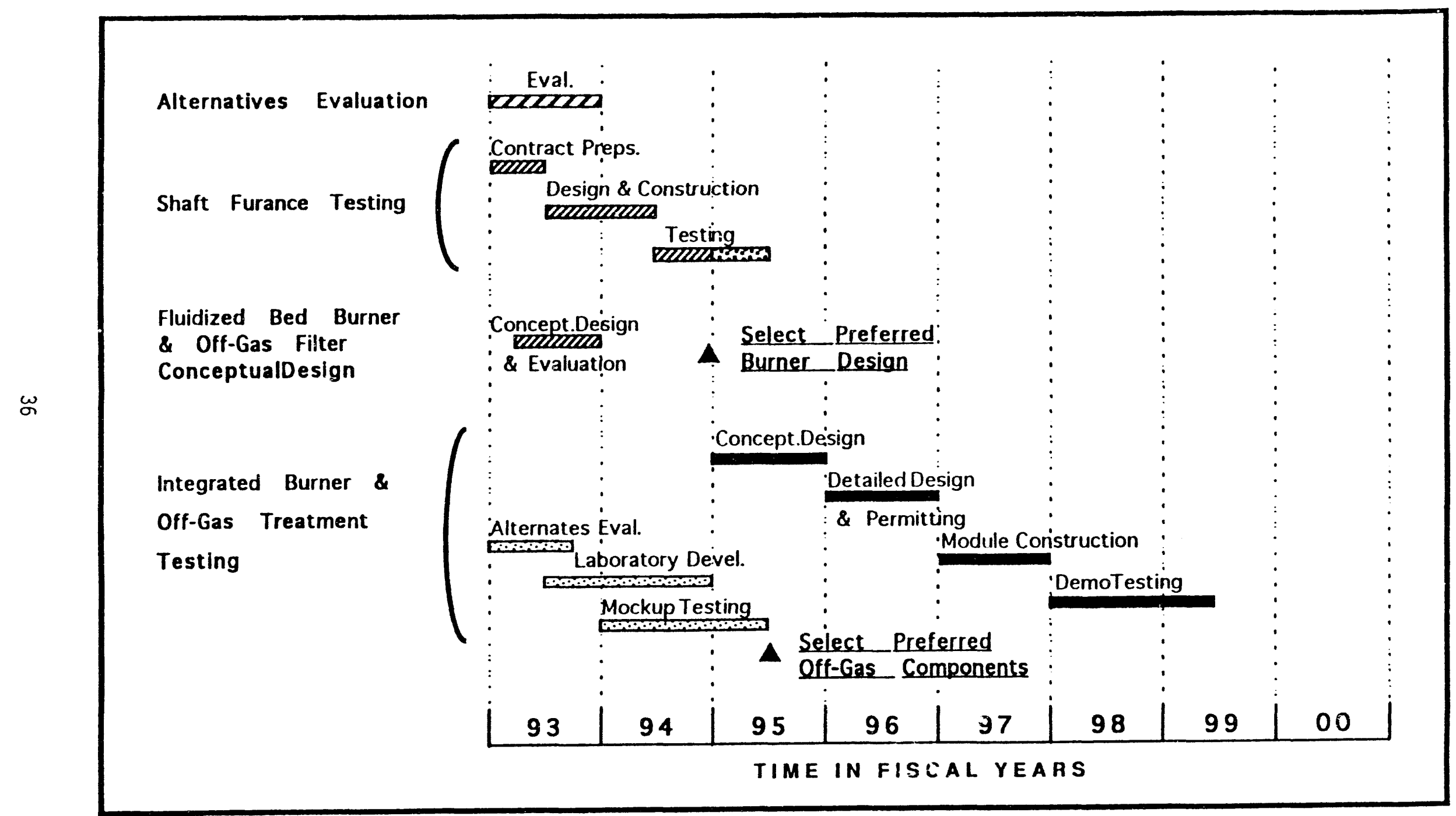

Figure 4.4.2 GRAPHITE BURNER \& OFF-GAS TREATMENT DEVELOPMENT \& ENGINEERING SCHEDULE -- SPENT GRAPHITE FUEL CONDITIONING 


\subsubsection{BURNER OFF-GAS TREATMENT}

(D. L. Fillmore)

\subsubsection{Objective}

Develop processes and equipment for the treatment of graphite burner off-gas (BOG).

Development Priority: High

\subsubsection{Functional Description}

The BOG will be contained, transferred, and cooled. Semi-volatile fission products (SVFP) will be removed for disposal. Entrained particulate will be removed. Carbon monoxide will be oxidized to carbon dioxide. Tritium will be oxidized to water, removed from BOG, and processed for disposal. Carbon-14 as $\mathrm{CaCO}_{3}$ will be removed (if required) and prepared for shallow land burial.

\subsubsection{Prior Development}

Individual elements of this task have been developed as part of the overall HTGR development programs in the US, UK, and FRG during the 1970s and early 1980s. The most integrated and complete development program resulted in construction and limited operation of a 1/10-scale, integrated BOG processing train at General Atomic Company. Using a cold synthetic BOG as feedstock, this system demonstrated all BOG decontamination functions except removal of SVFP. Individual components functioned well during the testing, but integrated system operation was difficult, unreliable, and maintenance intensive. Virtually no previous work has been done to develop engineering scale fixation and disposal technologies for BOG treatment wastes. Limited semi-scale work was done at Oak Ridge National Laboratory to obtain data to support flowsheet development for carbonate fixation of carbon-14.

\subsubsection{Technical Needs Summary}

Development activities for this task should address the following technical issues:

1) Characterize volatile and semivolatile fission product properties, including generation rates as a function of burner operating parameters. Al so characterize transport, condensation, absorption, and plate out behavior in the BOG system.

2) Develop and demonstrate a reliable, effective SVFP removal system.

3) Develop and demonstrate a volatile fission product and particulate removal system which functions reliably and effectively. 
4) Develop an integrated system for removal of all undesirable emissions including a removal sequence for optimum operation.

5) Develop minimum volume, combined fixation and disposal technologies for BOG treatment wastes, including condensed SVFP, carbonate sludge, ion exchange resin, molecular sieves, and filters.

6) Develop reliable remote sampling, analysis, and monitoring equipment for BOG to ensure effective process control and environmental compliance.

\subsubsection{Major Development Risks}

Previous development work has demonstrated the technical feasibility of employing successive unit operations to remove specific components from the BOG. Use of multiple unit operations to process a gas streant results in high overall pressure drop and a need for in-cell prime movers for the gas stream. Safety and environmental requirements will likely mandate use of backup systems for BOG treatment and monitoring. Some of the BOG components will interfere with the removal mechanism of other components, and the component sequencing will be very important. Each unit operation generates a given volume of a unique waste. Most of the BOG treatment operations require periodic replenishment of either solid media or process reagents. Thus, the result of this development task must be the design of an extremely complex, well integrated, and very reliable system employing novel technologies. The major risk is that the BOG treatment development will need the design and operating parameters of the burners, and specific design can not be completed until the burners are defined. This could potentially delay the final design and it could delay the overall program.

\subsubsection{Recommended Development Facilities}

Mechanical and glass shop facilities will be required to construct and assemble experiments for testing. Cold laboratory facilities will be required to test and select candidate scrubbers, catalysts, resins, sorbents, and molecular sieves. The characterization of the SVFP properties in the BOG as well as carbonate chemistry and kinetic studies are also candidates for cold laboratory development. Both cold and hot laboratory facilities will be required to complete SVFP removal development. Component development and testing will require engineering scaled cold pilot plant facilities. Finally, integrated testing and development of remote features will require cold prototype and mockup facilities. 


\subsubsection{Development Schedule}

Alternatives for the various $B O G$ cleanup requirements will be evaluated during FY 1993 (see Figure 4.4.2). Laboratory development for some cleanup systems will begin by mid-FY 1993, but only on those wherever available technology lacking. Markup testing of criterial items should begin in FY 1994. Resource and funding requirements for these tasks are enclosed in Appendix WBS \#2.

\subsubsection{Integration with Other Tasks}

This is a critical task, closely linked to burner development. BOG treatment represents a major portion of the headend flowsheet, and is the most complex and critical environmental control system in the facilits design. This task requires an early start and a high priority. Adequate BOG treatment and waste fixation must be demonstrated prior to headend facility design.

\subsubsection{References}

1. C. L. Bendixsen et al., Preliminary Development and Engineering Plan for Processing Fort St. Vrain Fuel, WIN-300, January 1990, WINCO

\subsubsection{ASH PACKAGING AND ACCOUNTABILITY}

(M. B. Phillips)

\subsubsection{Objective}

Develop and demonstrate remote techniques, materials, and equipment to accomplish burner ash encapsulation, packaging, storage, handling, and accountability functions prior to ash transfer to either engineered storage or dissolution processing. Mixed fission product activity and heavy metal content must be monitored during this process.

Develop and demonstrate techniques and technology to store ash prior to either direct disposal or chemical processing. Storage will require consideration of radiation fields and also handling into and out of storage.

Develop and demonstrate loading of ash containers into shipping containers, feasibility of shipping containers to repository, and unloading containers at destination.

Development Priority: Low 


\subsubsection{Functional Description}

Ash from the graphite burner will be cooled and packaged in metal canisters. Fission product activity and heavy metal content of ash will be determined. The fuel canister will be placed in safe, interim storage. Storage temperature will be monitored with cooling as necessary.

\subsubsection{Prior Development}

Remote canning and sealing processes have been developed and adapted for use in the nuclear industry. Available remote canning processes may be suitable for ash sent to engineered storage. Remote solids monitoring development work historically has focused on providing measurements to confirm that contamination is below a specified low value. If graphite burner ash is to be sent to either a repository or engineered storage, its heavy metal content and composition must be known and verified. This requires modifications to existing, and development of new, techniques for remote non-destructive assay (NDA) of heavy metals at very high loadings.

\subsubsection{Technical Needs Summary}

Development activities for this task should address the following technical issues:

1. Develop ash packaging specifications appropriate for storage, transportation, repository disposal and for dissolution and separations processing.

2. Modify or develop neutron interrogation and also high-resolution, segmented gamma scanning techniques for applications involving high heavy metal loadings and high mixed fission product activity.

3. Develop equipment and technology to decontaminate fuel containers, load them into shipping casks, and load the casks onto a transport vehicle.

\subsubsection{Major Development Risks}

Ash packaging is a well developed technology and presents no significant development risks. Accountability of heavy metals and hazardous materials will require development and does present a risk.

\subsubsection{Recommended Development Facilities}

Hot cell facilities will be required to prepare standards, calibrate, and test NDA equipment. Cold pilot plant component test facilities will be required to develop and demonstrate ash packaging and container sealing operations. They will also be raquired to contain the canisters and dissipate any decay heat generated in the fuel. 
Equipment for loading fuel canisters into shipping casks and for loading shipping casks onto transport vehicles will have to be specified and/or developed.

\subsubsection{Development Schedule}

An evaluation of alternatives and selection of criteria for each packaging and accountability will be completed during FY 1993. Primary development effort will be focused in the accountability technology. A conceptual design of an accounting technology will begin in FY 1997 and will be completed in FY 1994. Although an earlier demonstration on cold units will occur, the final demonstration testing will not be sought until FY 1997 (see Figure 4.4.4). Funding and resource requirements for this task are estimated in the Appendix, WBS \#5.3, which will also include the solids transport and handling task (Section 4.4.5).

\subsubsection{Integration With Other Tasks}

This task requires interface with the burner and dissolver development tasks. It is a low risk task with only minor process impacts. This development task should be scheduled to take advantage of cold ash available during pilot plant burner testing. Sources of irradiated ash material for monitor testing have yet to be identified. This task also requires interface with the ash encapsulation, ash shipping, and ash processing tasks.

\subsubsection{References}

1. C. L. Bendixsen, A. L. 01 son, B. R. Wheeler, "Preliminary Development and Engineering Plan for Processing Fort St. Vrain Fuel", WINCO.

\subsubsection{RADIOACTIVE SOLIDS TRANSPORT AND HANDLING}

(M. B. Phillips)

\subsubsection{Objective}

Develop design data, techniques, and equipment for remote transfer, measurement, and handling of radioactive particulates, including graphite dust, fuel rods, fuel element fragments, crushed fuel rods, fuel particles, and burner ash.

DEVELOPMENT PRIORITY: MediUM

\subsubsection{Functional Description}

Process activities herein include: containing particulates; transfering particulates; weighing particulates; feeding particulates to process equipment; discharging particulates from process equipment; plus controlling and regulating particle transfer, feed, and discharge rates. 


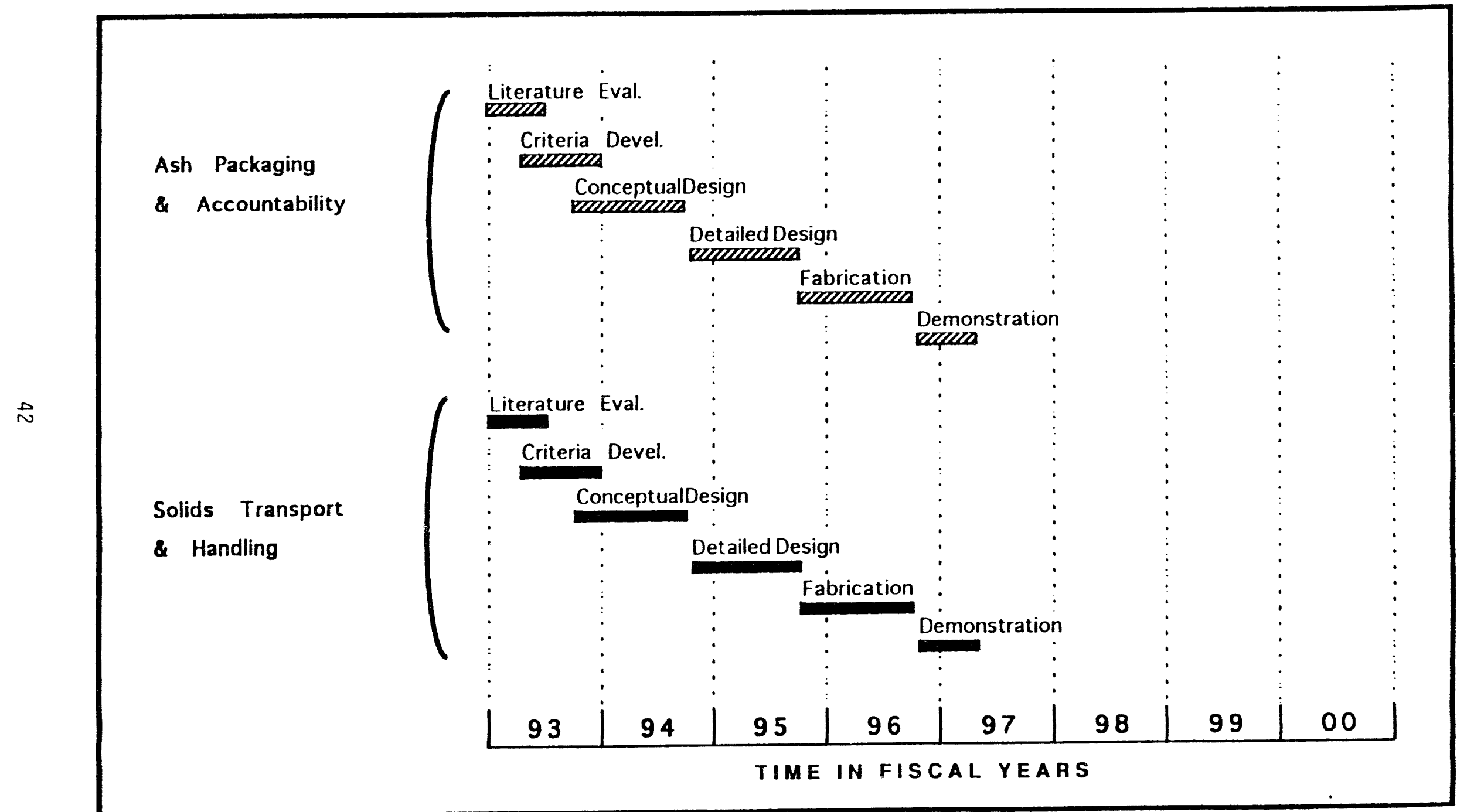

Figure 4.4.4 ASH PACKAGING \& SOLIDS TRANSPORT

CLB-9/22/92 DEVELOPMENT \& ENGINEERING SCHEDULE - SPENT GRAPHITE FUEL CONDITIONING 


\subsubsection{Prior Development}

Handling and transfer of many headend radioactive particulates have been demonstrated during processing of Rover fuels at the INEL and during operation of the JUPITER facility at Kernforschungsanlage in Germany. Extensive cold component testing for headend particulate handling and transfer has been done at General Atomic Company in San Diego. Although these programs have produced a substantial design data base to support this development task, additional work is required.

\subsubsection{Technical Needs Summary}

Development activities for this task should address the following technical issues:

1. Determine the pneumatic transport characteristics for all particle types including: transport, saltation, and re-entrainment velocities as a function of line size; minimum safe transport velocity; and component abrasion and line erosion behavior.

2. Develop automatic controls and equipment to diagnose, regulate, and optimize pneumatic transport of particulates.

3. Develop reliable components and equipment to provide controlled-rate feeding and discharge of particulates from process and storage equipment.

4. Develop remote techniques to accurately determine the rate and total mass of particulates transferred.

5. Develop a materials properties data base for all particle types including: particle density, bulk and tap densities, angle of repose, cohesiveness, internal shear angle, and size distribution.

\subsubsection{Major Development Risks}

This development task primarily involves adaption, improvement, and optimization of demonstrated technology. Consequently, no major development risks are associated with this task.

\subsubsection{Recommended Development Facilities}

Cold engineering scale component development will be required to accomplish this task. No irradiated materials testing is anticipated. 


\subsubsection{Development Schedule}

A schedule for completion of this task is depicted in Figure 4.4.4. An identification of available technology will be followed by review of its applicability to FSV fuel particles and/or ash. This in turn will be followed, as needed, by design, fabrication, and testing of demonstrated engineering technology. The funding and resource requirements for this task are enclosed in the prior task, Section 4.4.4; see the Appendix, WBS $\# 5.3$

\subsubsection{Integration With Other Tasks}

This is a low risk development task with only minor flowsheet and process feasibility impacts. However, this task must be coordinated with other component development work for element disassembly and rod removal, fuel rod and particle crushing, fuel burning, and ash handling.

\subsubsection{References}

1. C. L. Bendixsen, A. L. Olson, B. R. Wheeler, "Preliminary Development and Engineering Plan for Processing Fort St. Vrain Fuel", WIN-300, January 1990, WINCO.

\subsection{PILOT PLANT TESTING OF EQUIPMENT AND PROCESS SYSTEMS}

(R. J. Kirkham)

\subsubsection{Objective}

Design and fabricate pilot plant and component subsystems to perform testing of disposal alternatives. Perform the required test work as needed.

Development Priority: High

\subsubsection{Functional Description}

Perform required laboratory test work in support of the graphite fuels disposal program. Design and fabricate the needed test modules and subcomponents for the multi-function pilot plant. Interface with the designers of the multi-function pilot plant to assure that the projected needs are met for the testing of the graphite fuels disposal alternatives.

\subsubsection{Prior Development}

Much effort has been made on projected needs in support of the Graphite Fuels Treatment Program. Pre-conceptual design criteria was prepared for a Graphite Fuels Pilot Plant Facility for the Graphite Fuels Treatment Program. This design criteria is now being used as a starting bases for a multi-function pilot plant design. 
This criteria did not, however, provide for testing of direct disposal a) ternatives. The direct disposal testing probably cannot be conducted in a multi-function pilot plant but will need special consideration.

\subsubsection{Technical Needs Summary}

The needs of pilot plant and subsystem testing will be dictated by decisions made in the preliminary evaluations and testing work. It is known that some test work will be required on the disposal packages. Testing will be done on rod and block separation, block shredding, graphite burning and offgas treatment, and packaging techniques.

The testing will be done from scoping of the projected alternatives through the final design verification of the selected alternatives. Test modules and full scale subsystems components will be designed, procured, and tested in later phases of the testing.

\subsubsection{Major Development Risks}

The risks involved in pilot plant design and operation are the same for any test program, 1) Obtaining the correct equipment, 2) conducting the test work with in the correct parameters in the plant or equipment design, 3) scaling the equipment to the chosen design, and 4) interpreting the test results correctly. Enough is understood about test work to mitigate these risks, if correct principles are applied and adequate data are taken. The risk is in the tendency to meet schedules or with the excitement of favorable results, that mitigating principles are not fully adhered to.

\subsubsection{Recommended Facilities}

Much of the test work will be done in the laboratories and the available on the new multi-function pilot plant. Some test work will be performed by contract by onsite and offsite contractors. Test facilities will be located or contracted as dictated by chosen alternatives.

\subsubsection{Development Schedule}

The testing schedule will follow on an as needed basis and will be dictated by selection of certain alternative conditioning schemes. The constructing of subsystem components will be early on offsite contracts and later on pilot plant modules the specific alternatives selected for final testing. (See Figure 4.5). Funding and resource requirements for this supporting task are estimated in the Appendix, WBS \#7.0. 


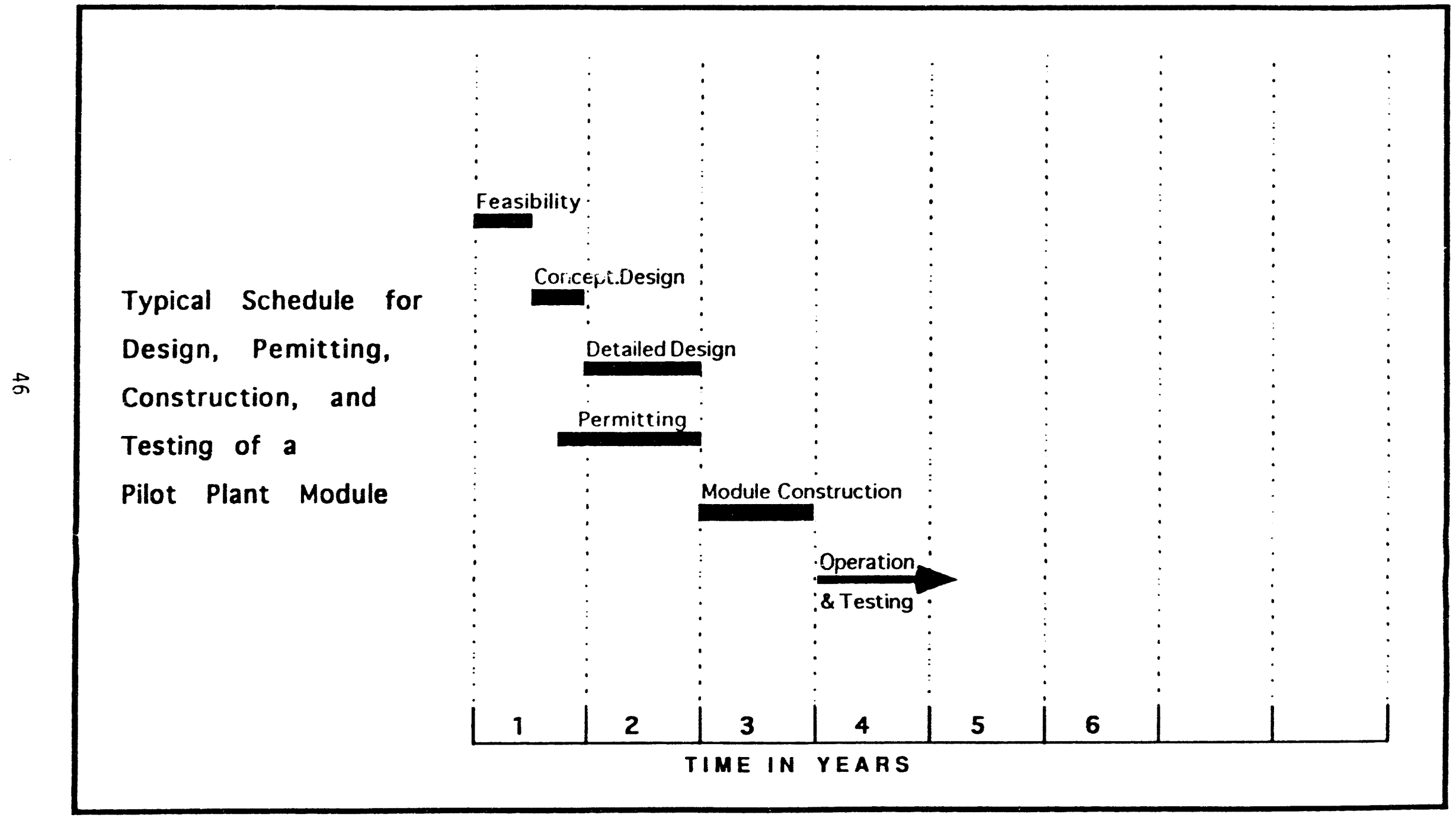

Figure 4.5 PILOT PLANT MODULES

CLB-9/24/92 DEVELOPMENT \& ENGINEERING SCHEDULE - SPENT GRAPHITE FUEL CONDITIONING 


\subsubsection{Integration with Other Tasks}

The test work is necessarily completely integrated with the entire development plan and will be sequenced with each decision made on the conditioning alternatives. The test work results are to be used to make many of the decisions.

\subsubsection{References}

None

\subsection{SYSTEMS EVALUATIONS}

(C. L. Bendixsen)

\subsubsection{Objective}

Perform comparative systems analyses on unique process steps to assess their benefits and risks, thus permitting choice of optimum fuei conditioning strategies.

Development Priority: High

\subsubsection{Functional Description}

Provide process and waste conditioning data to the Systems Analysis Section for their overall evaluation and modeling studies. Perform independent systems evaluations on unique and complex process steps or spent fuel conditioning options. Evaluate results and recommend optimum paths for efficient and timely spent graphite fuel conditioning.

\subsubsection{Prior Development}

The systems analysis approach has not been previously applied to the conditioning of spent graphite fuels. Several studies have been made on graphite fuel conditioning, often with specific disposal methods being strongly recommended. However, none of the studies have made the broader evaluation of options available to the systems evaluation methods.

\subsubsection{Development Needs}

A Systems Analysis Section has been established at the ICPP and the personnel are being trained in the analytical techniques and available computer models. Some personnel in the Graphite Fuels Conditioning Section will receive this same training. Computer systems and appropriate computer modeling software will be acquired. 


\subsubsection{Development Risks}

Training of personnel is important. Should the analysis techniques be misapplied, incorrect conclusions and recommendations will be the result, followed by incorrect and inefficient fuel conditioning processes being developed. As with all process modeling, too much complexity should be avoided. Excessive complexity generally leads to untimely results and wasted efforts.

\subsubsection{Recommended Development Facilities}

No new or modified facilities are needed for this task

\subsubsection{Development Schedule}

This will be a continuing level of effort throughout the Graphite Fuels Conditioning Program as estimated in the Appendix WBS \#2.0.

\subsubsection{Integration with Other Tasks}

The systems evaluation effort will support, to a greater or lesser extent, each of the other tasks in this program. The analysis effort should be a parallel effort, and will not restrict the progress of any task.

\subsubsection{References}

None

\subsection{PROGRAM CONTROL}

(C. L. Bendixsen)

\subsubsection{Objective}

Perform program control activities related to the Graphite Fuels Conditioning Program.

\subsubsection{Functional Description}

Perform personnel management. Forecast and control budgets. Schedule activities and establish milestones. Prepare program plans. Prepare periodic reports for company management and DOE personnel.

\subsubsection{Prior Development}

Program control will be performed according to previously prepared program plans and DOE guidelines.

\subsubsection{Technical Needs Summary}

None 


\subsubsection{Major Development Risks}

Not applicable.

\subsubsection{Recommended Development Facilities}

Not applicable.

\subsubsection{Development Schedule}

This will be a continuing level of effort throughout the Graphite Fuels Conditioning Program, as estimated in the Appendix, WBS \#1.0.

\subsubsection{Integration with Other Tasks}

This effort will support each of the other tasks in this program and must enhance the progress of each.

\subsubsection{References}

None

\subsection{PROCESSING FACILITIES}

(C. L. Bendixsen)

\subsubsection{Objective}

Provide facilities for interim storage and/or spent graphite fuel conditioning prior to transfer to a long-term geologic repositor..

\subsubsection{Functional Description}

Provide design data and criteria to Projects Department as needed for a interini storage facility and/or spent fuel conditioning facility.

\subsubsection{Prior Development}

The Irradiated Fuel Storage Facility (IFSF) at the ICPP is a dry facility presently used for storing spent graphite fuels (FSVR and Peach Bottom). The IFSF presently meets environmental and regulatory limits for dry storage of irradiated fuel. Processing of irradiated Rover fuels has been accomplished at the ICPP, but has not been done for FSVR and Peach Bottom spent fuels. Facilities proposed for HTGR fuel processing have not proceeded beyond the conceptual design phase, but considerable development and cold testing of candidate processes has been accomplished.

\subsubsection{Technical Needs Summary}

New facility designs are to be made based on re-evaluation of past development and on development of new, or revised, process steps identified in earlier sections of this report. 


\subsubsection{Major Development Risks}

The desired schedule for design and construction of interim storage and/or conditioning facilities allows for limited new development. This development must proceed with dispatch and thoroughness such that facility and process design criteria may be confidently selected. Adequate budgeting for the development tasks will significantly influence and/or limit the progress towards selection of design criteria.

\subsubsection{Recommended Development Facilities}

Although the IFSF is operating at the ICPP, a re-evaluation of the facility for interim storage of conditioned spent graphite fuels will be required. Should the IFSF not meet new interim storage requirements, ar new interim facility will need to be designed and constructed. Interim storage of the conditioned spent fuel will be required until the fuel may be transferred to a long-term geologic repository.

\subsubsection{Development Schedule}

A fuel conditioning (or treatment) facility is presently planned as a FY 2000 project (ie, funding for detailed design is available). A FY 2000 project will require that feasibility studies begin as early as FY 1995 (see Figure 1.2). Funding and resource requirements to support feasibility and conceptual design studies are estimated in the Appendix, WBS \#8.0 and 9.0 .

\subsubsection{Integration with Other Tasks}

This effort will closely integrated with completion of process development and demonstration activities for defining the spent fuel conditioning steps.

\subsubsection{References}

None 


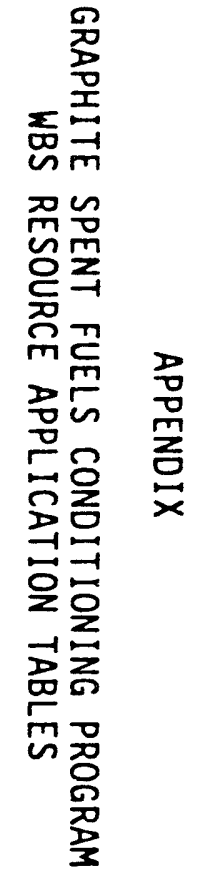




\section{Graphite Spent Fuels Conditioning Program}

Work Breakdown Structure -- Manpower \& Other Cost Estimates

\section{OBJECTIVE: Develop conditioning methods for spent graphite fuels}

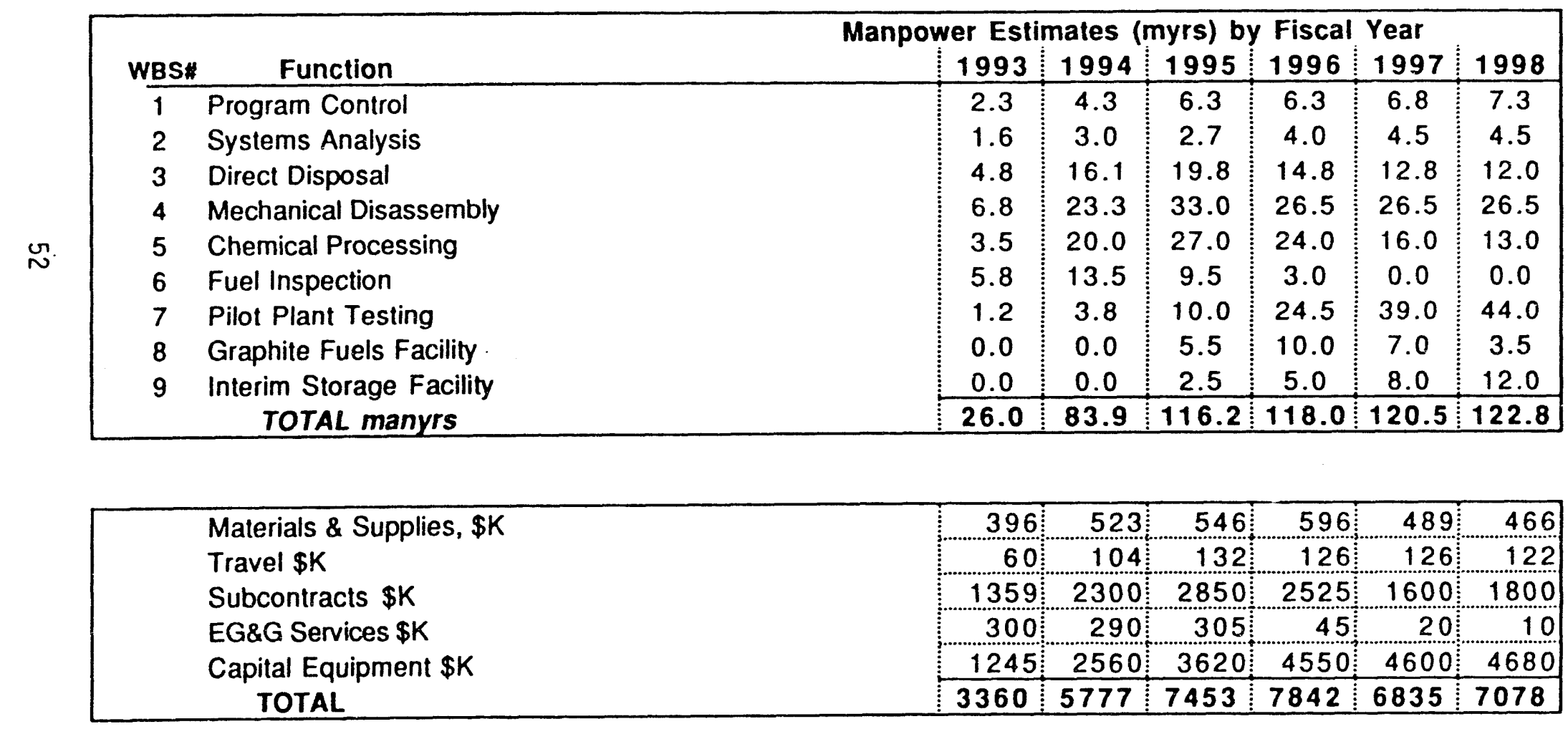




\section{RESOURCE APPLCATION WORKTABLE}

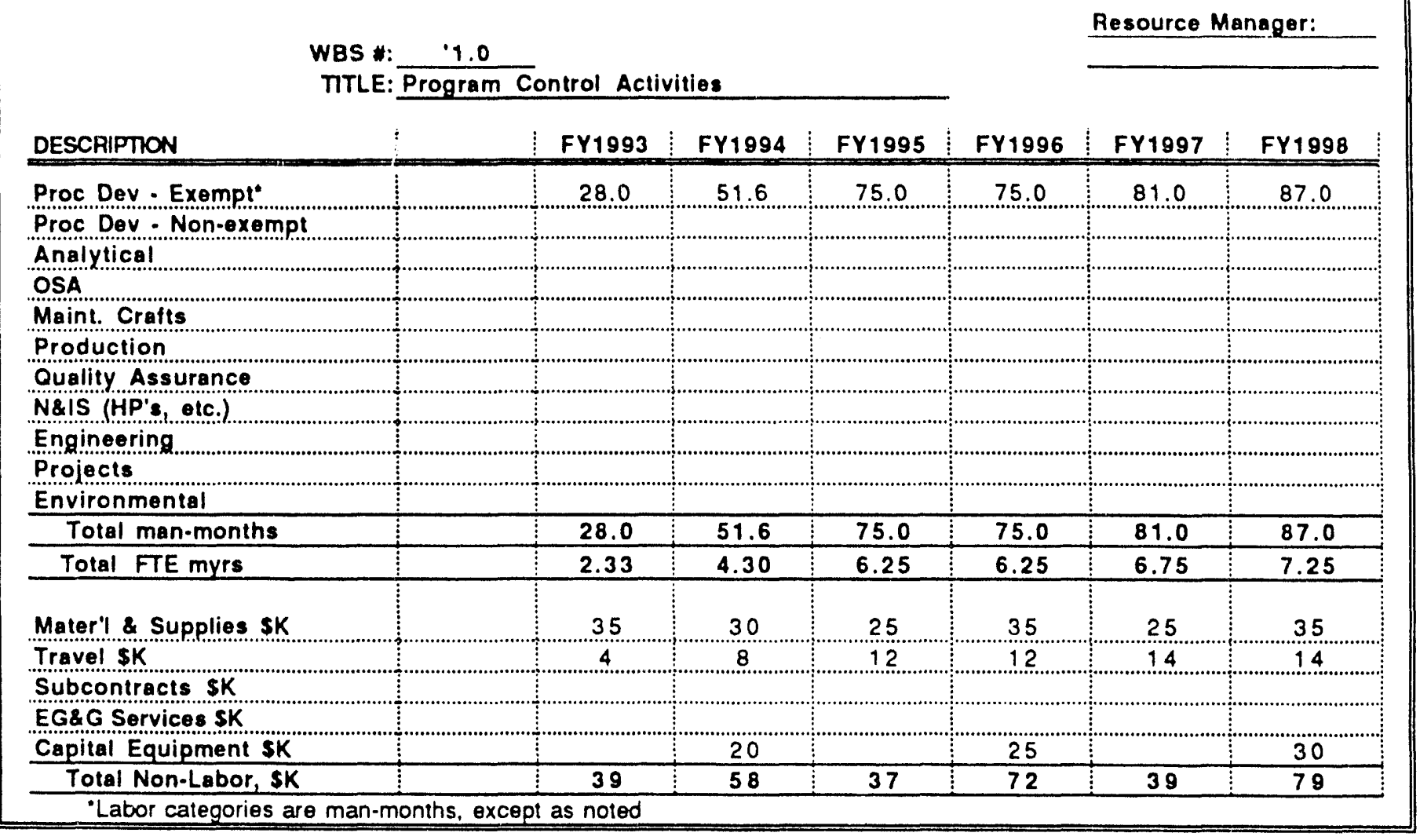

\section{RESOURCE APPLICATION WORKTABLE}

WBS : $\quad 1.2$

Resource Manager:

TITLE: Technical Bases Documents

\begin{tabular}{|c|c|c|c|c|c|c|}
\hline DESCRIPION & FY1993 & FY1994 & FY1995 & FY1996 & FY1997 & FY1998 \\
\hline Proc Dev - Exempt" & 13.0 & 15.6 & 23.0 & 23.0 & 25.0 & 27.0 \\
\hline \multicolumn{7}{|l|}{ Proc Dev - Non-exempt } \\
\hline \multicolumn{7}{|l|}{ Analytical } \\
\hline \multicolumn{7}{|l|}{ OSA } \\
\hline \multicolumn{7}{|l|}{ Maint. Crafts } \\
\hline \multicolumn{7}{|l|}{ Production } \\
\hline \multicolumn{7}{|l|}{ Quality Assurance } \\
\hline \multicolumn{7}{|l|}{ N\&IS (HP's, etc.) } \\
\hline \multicolumn{7}{|l|}{ Engineering } \\
\hline \multicolumn{7}{|l|}{ Projects } \\
\hline \multicolumn{7}{|l|}{ Environmental } \\
\hline Total man-months & 13.0 & 15.6 & 23.0 & 23.0 & 25.0 & 27.0 \\
\hline Total FTE myrs & 1.08 & 1.30 & 1.92 & 1.92 & 2.08 & 2.25 \\
\hline Mater'l \& Supplies SK & 5 & 5 & 5 & 5 & 5 & 5 \\
\hline Travel \$K & & 2 & 4 & 4 & 4. & 4 \\
\hline \multicolumn{7}{|l|}{ Subcontracts sk } \\
\hline \multicolumn{7}{|l|}{ EG\&G Services \$K } \\
\hline Capital Eguipment sk & & & & & & \\
\hline Total Non-Labor, SK & 5 & 7 & 9 & 9 & 9 & 9 \\
\hline
\end{tabular}




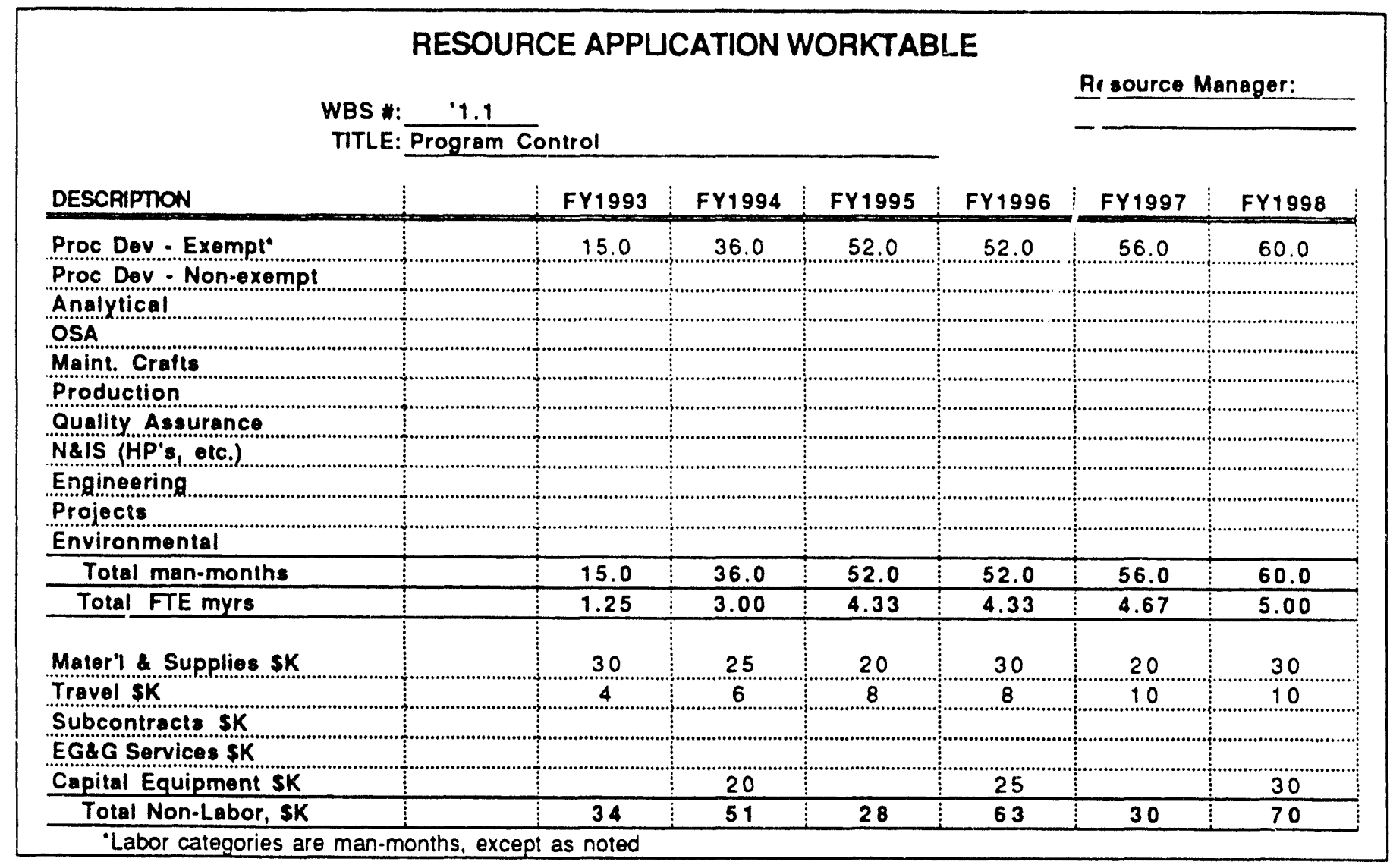




\section{RESOURCE APPLICATION WORKTABLE}

WBS *: $\quad 2.0$

Resource Manager:

TITLE: Systems Evaluations

\begin{tabular}{|c|c|c|c|c|c|c|}
\hline DESCRIPTION & FY1993 & FY1994 & FY1995 & FY1996 & FY1997 & FY1998 \\
\hline Proc Dev - Exempt* & 19.0 & 36.0 & 32.0 & 48.0 & 54.0 & 54.0 \\
\hline \multicolumn{7}{|l|}{ Proc Dev - Non-exempt } \\
\hline \multicolumn{7}{|l|}{ Analytical } \\
\hline \multicolumn{7}{|l|}{ OSA } \\
\hline \multicolumn{7}{|l|}{ Maint. Crafts } \\
\hline \multicolumn{7}{|l|}{ Production } \\
\hline \multicolumn{7}{|l|}{ Quality Assurance } \\
\hline \multicolumn{7}{|l|}{ N\&is (HP's, otc.) } \\
\hline \multicolumn{7}{|l|}{ Engineering } \\
\hline \multicolumn{7}{|l|}{ Projects } \\
\hline \multicolumn{7}{|l|}{ Environmental } \\
\hline Total man-months & 19.0 & 36.0 & 32.0 & 48.0 & 54.0 & 54.0 \\
\hline Total FTE myrs & 1.58 & 3.00 & 2.67 & 4.00 & 4.50 & 4.50 \\
\hline Mater'l \& Supplies SK & 36 & 12 & 5 & 15 & 10 & 15 \\
\hline Travel SK & 4 & 6 & 4 & 6 & 6 & 6 \\
\hline \multicolumn{7}{|l|}{ Subcontracts \$K } \\
\hline \multicolumn{7}{|l|}{ EG\&G Services \$K } \\
\hline Capital Equipment sk & 20 & 25 & & 25 & & 25 \\
\hline Total Non-Labor, SK & 60 & 43 & 9 & 46 & 16 & 46 \\
\hline
\end{tabular}

\section{RESOURCE APPLICATION WORKTABLE}

WBS * $\quad 2.1$

Resource Manager:

TITLE: Supporting Criteria to Systems Analysis Group

\begin{tabular}{|c|c|c|c|c|c|c|}
\hline DESCRIPTION & FY1993 & FY1994 & FY1995 & FY1996 & FY 1997 & FY1998 \\
\hline Proc Dev - Exempt" & 4.0 & 4.0 & & & & \\
\hline \multicolumn{7}{|l|}{ Proc Dev - Non-exempt } \\
\hline \multicolumn{7}{|l|}{ OSA } \\
\hline \multicolumn{7}{|l|}{ Maint. Crafts } \\
\hline \multicolumn{7}{|l|}{ Production } \\
\hline \multicolumn{7}{|l|}{ Quality Assurance } \\
\hline \multicolumn{7}{|l|}{ N\&IS (HP's, etc.) } \\
\hline \multicolumn{7}{|l|}{ Enginesring } \\
\hline \multicolumn{7}{|l|}{ Proje is } \\
\hline \multicolumn{7}{|l|}{ Environmental } \\
\hline Total man-months & 4.0 & 4.0 & & & & \\
\hline Total FTE myrs & 0.33 & 0.33 & & & & \\
\hline \multicolumn{7}{|l|}{ Mater'l \& Supplies \$K } \\
\hline \multicolumn{7}{|l|}{ Travel \$K } \\
\hline \multicolumn{7}{|l|}{ Subcontracts $\$ K$} \\
\hline \multicolumn{7}{|l|}{ EG\&G Services \$K } \\
\hline Capital Equipment SK & & & & & & \\
\hline Total Non-Labor, SK & 1 & 4 & & & & \\
\hline
\end{tabular}




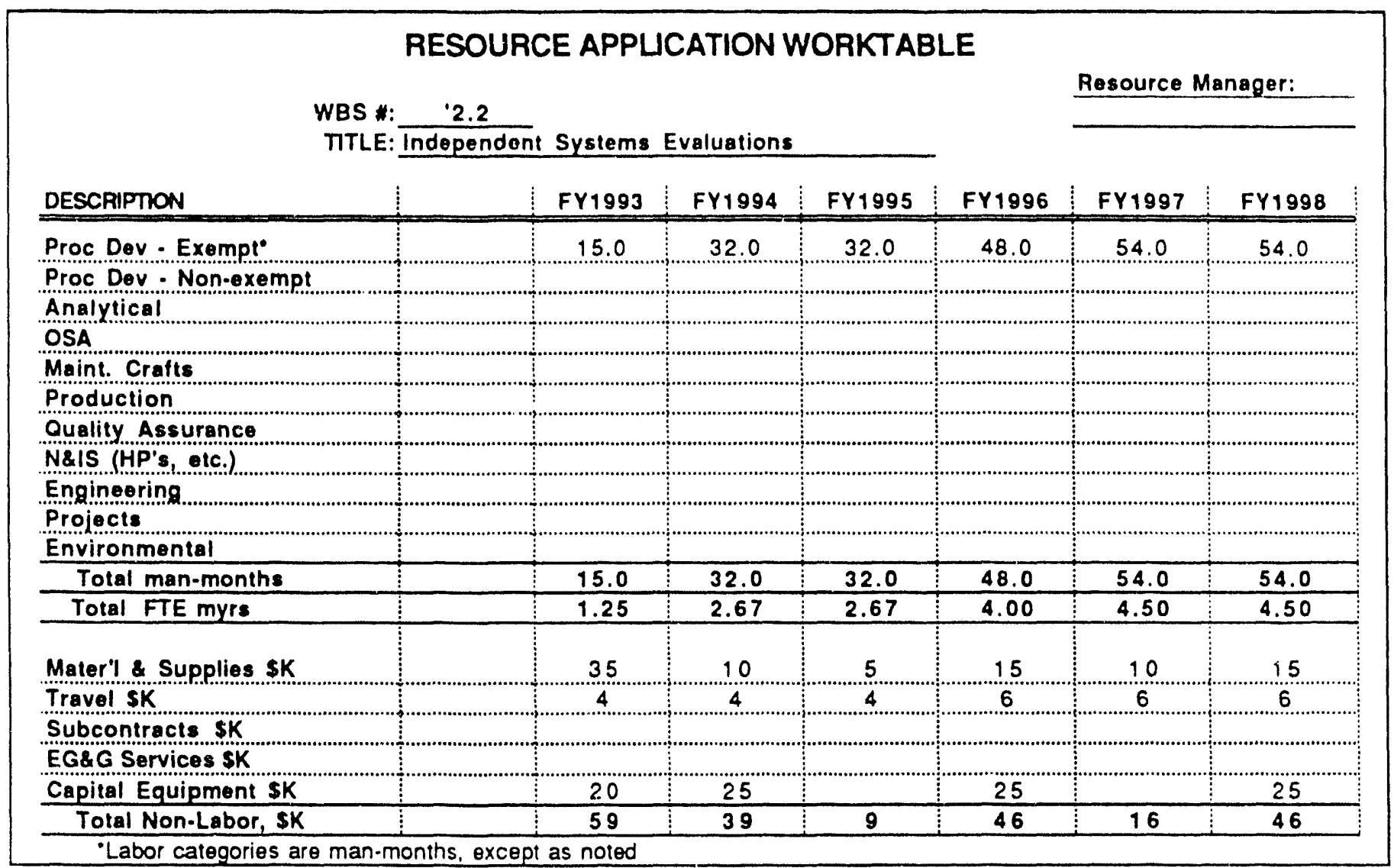




\section{RESOURCE APPUCATION WORKTABLE}

WBS *: $\quad 3.0$

Resource Manager:

TITLE: Direct Disposal of Spent Fuel

\begin{tabular}{|c|c|c|c|c|c|c|}
\hline DESCRIPION & FY1993 & FY1994 & FY1995 & FY 1996 & FY1997 & FY1998 \\
\hline Proc Dev - Exempt' & 45.0 & 147.0 & 180.0 & 132.0 & 116.0 & 108.0 \\
\hline Proc Dev - Non-exempt & 4.0 & 24.0 & 30.0 & 24.0 & 18.0 & 18.0 \\
\hline Analytical & 0.5 & 1.5 & 2.0 & 1.5 & 1.0 & 1.0 \\
\hline OSA & 3.5 & 3.0 & 3.5 & 2.5 & 2.5 & 2.0 \\
\hline Maint. Crafts & 0.5 & 6.5 & 8.5 & 7.0 & 6.0 & 6.0 \\
\hline \multicolumn{7}{|l|}{ Production } \\
\hline Quality Assurance & & 1.0 & 1.0 & 1.0 & 1.0 & 1.0 \\
\hline Nols (HP's etc.) & 0.5 & 1.5 & 2.0 & 1.5 & 1.0 & 1.0 \\
\hline 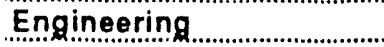 & & 6.0 & 8.0 & 6.0 & 6.0 & 6.0 \\
\hline \multicolumn{7}{|l|}{ Projects } \\
\hline Environmental & 3.0 & 2.5 & 2.0 & 1.5 & 1.5 & 1.0 \\
\hline Total man-months & 57.0 & 193.0 & 237.0 & 177.0 & 153.0 & 144.0 \\
\hline Total FTE myrs & 4.8 & 16.1 & 19.8 & 14.8 & 12.8 & 12.0 \\
\hline Mater'l \& Supplies SK & 44 & 69 & 77 & 52 & 42 & 30.0 \\
\hline Travel \$K & 12 & 22 & 24 & 16 & 14 & 12.0 \\
\hline Subcontracts \$K & 80 & 275 & 400 & 300 & 250 & 250.0 \\
\hline EGEG Services \$K & 40 & 30 & 40 & & & \\
\hline Capital Equipment SK & 175 & 265 & 370 & 250 & 225 & 225.0 \\
\hline Total Non-Labor, SK & 351 & 661 & 911 & 618 & 531 & 517 \\
\hline
\end{tabular}

\section{RESOURCE APPLCATION WORKTABLE}

WBS \#: $\quad 3.1$

Resource Manager:

TITLE: Identify Direct Disposal Criteria

\begin{tabular}{|c|c|c|c|c|c|c|}
\hline DESCRIPTION & FY1993 & FY1994 & FY 1995 & FY 1996 & FY1997 & FY1998 \\
\hline Pros: Dev - Exempt & 9.0 & 5.0 & 8.0 & 8.0 & 8.0 & \\
\hline \multicolumn{7}{|l|}{ Proc Dev - Non-exempt } \\
\hline \multicolumn{7}{|l|}{ Analytical } \\
\hline OSA & 1.0 & 0.5 & 0.5 & 0.5 & 0.5 & \\
\hline \multicolumn{7}{|l|}{ Maint. Crafts } \\
\hline \multicolumn{7}{|l|}{ Production } \\
\hline \multicolumn{7}{|l|}{ Quality Assurance } \\
\hline \multicolumn{7}{|l|}{ N\&IS (HP's, etc.) } \\
\hline \multicolumn{7}{|l|}{ Engineering } \\
\hline \multicolumn{7}{|l|}{ Projects } \\
\hline Environmental & 1.0 & 0.5 & 0.5 & 0.5 & 0.5 & \\
\hline Total man-months & 11.0 & 6.0 & 9.0 & 9.0 & 9.0 & \\
\hline Total FTE myrs & 0.9 & 0.5 & 0.8 & 0.8 & 0.8 & \\
\hline Mater'l \& Supplies \$K & 2 & 2 & 2 & $2 .$. & 2 & \\
\hline Travel \$K & 4. & 2 & 2 & 2 & 2 & \\
\hline \multicolumn{7}{|l|}{ Subcontracts \$K } \\
\hline \multicolumn{7}{|l|}{ EG\&G Services \$K } \\
\hline \multicolumn{7}{|l|}{ Capital Equipment SK } \\
\hline Total Non-Labor, SK & 6 & 4 & 4 & 4 & 4 & \\
\hline
\end{tabular}




\section{RESOURCE APPLICATION WORKTABLE}

Resource Manager:

WBS : $\quad 3.2$

TTLE: Identify Areas of Potential Concern

\begin{tabular}{|c|c|c|c|c|c|c|}
\hline DESCRIPION & FY1993 & FY1994 & FY 1995 & FY1996 & FY1997 & FY 1998 \\
\hline Proc Dev = Exempt" & 9.0 & 6.0 & & & & \\
\hline \multicolumn{7}{|l|}{ Proc Dev Non-exemp! } \\
\hline \multicolumn{7}{|l|}{ Analytical } \\
\hline OSA & 1.0 & 0.5 & & & & \\
\hline \multicolumn{7}{|l|}{ Maint. Crafts } \\
\hline \multicolumn{7}{|l|}{ Production } \\
\hline \multicolumn{7}{|l|}{ Quality Assurance } \\
\hline \multicolumn{7}{|l|}{ N\&IS (HP's etc.) } \\
\hline \multicolumn{7}{|l|}{ Engineering } \\
\hline \multicolumn{7}{|l|}{ Projects } \\
\hline Environmental & 1.0 & 0.5 & & & & \\
\hline Total man-months & 11.0 & 7.0 & & & & \\
\hline Total FTE myrs & 0.9 & 0.6 & & & & \\
\hline Mater'1 \& Supplies SK & 2. & 2 & & & & \\
\hline Travel SK & & 2 & & & & \\
\hline \multicolumn{7}{|l|}{ Subcontracts sk } \\
\hline \multicolumn{7}{|l|}{ EG\&G Services SK } \\
\hline \multicolumn{7}{|l|}{ Capital Equipment SK } \\
\hline Total Non-Labor, SK & 2 & 4 & & & & \\
\hline
\end{tabular}

- Labor categories are man-months, except as noted

\section{RESOURCE APPLICATION WORKTABLE}

WBS *: $\quad 3.3$

Resource Manager:

TITLE: Evaluate Packaging Alternatives

\begin{tabular}{|c|c|c|c|c|c|c|}
\hline DESCRIPTION & FY1993 & FY1994 & FY1995 & FY1996 & FY1997 & FY1998 \\
\hline Proc Dev = Exempt" & 18.0 & 28.0 & 28.0 & & & \\
\hline Proc Dev - Non-exempt & 3.0 & 6.0 & 6.0 & & & \\
\hline Analytica! & 0.5 & 0.5 & 0.5 & & & \\
\hline OSA & 1.0 & & & & & \\
\hline Maint. Crafts & 0.5 & 0.5 & 0.5 & & & \\
\hline \multicolumn{7}{|l|}{ Production } \\
\hline \multicolumn{7}{|l|}{ Quality Assurance } \\
\hline N\&IS (HP's, etc.) & 0.5 & 0.5 & 0.5 & & & \\
\hline \multicolumn{7}{|l|}{ 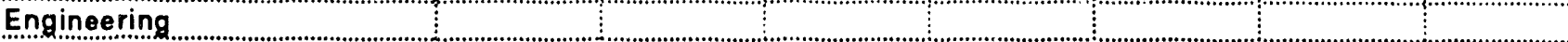 } \\
\hline \multicolumn{7}{|l|}{ Projects } \\
\hline Environmental & 0.5 & 0.5 & 0.5 & & & \\
\hline Total man-montris & 24.0 & 36.0 & 36.0 & & & \\
\hline Total FTE myrs & 2.0 & 3.0 & 3.0 & & & \\
\hline Mater'l \& Supplies SK & 20 & 20 & 15 & & & \\
\hline Travel \$K & 6 & 6 & 6 & & & \\
\hline Subcontracts sk & 80 & 75 & 50 & & & \\
\hline \multicolumn{7}{|l|}{ EG\& G Services SK } \\
\hline Capital Equipment sk & 35 & 40 & 70 & & & \\
\hline Total Non-Labor, SK & 141 & 141 & 141 & & & \\
\hline
\end{tabular}




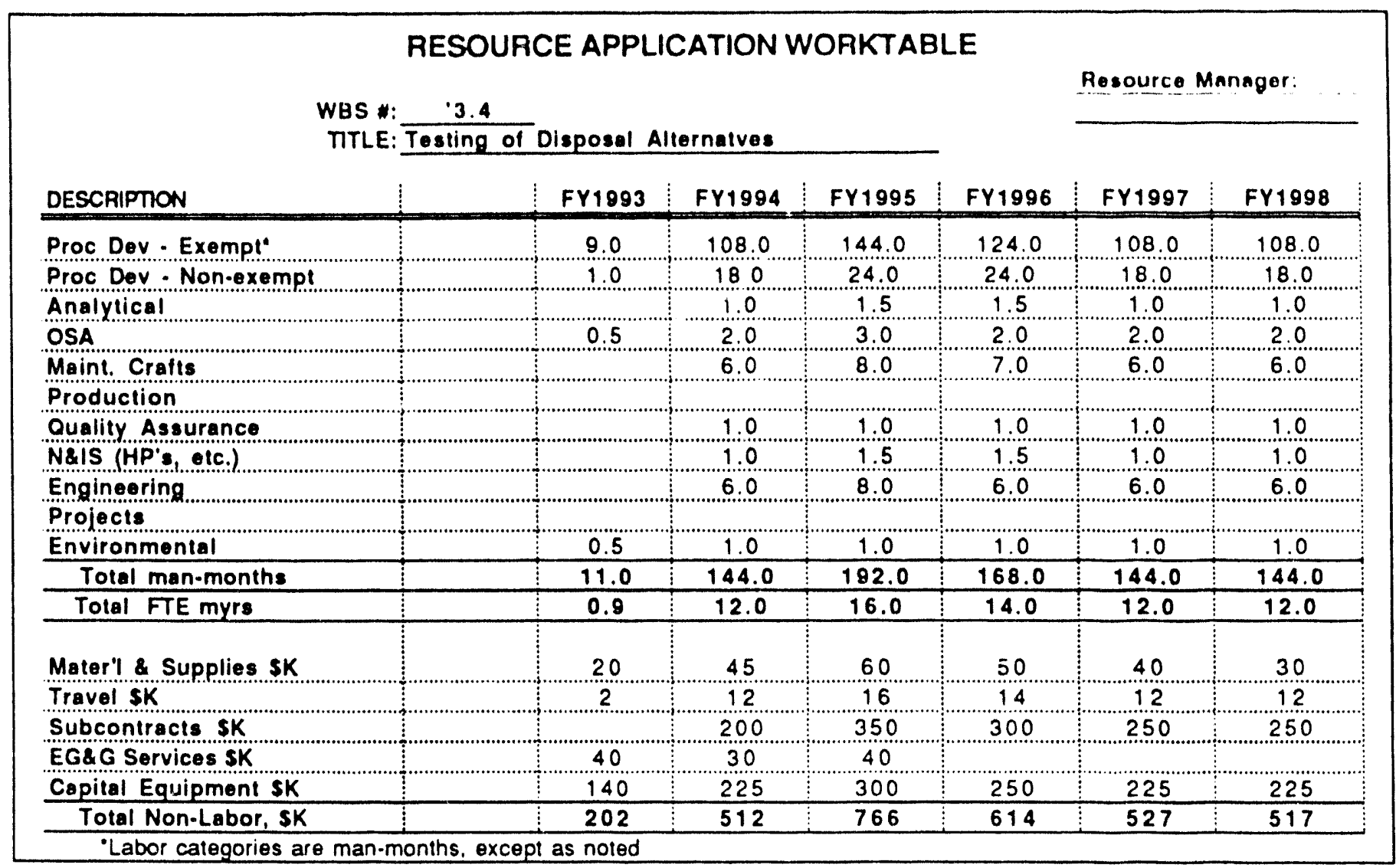




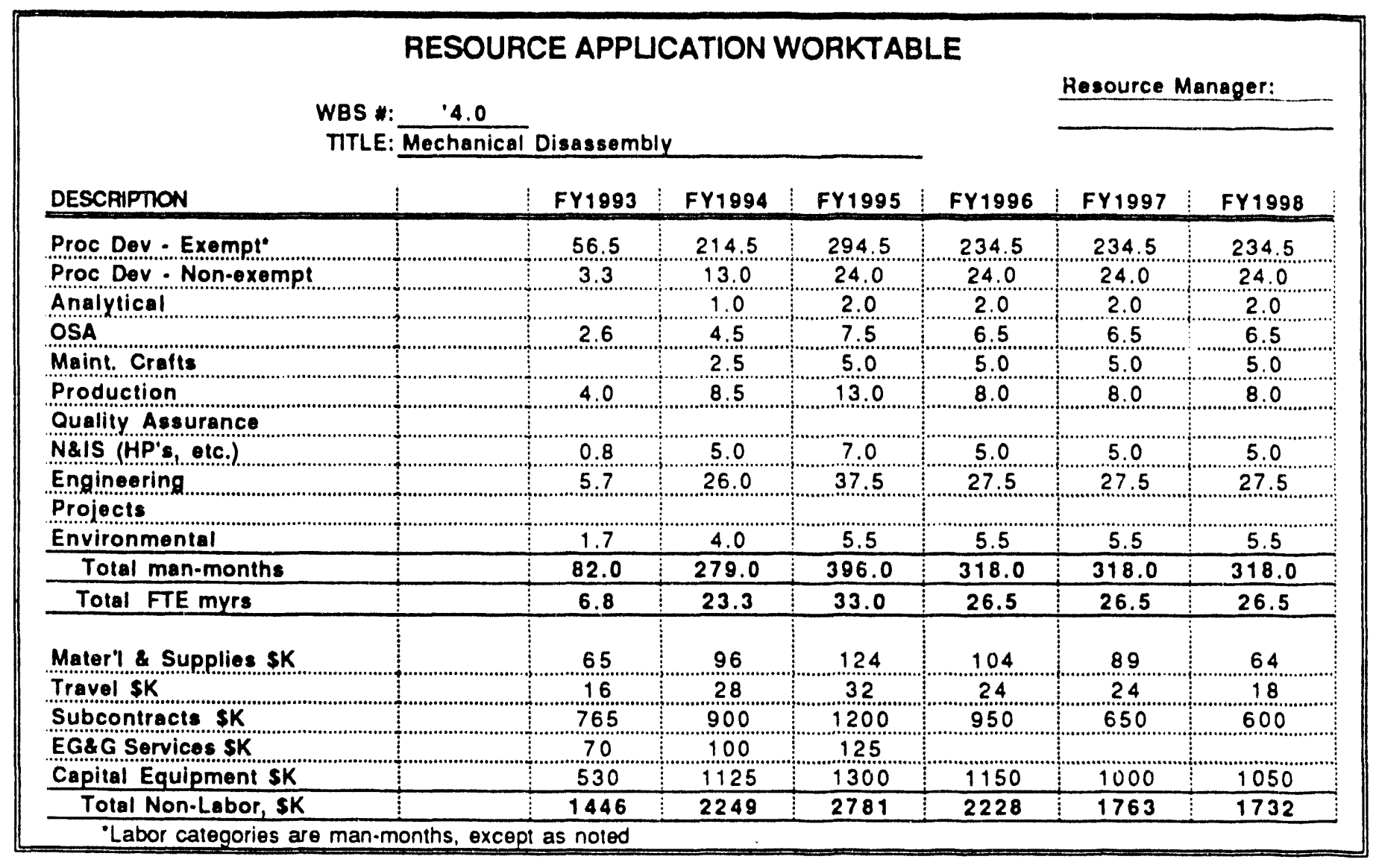

\section{RESOURCE APPLICATION WORKTABLE}

WBS *: $\quad 4.1$

Resource Manager:

TITLE: FSV Fuel Rod/Block Separation

\begin{tabular}{|c|c|c|c|c|c|c|}
\hline DESCRIPTION & FY1993 & FY1994 & FY1995 & FY1996 & FY1997 & FY1998 \\
\hline Proc Dev - Exempt' & 24.0 & 118.0 & 155.0 & 118.0 & 118.0 & 118.0 \\
\hline Proc Dev - Non-exempt & 2.0 & 3.0 & 4.0 & 4.0 & 4.0 & 4.0 \\
\hline \multicolumn{7}{|l|}{ Analytica! } \\
\hline OSA & 1.0 & 2.0 & 3.0 & 2.0 & 2.0 & 2.0 \\
\hline \multicolumn{7}{|l|}{ Maint Cratts } \\
\hline Production & 2.0 & 5.0 & 8.0 & 5.0 & 5.0 & 5.0 \\
\hline \multicolumn{7}{|l|}{ Quality Assurance } \\
\hline N\&IS (HP's, etc.) & 0.5 & 3.0 & 3.0 & 2.0 & 2.0 & 2.0 \\
\hline Engineering & 9.0 & 12.0 & 18.0 & 12.0 & 12.0 & 12.0 \\
\hline \multicolumn{7}{|l|}{ Projects } \\
\hline Environmental & 0.5 & 1.0 & 1.0 & 1.0 & 1.0 & 1.0 \\
\hline Total man-months & 39.0 & 144.0 & 192.0 & 144.0 & 144.0 & 144.0 \\
\hline Total FTE myrs & 3.25 & 12.00 & 16.00 & 12.00 & 12.00 & 12.00 \\
\hline Mater'l \& Supplies \$K & 35 & 50 & 60 & 50 & 40 & 30 \\
\hline Travel \$K & 10 & 12 & 16 & 12 & 12 & 12 \\
\hline Subcontracts $\$ K$ & 765 & 750 & 1000 & 750 & 500 & 500 \\
\hline EG\& G Services \$K & 60 & 75 & 100 & & & \\
\hline Capital Equipment sk & 340 & 700 & 700 & 500 & 500 & 500 \\
\hline Tolal Non-Labor, SK & 1210 & 1587 & 1876 & 1312 & 1052 & 1042 \\
\hline
\end{tabular}


RESOURCE APPLICATION WORKTABLE

WBS : $\quad \cdot 4.2$

Resource Manager:

TTLE: Non-FSV Fuel Disassembly

\begin{tabular}{|c|c|c|c|c|c|c|}
\hline DESCRIPION & FY1993 & FY1994 & FY1995 & FY1996 & FY1997 & FY 1998 \\
\hline Proc Dev Exempt & 19.0 & 69.0 & 92.0 & 69.0 & 69.0 & 69.0 \\
\hline Proc Dev Non-exempt & 2.0 & 3.0 & 3.0 & 3.0 & 3.0 & 3.0 \\
\hline \multicolumn{7}{|l|}{ Analytical } \\
\hline OSA & 1.0 & 1.0 & 1.0 & 1.0 & 1.0 & 1.0 \\
\hline \multicolumn{7}{|l|}{ Maint Crafts } \\
\hline Production & 1.0 & 3.0 & 5.0 & 3.0 & 3.0 & 3.0 \\
\hline \multicolumn{7}{|l|}{ Ouality Assurance } \\
\hline Neis (HP's etc.) & 0.5 & 1.0 & 2.0 & 1.0 & 1.0 & 1.0 \\
\hline Engineering & 3.0 & 12.0 & 16.0 & 12.0 & 12.0 & 12.0 \\
\hline \multicolumn{7}{|l|}{ Projects } \\
\hline Environmental & 0.5 & 1.0 & 1.0 & 1.0 & 1.0 & 1.0 \\
\hline Total man-months & 27.0 & 90.0 & 120.0 & 90.0 & 90.0 & 90.0 \\
\hline Total FTE myrs & 2.25 & 7.50 & 10.00 & 7.50 & 7.50 & 7.50 \\
\hline Mater' \& Supplies SK & 20 & 30 & 40 & 30 & 25 & 20 \\
\hline Travel sk & 6 & 12 & 12 & 12 & 12 & 6 \\
\hline Subcontracts sK & & 150 & 200 & 200 & 150 & 100 \\
\hline EG\&G Services SK & 10 & 25 & 25 & & & \\
\hline Capital Equipment SK & 150 & 250 & 300 & 300 & 200 & 200 \\
\hline Tolal Non-Labor, SK & 186 & 467 & 577 & 542 & 387 & 326 \\
\hline
\end{tabular}

\section{RESOURCE APPUCATION WORKTABLE}

WBS : 4.3

Resource Manager:

TITLE: LLW Assembly Scrap Disposal

\begin{tabular}{|c|c|c|c|c|c|c|}
\hline DESCRIPTION & FY1993 & FY1994 & FY 1995 & FY1996 & FY1997 & FY1998 \\
\hline Proc Dev - Exempt' & 6.0 & 16.5 & 28.0 & 28.0 & 28.0 & 28.0 \\
\hline Proc Dev - Non-exempt & & 4.0 & 9.0 & 9.0 & 9.0 & 9.0 \\
\hline Analytical & & 1.0 & 1.0 & 1............ & (1.0. & 1.0 \\
\hline OSA & 0.5 & 1.0 & 2.0 & 2.0 & 2.0 & 2.0 \\
\hline Maint Crafts & & 2.0 & 3.0 & 3.0 & (3.0 & 3.0 \\
\hline Production & 0.5 & & & & & \\
\hline \multicolumn{7}{|l|}{ Quality Assurance } \\
\hline N\&IS (HP's, etc.) & & 0.5 & 1.0 & 1.0 & 1.0 & 1.0 \\
\hline Engineering & 0.5 & 1........... & 2.............. & 2.0 & 2.0 & 2.0 \\
\hline \multicolumn{7}{|l|}{ Projects } \\
\hline Environmental & 0.5 & 1.0 & 2.0 & 2.0 & 2.0 & 2.0 \\
\hline Total man-months & 8.0 & 27.0 & 48.0 & 48.0 & 48.0 & 48.0 \\
\hline Total FrE myrs & 0.67 & 2.25 & 4.00 & 4.00 & 4.00 & 4.00 \\
\hline Moter'l \& Supplies SK & 5 & 8 & 12 & 12 & 12 & 8 \\
\hline Travel SK & & 2 & 2 & & & \\
\hline \multicolumn{7}{|l|}{ Subconiracts \$K } \\
\hline \multicolumn{7}{|l|}{ EG\&G Services \$K } \\
\hline Capital Equipment $\$ K$ & 25 & 100 & 150 & 150 & 150 & 150 \\
\hline Total Non-Labor, SK & 30 & 110 & 164 & 162 & 162 & 158 \\
\hline
\end{tabular}




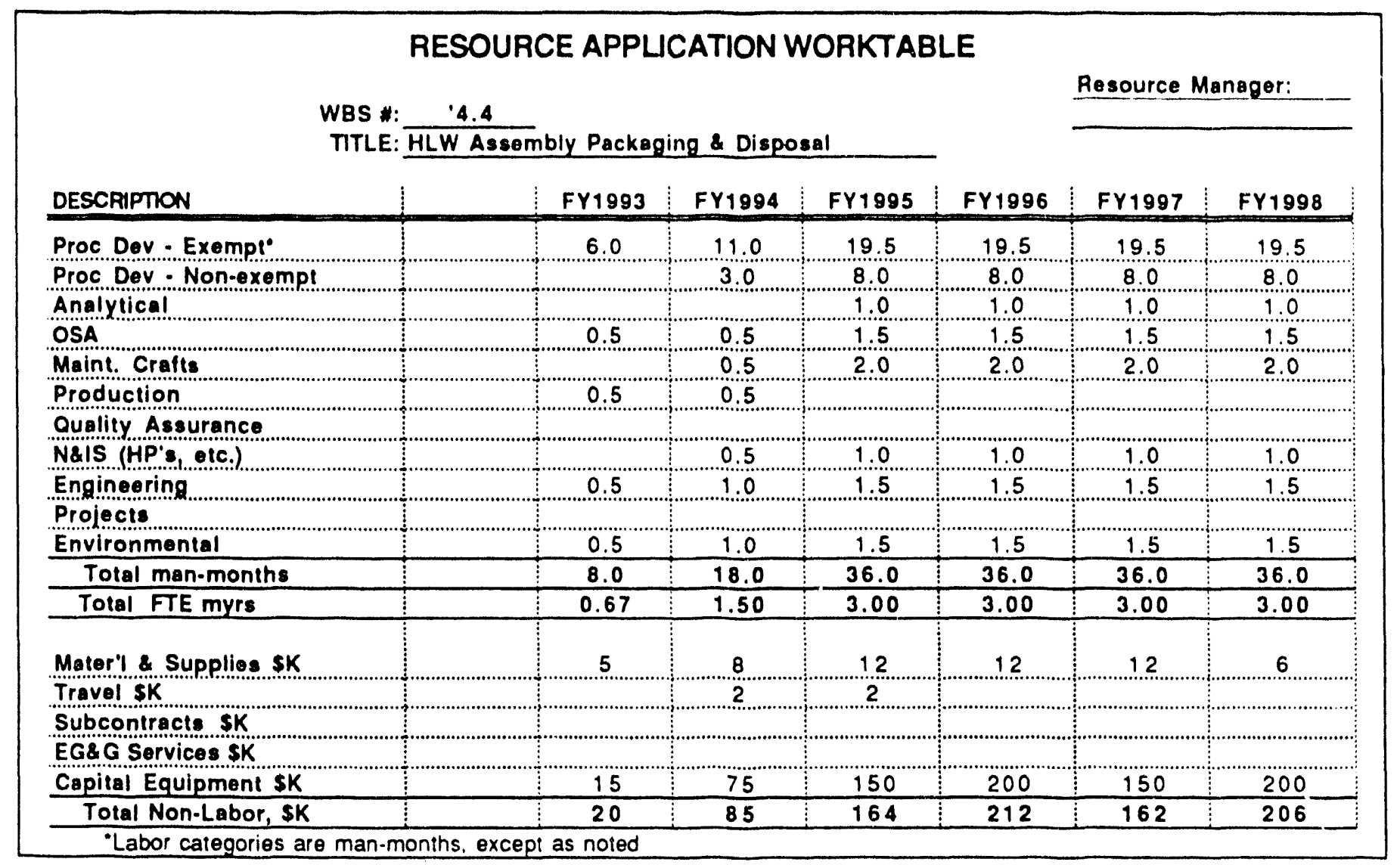




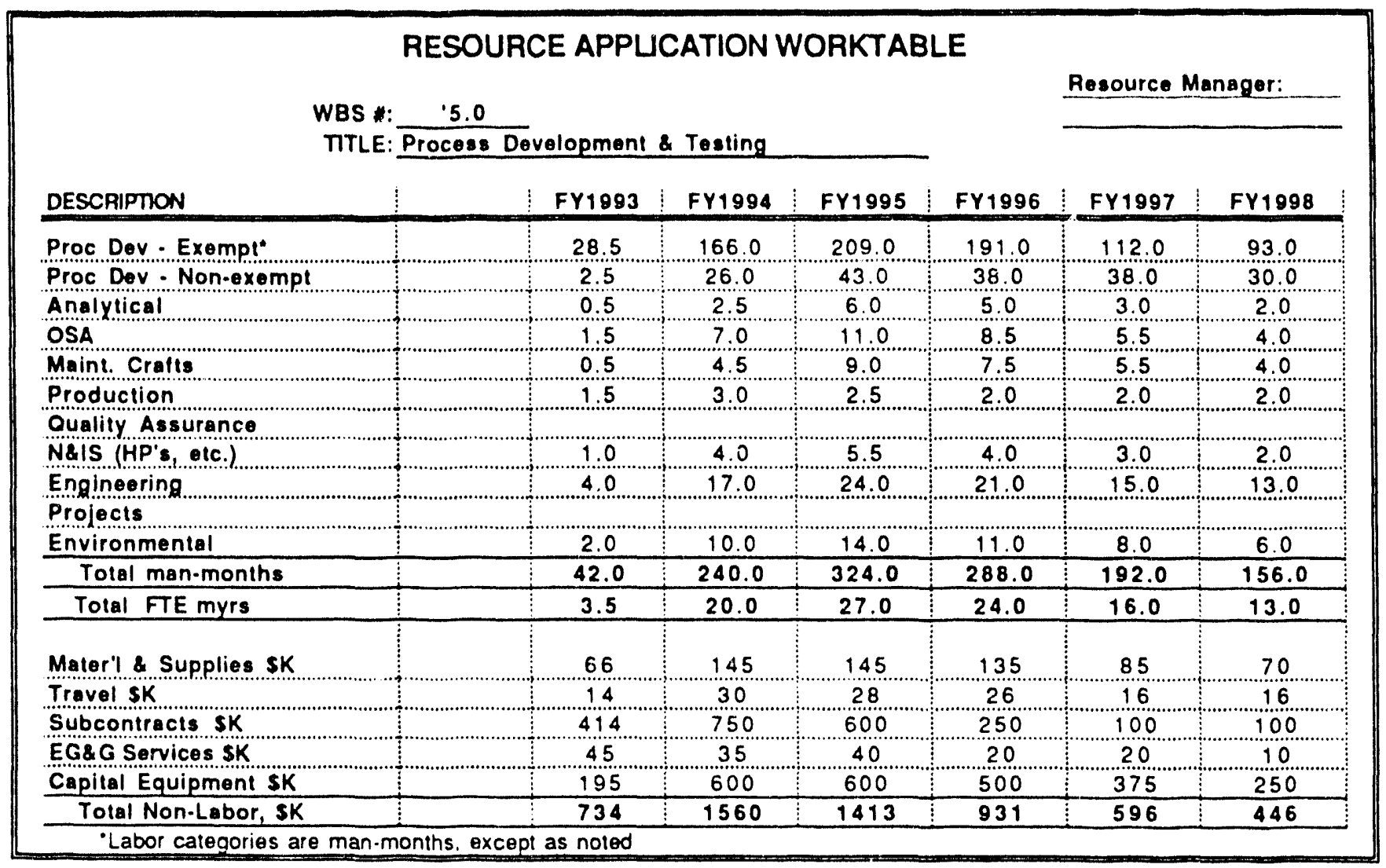

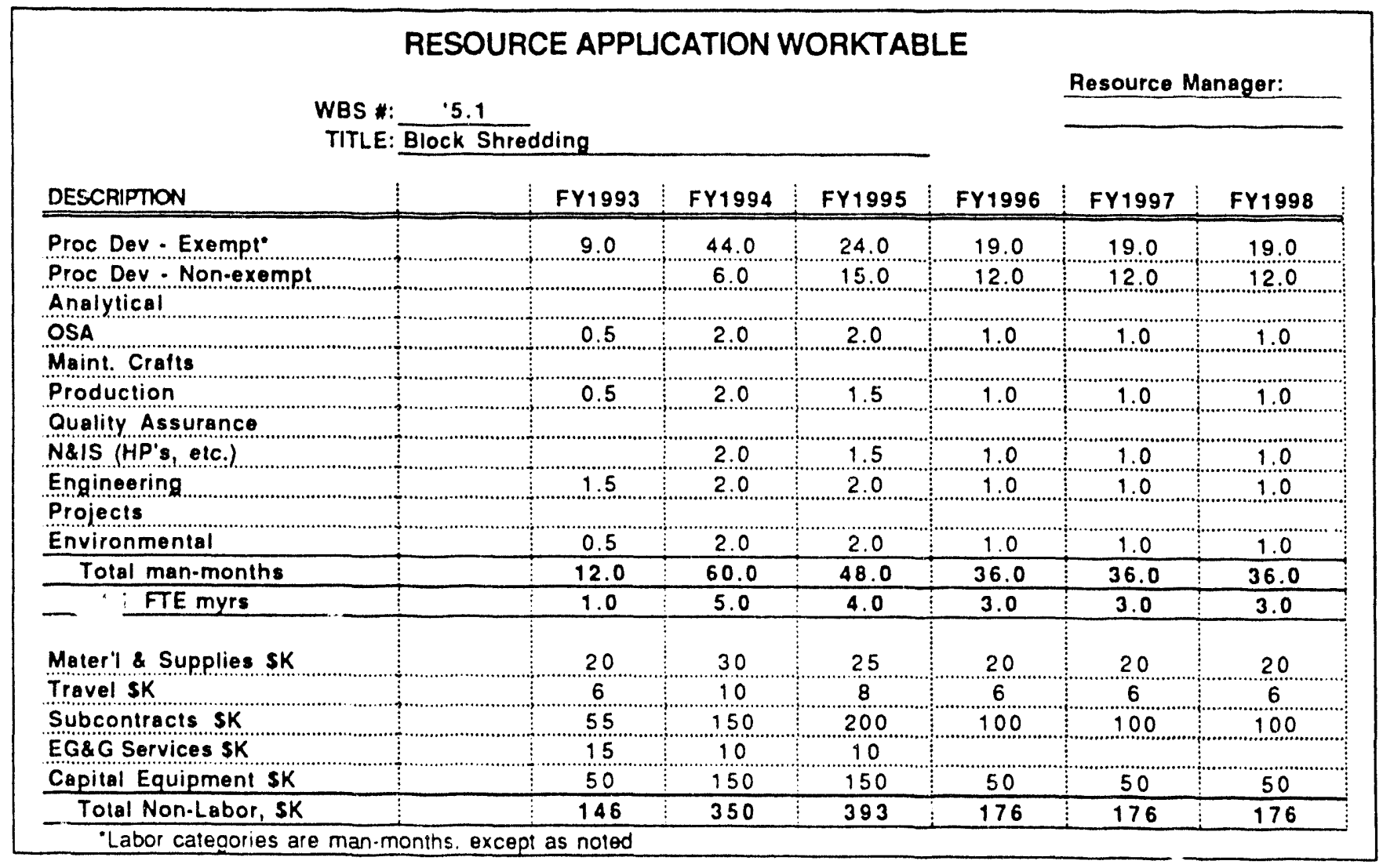


RESOURCE APPLCATION WORKTABLE

WBS *: $\quad 5.2$

Resource Manager:

TITLE: Bulk Graphite Burner and Ofi-Gas Cleanup

\begin{tabular}{|c|c|c|c|c|c|c|}
\hline DESCRIPTION & FY1993 & FY1994 & FY1995 & FY1996 & FY 1997 & FY1998 \\
\hline Proc Dev - Exempt" & 16.0 & 104.0 & 153.0 & 153.0 & 74.0 & 74.0 \\
\hline Proc Dev - Non-exempt & 2.0 & 12.0 & 18.0 & 18.0 & 18.0 & 18.0 \\
\hline Analytical & 0.5 & 2.0 & 4.0 & 4.0 & 2.0 & 2.0 \\
\hline OSA & 0.5 & 3.0 & 6.0 & 6.0 & 3.0 & 3.0 \\
\hline Maint. Crafts & 0.5 & 4.0 & 6.0 & 6.0 & 4.0 & 4.0 \\
\hline Production & 1.0 & 1.0 & 1.0 & 1.0 & 1.0 & 1.0 \\
\hline \multicolumn{7}{|l|}{ Quality Assurance } \\
\hline N\&IS (HP's, otc.) & 0.5 & 1.0 & 2.0 & 2.0 & 1.0 & 1.0 \\
\hline Engineering & 2.0 & 12.0 & 18.0 & 18.0 & 12.0 & 12.0 \\
\hline \multicolumn{7}{|l|}{ Projects } \\
\hline Environmental & 1.0 & 5.0 & 8.0 & 8.0 & 5.0 & 5.0 \\
\hline Total man-months & 24.0 & 144.0 & 216.0 & 216.0 & 120.0 & 120.0 \\
\hline Totsl FTE myrs & 2.0 & 12.0 & 18.0 & 18.0 & 10.0 & 10.0 \\
\hline Mater'l \& Supplies SK & 35 & 100 & 100 & 100 & 50 & 50 \\
\hline Travel \$K & 8 & 20 & 20 & 20 & 10 & 10 \\
\hline Subcontracts \$K & 359 & 600 & 400 & 150 & & \\
\hline EG\&G Services SK & 30 & 25 & 30 & 20 & 20 & 10 \\
\hline Capital Equipment SK & 145 & 400 & 400 & 400 & 300 & 200 \\
\hline Total Non-Labor, SK & 577 & 1145 & 950 & 690 & 380 & 270 \\
\hline
\end{tabular}

- Labor categories are man-months, except as noted

RESOURCE APPLICATION WORKTABLE

WBS : $\quad 5.3$

Resource Manager:

TITLE: Disposal of Burner Ash

\begin{tabular}{|c|c|c|c|c|c|c|}
\hline DESCRIPTION & FY1993 & FY1994 & FY1995 & FY1996 & FY1997 & FY1998 \\
\hline Proc Dev - Exempt* & 3.5 & 18.0 & 32.0 & 19.0 & 19.0 & \\
\hline Proc Dev - Non-exempt & 0.5 & 8.0 & 10.0 & 8.0 & 8.0 & \\
\hline Analytical & & 0.5 & 2.0 & 1.0 & 1.0 & \\
\hline OSA & 0.5 & 2.0 & 3.0 & 1.5 & 1.5 & \\
\hline Maint. Crafts & & 0.5 & 3.0 & 1.5 & 1.5 & \\
\hline \multicolumn{7}{|l|}{ Production } \\
\hline \multicolumn{7}{|l|}{ Ouality Assurance } \\
\hline Nois (HP's, etc.) & 0.5 & 1.0 & 2.0 & 1.0 & 1.0 & \\
\hline Engineering & 0.5 & 3.0 & 4.0 & 2.0 & 2.0 & \\
\hline \multicolumn{7}{|l|}{ Projects } \\
\hline Environmental & 0.5 & 3.0 & 4.0 & 2.0 & 2.0 & \\
\hline Total man-months & 6.0 & 36.0 & 60.0 & 36.0 & 36.0 & \\
\hline Total FTE myrs & 0.5 & 3.0 & 5.0 & 3.0 & 3.0 & \\
\hline Mater'l \& Supplies \$K & 11 & 15 & 20 & 15 & 15 & \\
\hline \multicolumn{7}{|l|}{ Trevel \$K } \\
\hline \multicolumn{7}{|l|}{ Subcontracts SK } \\
\hline \multicolumn{7}{|l|}{ EG\& G Services SK } \\
\hline Capital Equipmesil SK & & 50 & 50 & 50 & 25 & \\
\hline Total Non-Labor, SK & 11 & 65 & 70 & 65 & 40 & \\
\hline
\end{tabular}




\section{RESOURCE APPUCATION WORKTABLE}

WBS *: $\quad 6.0$

Resource Manager:

TITLE: Spent Graphito Fuels Examination

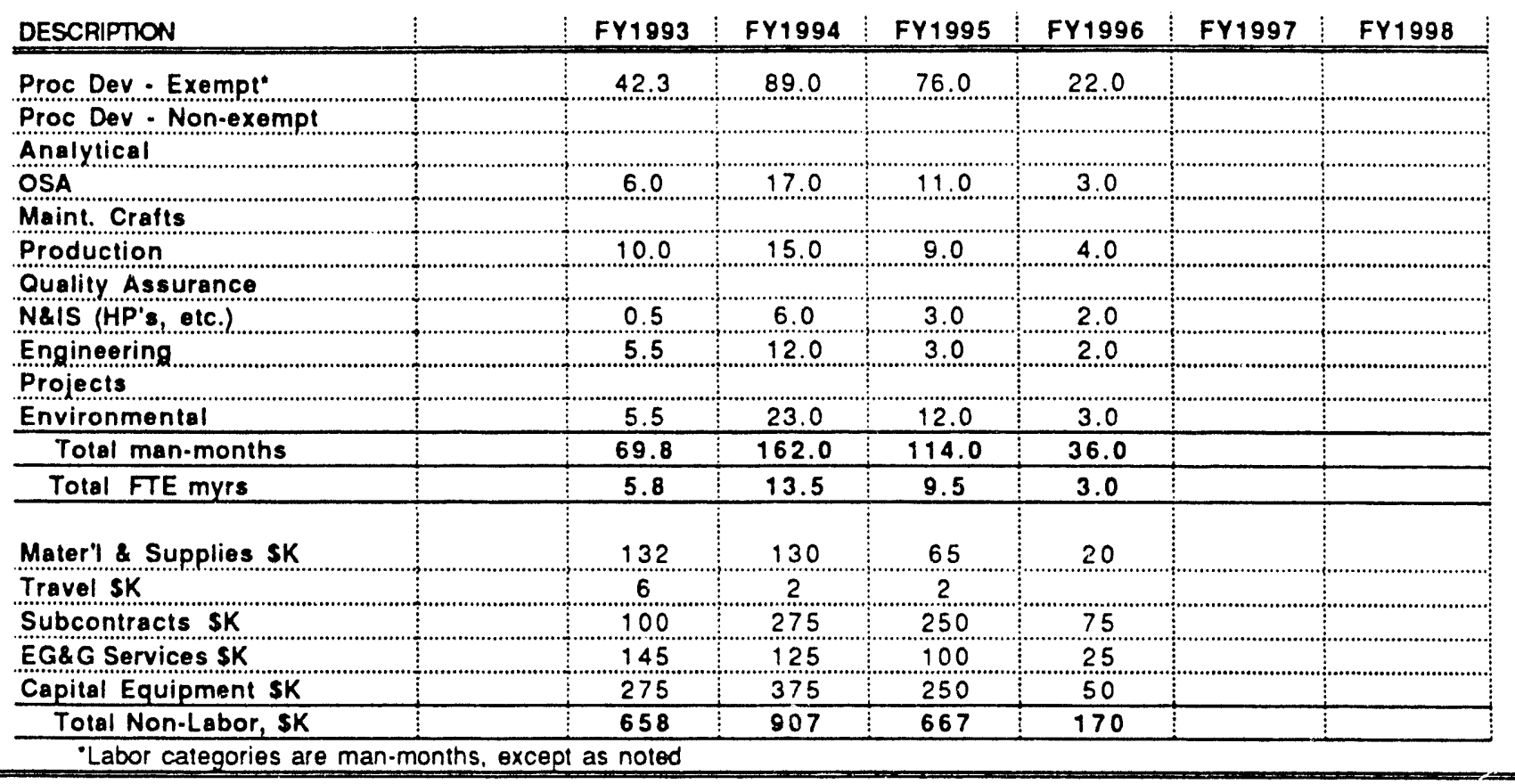

\section{RESOURCE APPLCATION WORKTABLE}

WBS $: \quad \cdot 6.1$

Resource Manager:

TITLE: Scope of Inspection

\begin{tabular}{|c|c|c|c|c|c|c|}
\hline DESCRIPTION & FY1993 & FY1994 & FY1995 & FY1996 & FY1997 & FY 1998 \\
\hline Proc Dev - Exempt & 7.8 & & & & & \\
\hline \multicolumn{7}{|l|}{ Proc Dev - Nonexempt } \\
\hline \multicolumn{7}{|l|}{ Analytical } \\
\hline \multicolumn{7}{|l|}{ OSA } \\
\hline \multicolumn{7}{|l|}{ Maint. Crafts } \\
\hline Production & 1.0 & & & & & \\
\hline \multicolumn{7}{|l|}{ Quality Assurance } \\
\hline \multicolumn{7}{|l|}{ N\&IS (HP's, etc.) } \\
\hline \multicolumn{7}{|l|}{ Engineering } \\
\hline \multicolumn{7}{|l|}{ Projects } \\
\hline Environmental & 1.0 & & & & & \\
\hline Tolal man-months & 10.8 & & & & & \\
\hline Total FTE myrs & 0.9 & & & & & \\
\hline \multicolumn{7}{|l|}{ Mater'l \& Supplies SK } \\
\hline \multicolumn{7}{|l|}{ Travel \$K } \\
\hline \multicolumn{7}{|l|}{ Subcontracts sk } \\
\hline \multicolumn{7}{|l|}{ EG\&G Services SK } \\
\hline \multicolumn{7}{|l|}{ Capital Equipment SK } \\
\hline Total Non-Labor, SK & 7 & & & & & \\
\hline
\end{tabular}




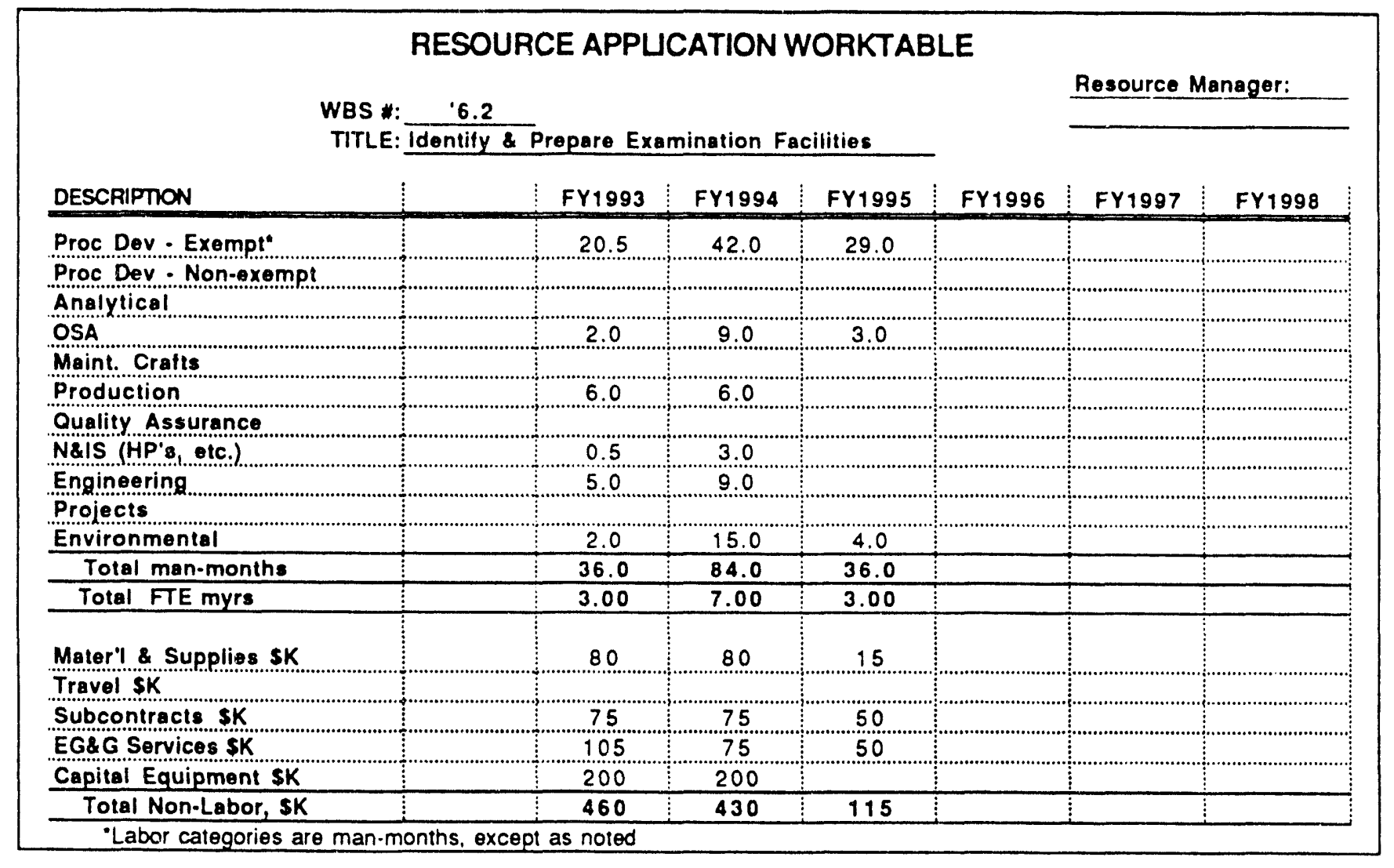

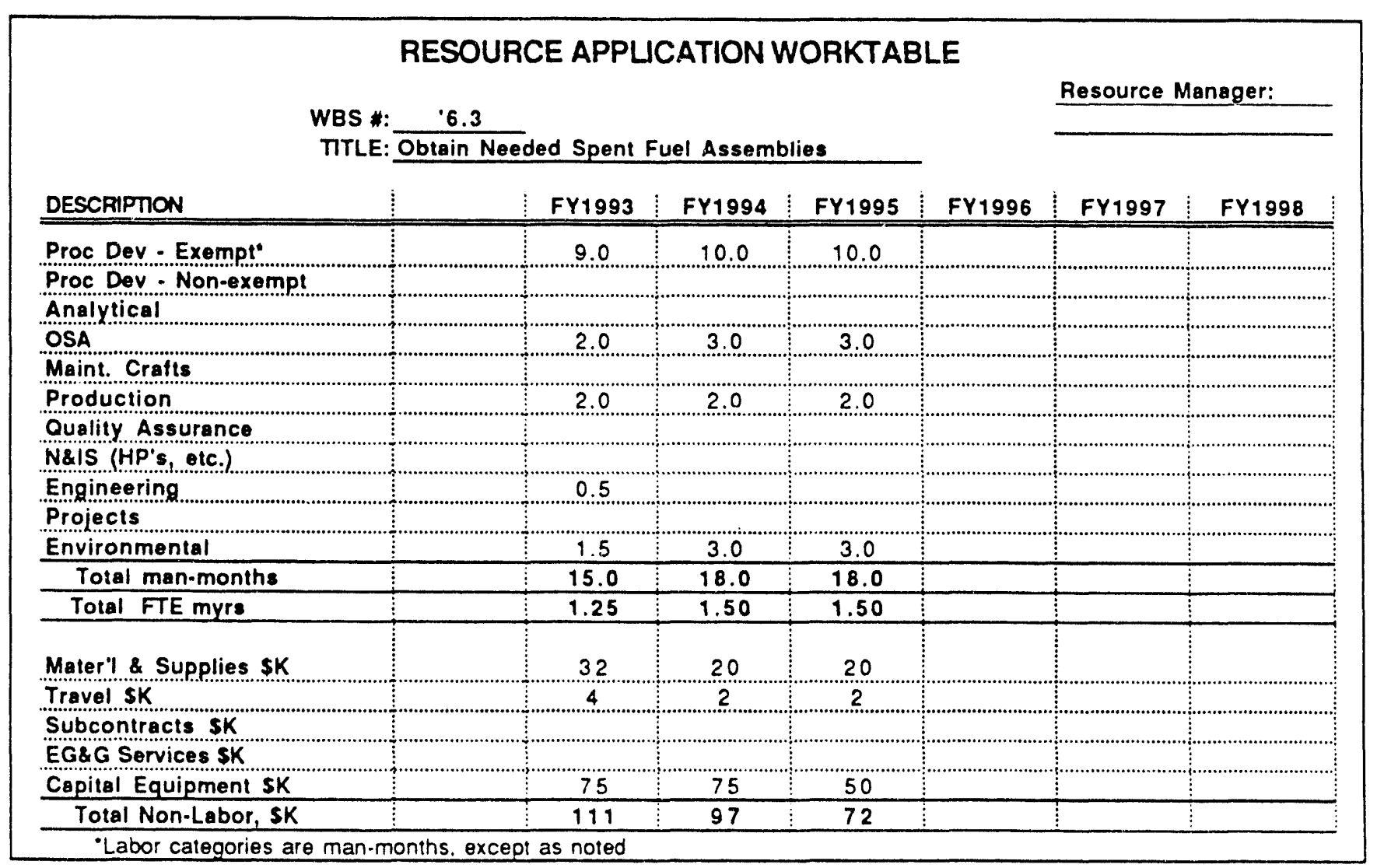




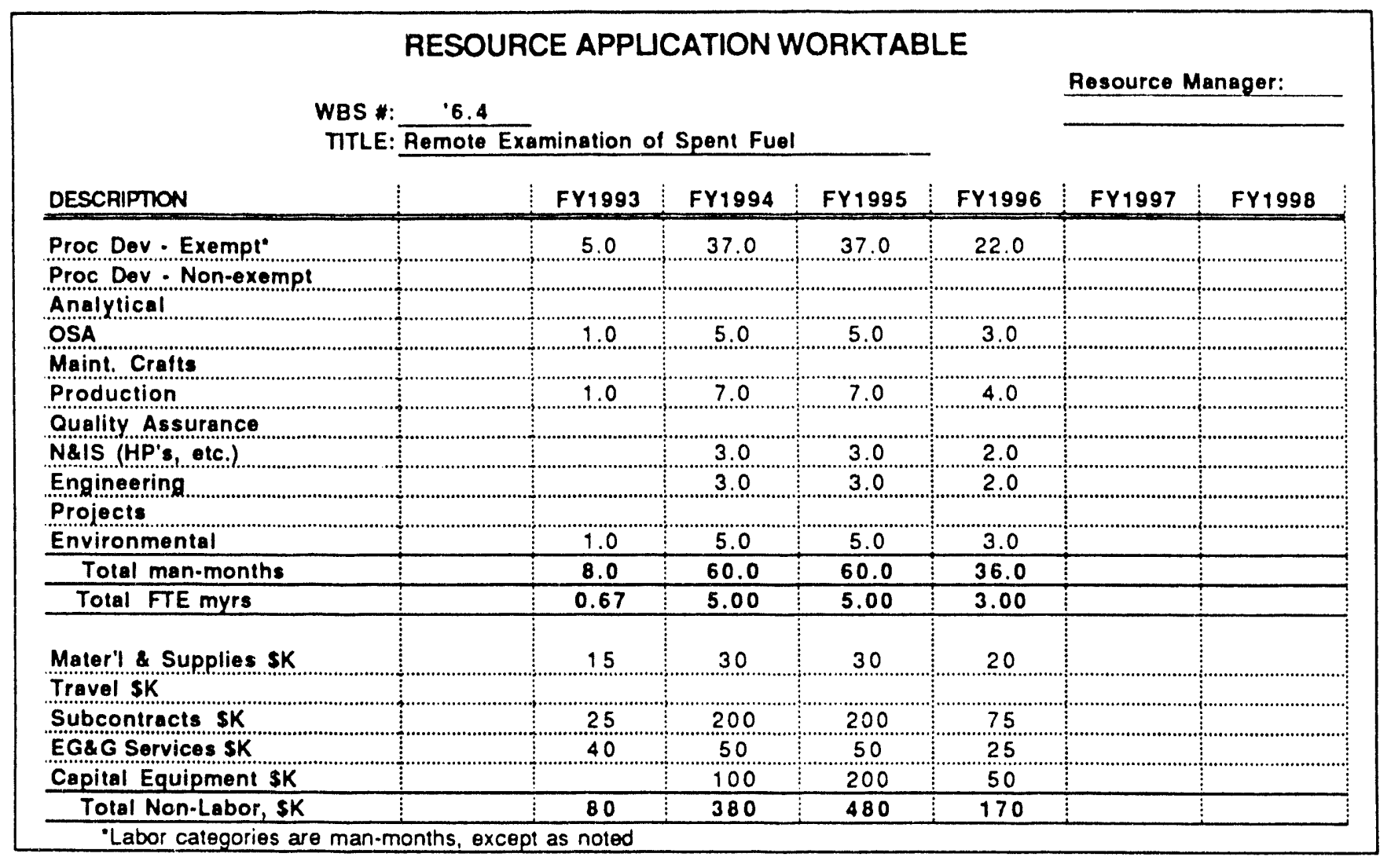




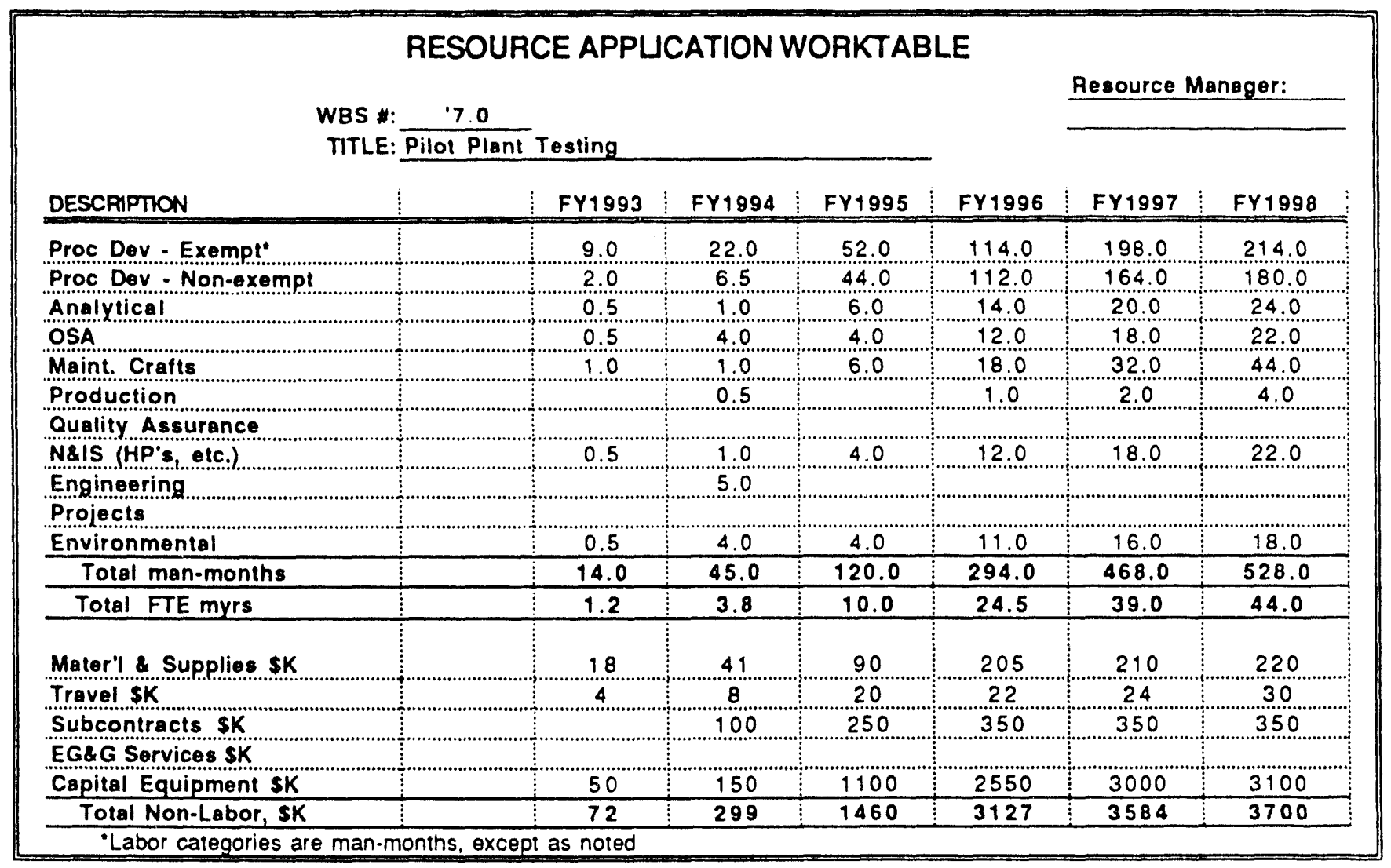

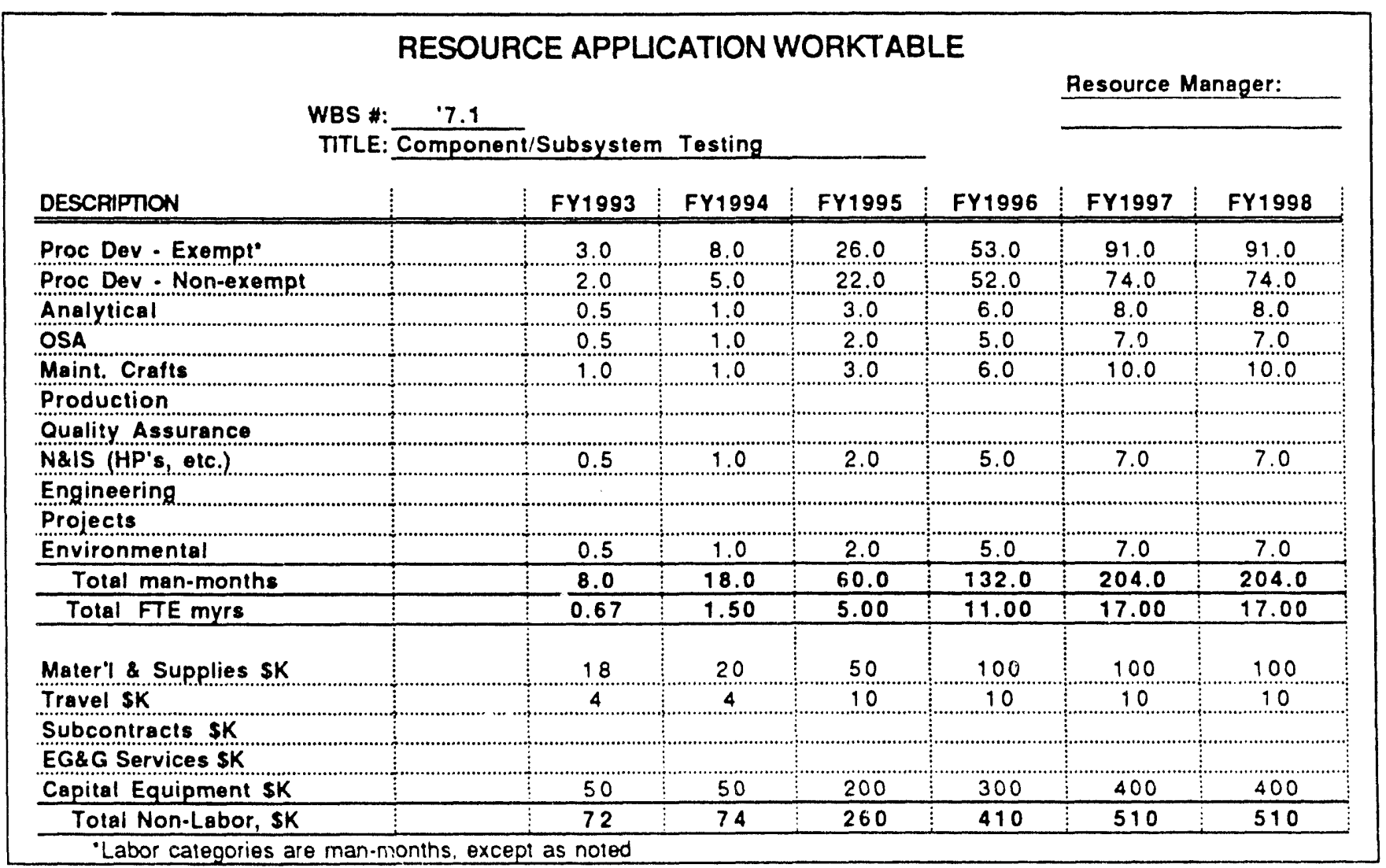




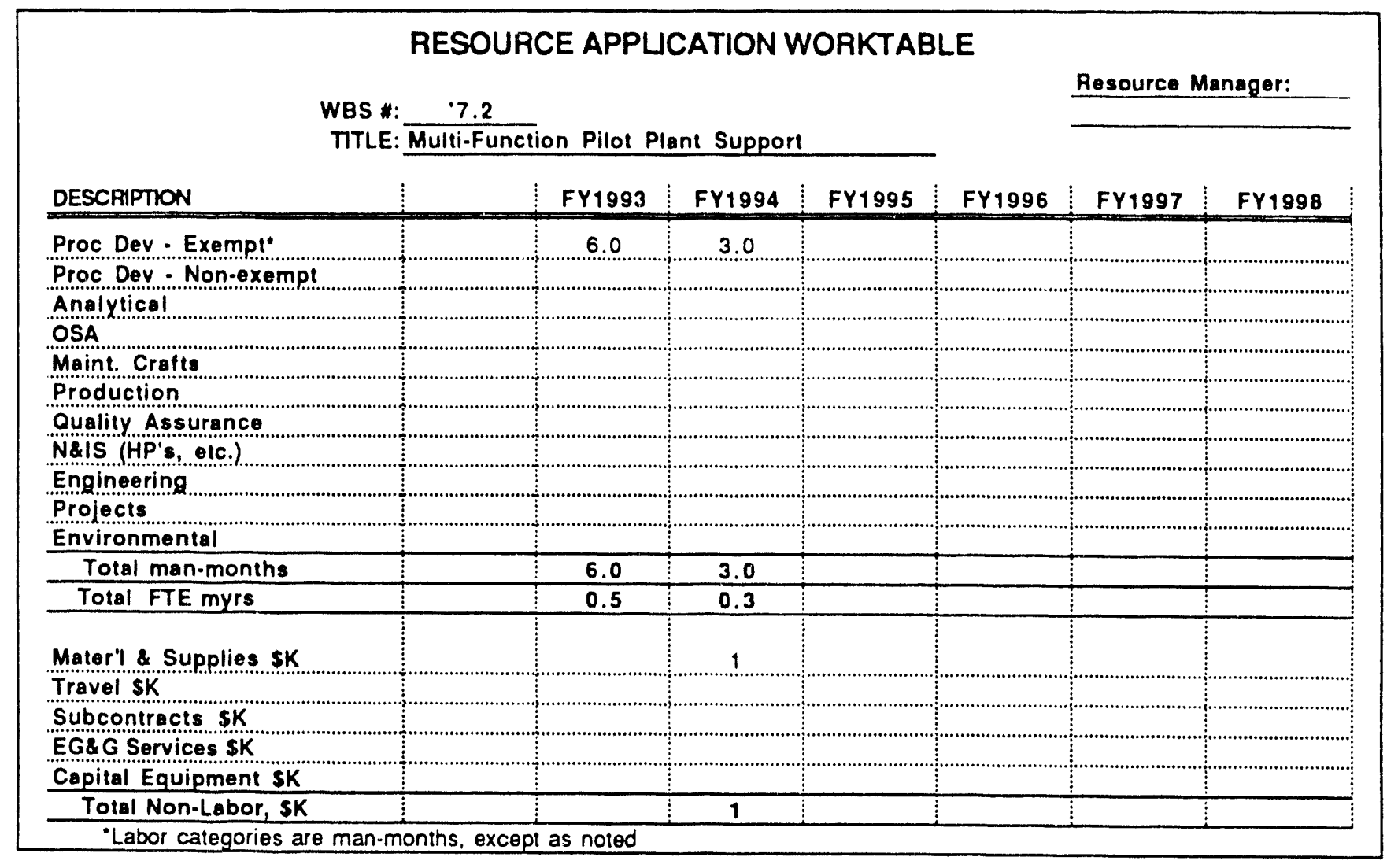

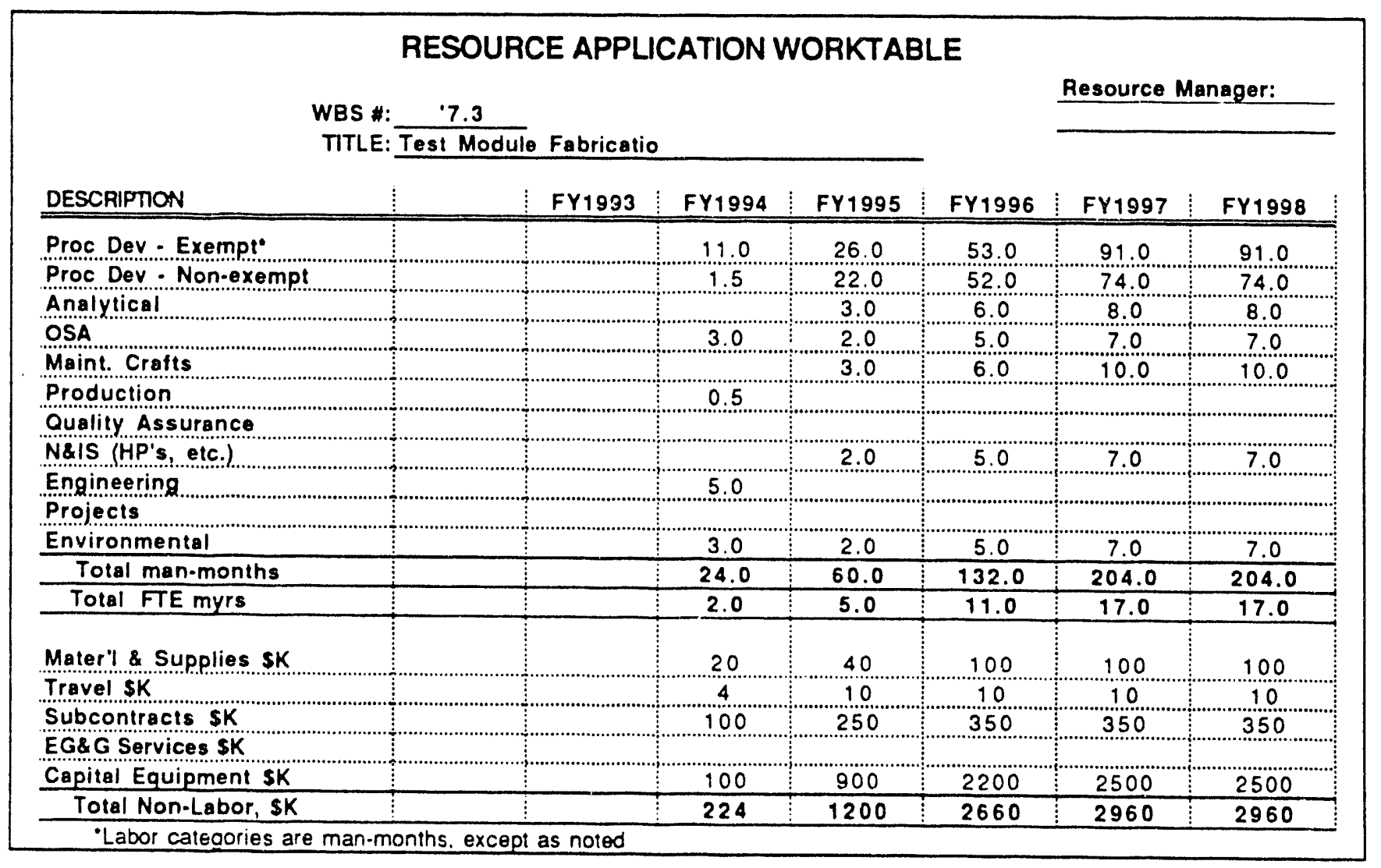




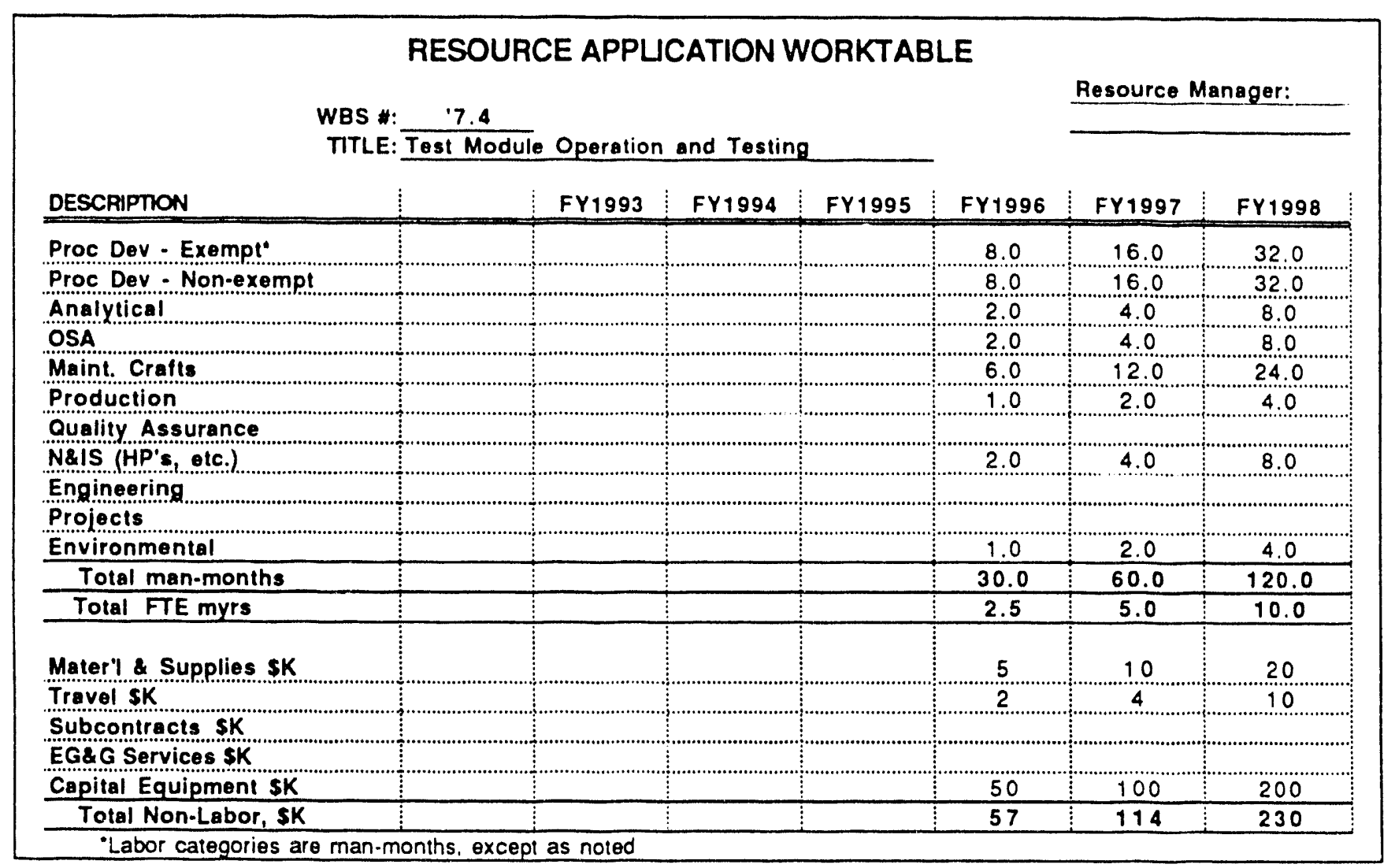




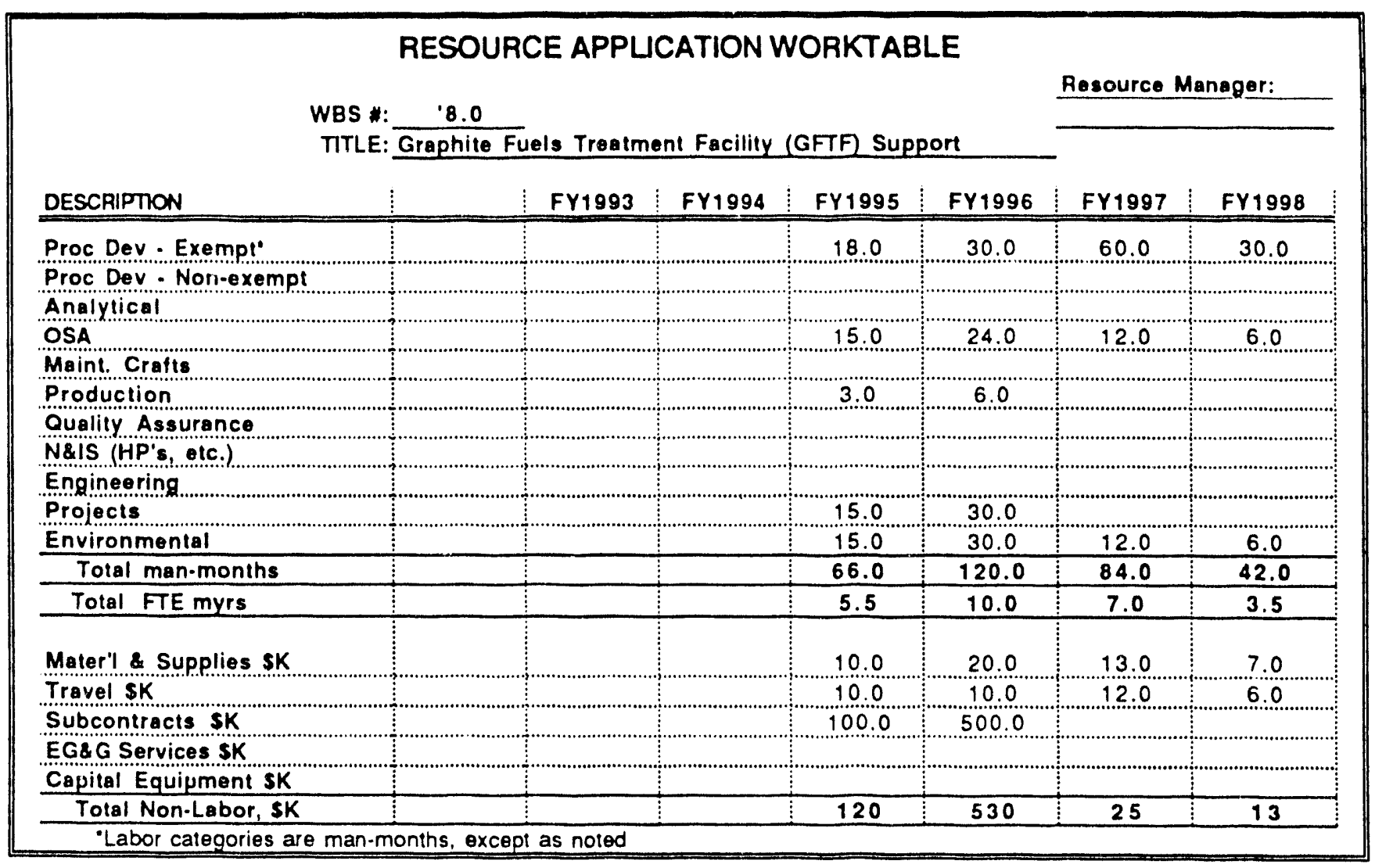

\section{RESOURCE APPUCATION WORKTABLE}

WBS \#: $\quad 8.1$

Resource Manager:

TITLE: Feasibility Siudies

\begin{tabular}{|c|c|c|c|c|c|c|}
\hline DESCRIPIION & FY1993 & FY1994 & FY1995 & FY1996 & FY1997 & FY 1998 \\
\hline Proc Dev - Exempt & & & 18.0 & 30.0 & 30.0 & \\
\hline \multicolumn{7}{|l|}{ Proc Dev - Non-exempt } \\
\hline \multicolumn{7}{|l|}{ Analytical } \\
\hline OSA & & & 15.0 & 24.0 & 6.0 & \\
\hline \multicolumn{7}{|l|}{ Maint. Crafts } \\
\hline Production & & & 3.0 & 6.0 & & \\
\hline \multicolumn{7}{|l|}{ Quality Assurance } \\
\hline \multicolumn{7}{|l|}{ N\&is (HP's etc.) } \\
\hline \multicolumn{7}{|l|}{ Engineering } \\
\hline Projects & & & 15.0 & 30.0 & & \\
\hline Environmental & & & 15.0 & 30.0 & 6.0 & \\
\hline Total man-months & & & 66.0 & 120.0 & 42.0 & \\
\hline Tota! FTE myrs & & & 5.5 & 10.0 & 3.5 & \\
\hline Mater': \& Supplies \$K & & & 10 & 20 & 6 & \\
\hline Travel \$k & & & 10 & 10 & 6 & \\
\hline Subcontracts sK & & & 100 & 500 & & \\
\hline \multicolumn{7}{|l|}{ EG\&G Services SK } \\
\hline \multicolumn{7}{|l|}{ Capital Equipment sK } \\
\hline Total Non-Labor, SK & & & 120 & 530 & 12 & \\
\hline
\end{tabular}




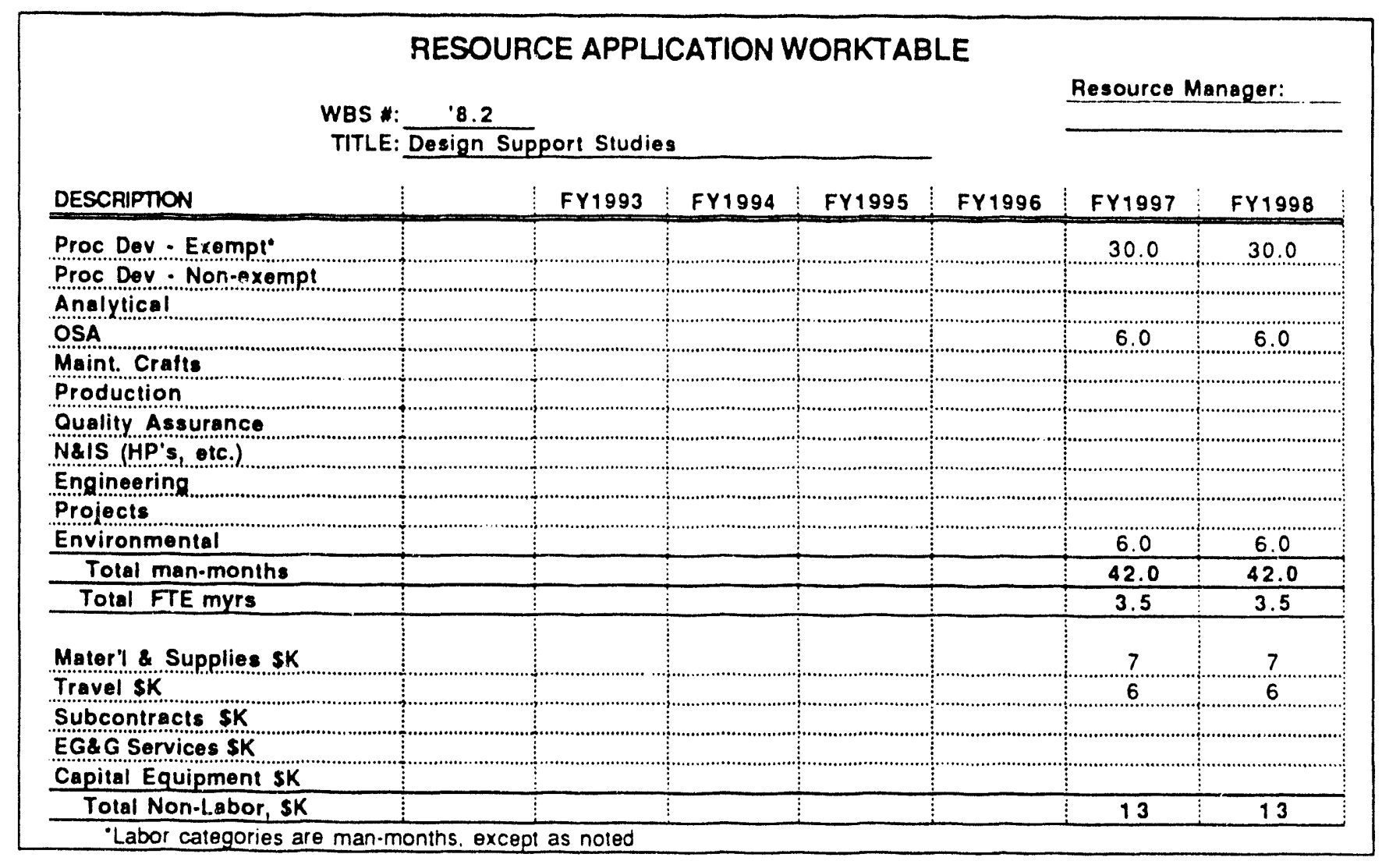




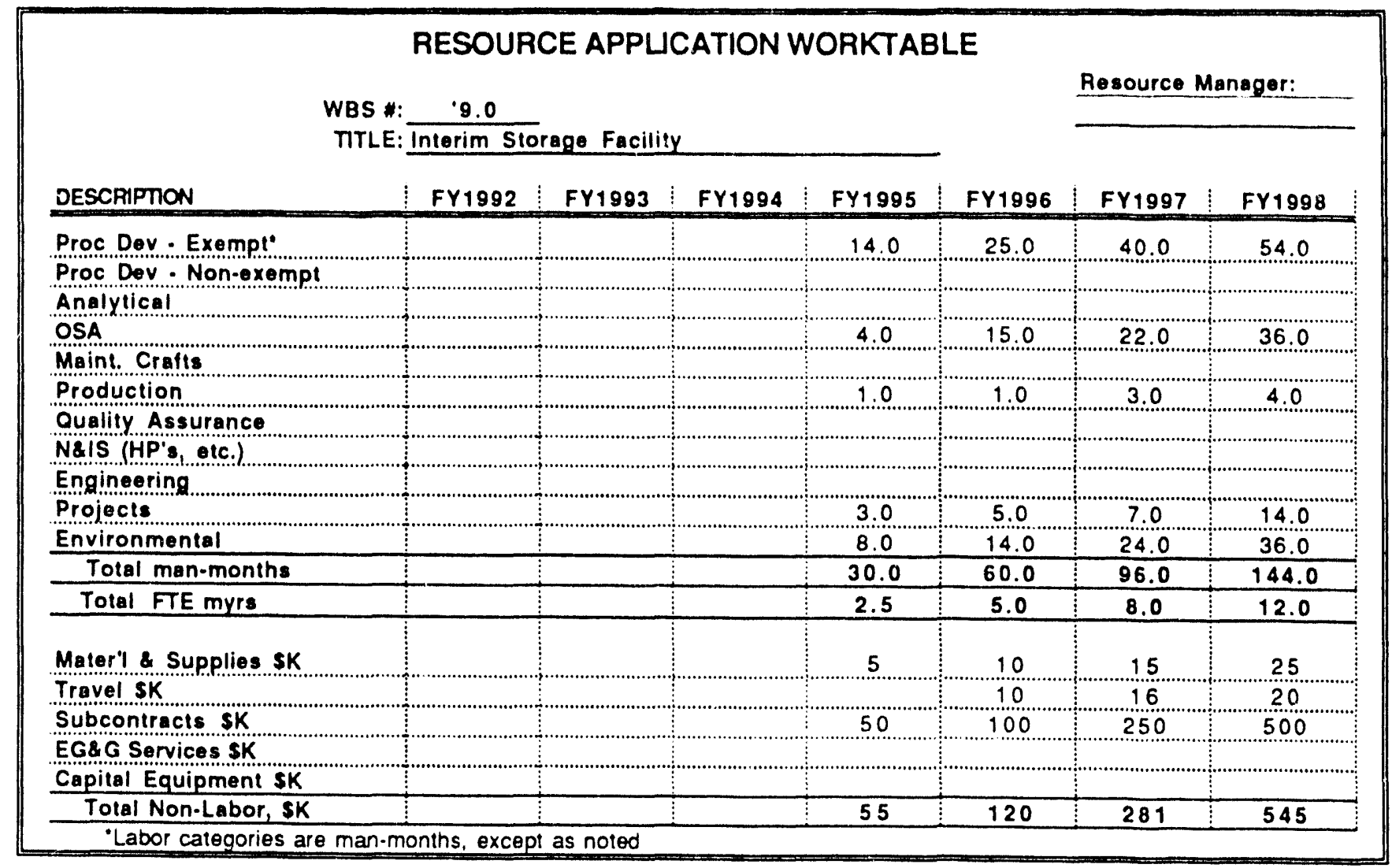

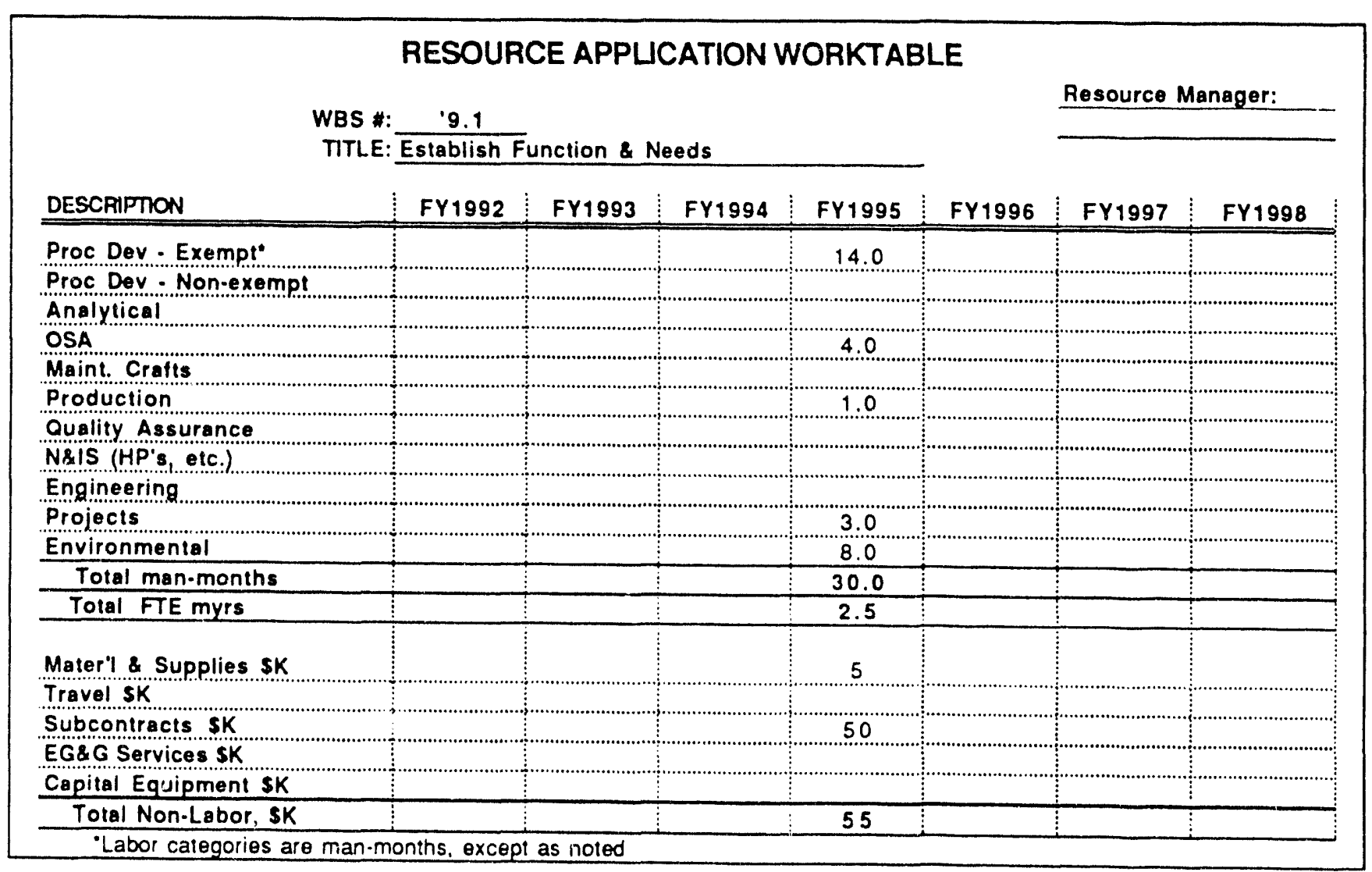




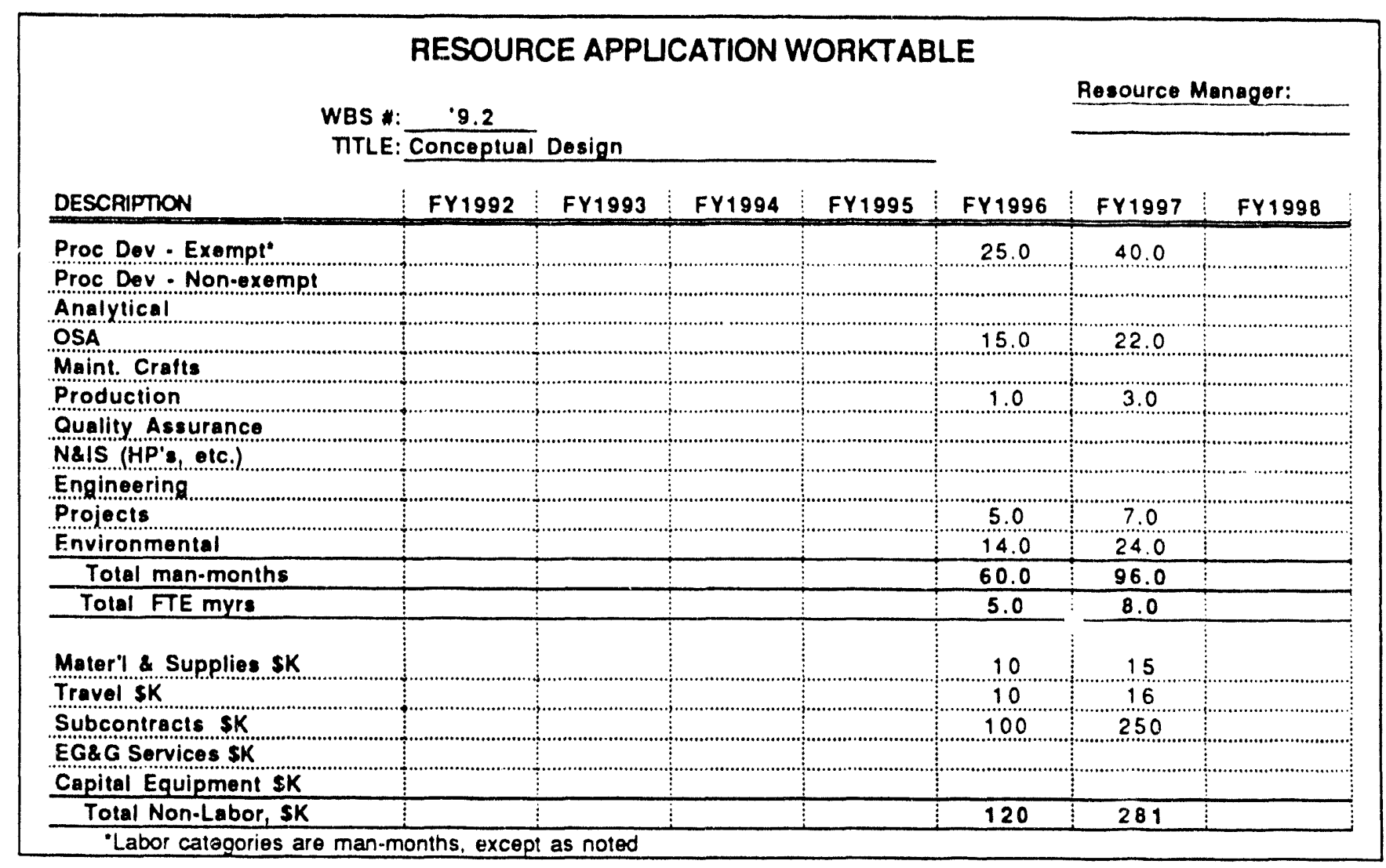

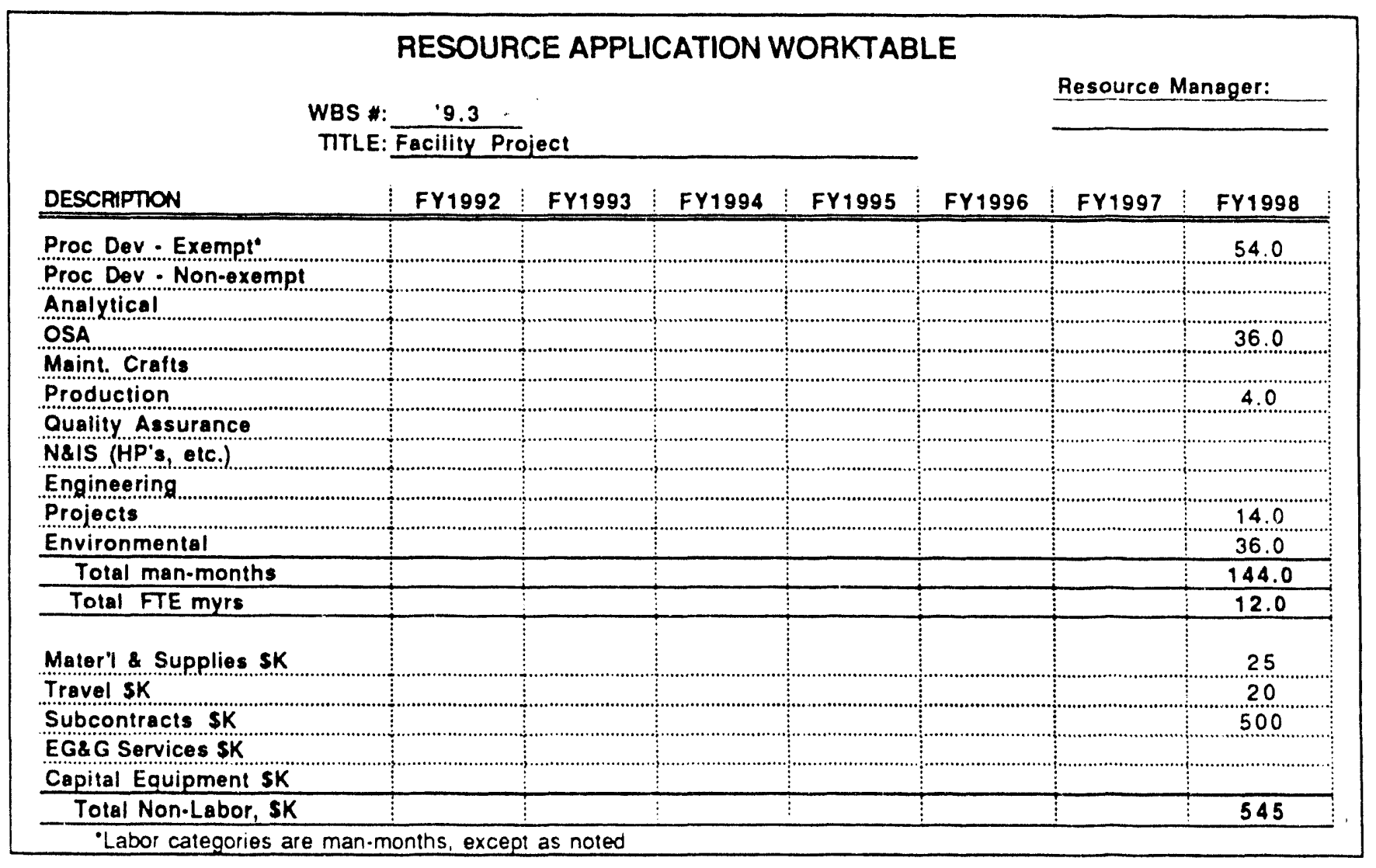



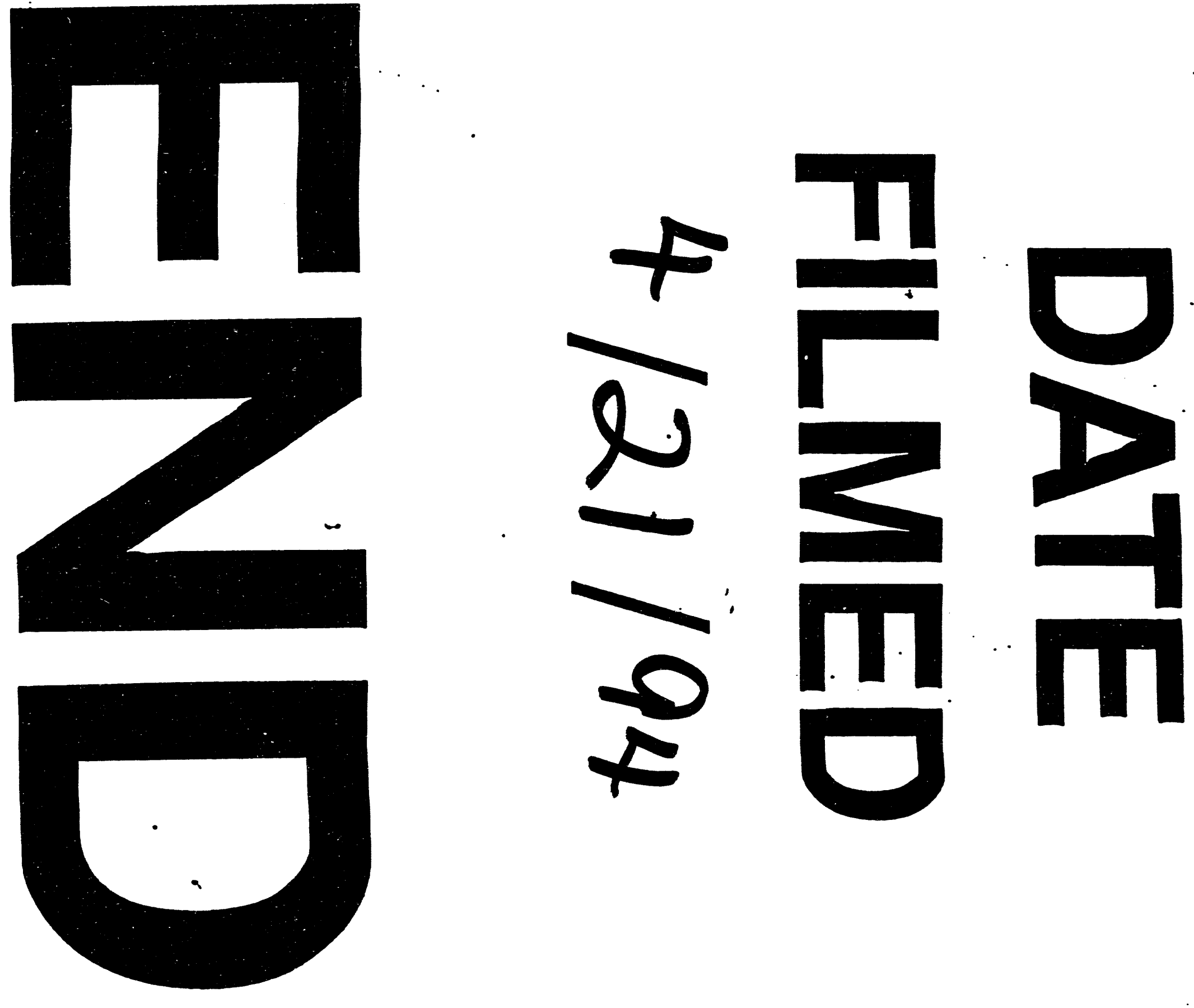
